\title{
A Technology Transfer Plan for the U.S. Department of Energy's Electric Energy Systems Program
}

\author{
B. J. Harrer \\ J. W. Hurwitch \\ L. J. Davis
}

November 1986

Prepared for the U.S. Department of Energy under Contract DE-AC06-76RLO 1830

Pacific Northwest Laboratory

Operated for the U.S. Department of Energy

by Battelle Memorial Institute 


\title{
DISCLAIMER
}

This report was prepared as an account of work sponsored by an agency of the United States Government. Neither the United States Government nor any agency thereof, nor Battelle Memorial Institute, nor any of their employees, makes any warranty, expressed or implied, or assumes any legal liability or responsibility for the accuracy, completeness, or usefulness of any information, apparatus, product, or process disclosed, or represents that its use would not infringe privately owned rights. Reference herein to any specific commercial product, process, or service by trade name, trademark, manufacturer, or otherwise, does not necessarily constitute or imply its endorsement, recommendation, or favoring by the United States Government of any agency thereof, or Battelle Memorial Institute. The views and opinions of authors expressed herein do not necessarly state or reflect those of the United States Government or any agency thereof, or Battelle Memorial Institute.

\author{
PACIFIC NORTHWEST LABORATORY \\ operated by \\ BATTELLE \\ for the \\ UNITED STATES DEPARTMENT OF ENERGY \\ under Contract DE-AC06-76RLO 1830
}

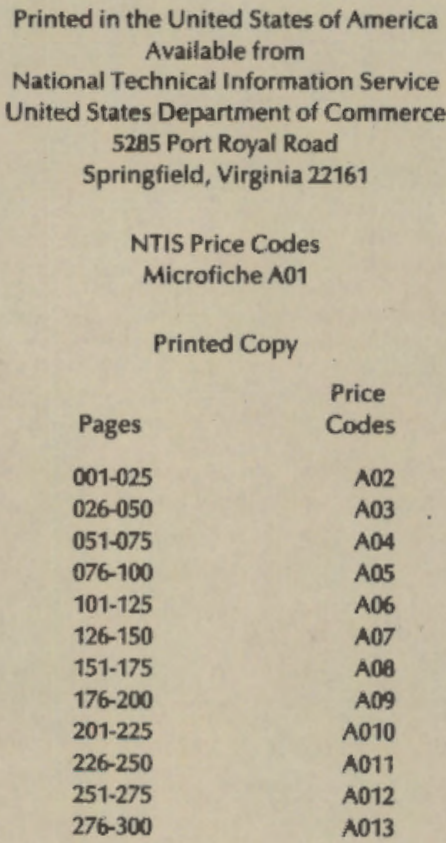


B. J. Harrer

J. W. Hurwitch

L. J. Davis

November 1986

Prepared for

the U.S. Department of Energy

under Contract DE-ACO6-76RLO 1830

Pacific Northwest Laboratory

Richland, Washington 99352 
$\Rightarrow$

$+$

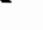

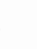




\section{EXECUTIVE SUMMARY}

This report presents a plan for technology transfer activities over the next two years by the Electric Energy Systems (EES) Program in the U.S. Department of Energy (DOE) Office of Energy Storage and Distribution. The report also documents the procedures used in developing the technology transfer plan.

The major objective of this study was to develop a technology transfer plan that would be both practical and effective in promoting the transfer of the products of DOE/EES research to appropriate target audiences. The study drew upon several major components of the marketing process in developing this plan. These components include:

- definition/characterization of the products being produced by the DOE/EES program (i.e. its research projects)

- identification/characterization of possible users of the products being produced by the program (i.e. its target audiences)

- documentation/analysis of the methods currently being used to promote the adoption of DOE/EES products (i.e. its current technology transfer activities)

To define the various research projects within the DOE/EES progran, short descriptions of the program strategies for long-tem research on electric transmission and distribution systems were developed. Brief descriptions of each individual research project within the program were also developed.

The major conclusion that arose from this activity is that the program is extremely broad in terms of its research objectives and the projects it supports. Technology transfer activities must take this diversity into account to be effective. Many of these activities require the participation of the research project managers who are most familiar with their projects.

A characterization matrix was used to characterize the various DOE/EES research projects along two dimensions: 
1. research/development stage (basic research, applied research, exploratory development, engineering development and demonstration)

2. product category (scientific information/technology base, models/ analytical devices and new technology)

One major conclusion reached in this characterization process is that the: DOE/EES program is not primarily a hardware development program. Only about one-quarter of the projects supported by the program are directed towards new technology hardware development, and these projects comprise less than onequarter of the current program budget. The largest percentage of the program's resources, in terms of both number of projects and budget level, is directed towards the development of scientific information and data that provide a base for technology and policy development. Statistics also show that the program is oriented toward early stages of research. Applied research is the predominant stage of research and development category; basic research second in importance and exploratory/engineering development comprises much smaller percentages of both the number of projects and budget level.

Identification of the target audiences for DOE/EES program research highlighted the breadth and depth of the program. The program's target audiences include over 20 distinct groups, ranging from scientific standards complttees to electrical equipment manufacturers. In addition, most of these groups are target audiences for only selected components of the DOE/EES program. Only the Electric Power Research Institute (EPRI) was identified as being a target audience for all components of the program. The diversity of target audiences illustrates the need for selective design and targeting of technology transfer activities.

Documentation and analysis of current DOE/EES technology transfer activities revealed that they include nearly all possible technology transfer methods. The only technology transfer methods that have not been used by some component of the DOE/EES program within the last two years are formal technical assistance/training programs, tax incentives/loan guarantees, and programs to form new spinoff industries. Summarized highlights of these activities include: 
- approximately 190 publications and 130 conference presentations

- hundreds of site visits by technical and industry personnel

- several formal information and cost-sharing agreenents with EPRI and others

- several forums for obtaining industrial feedback on research content

- several personnel transfers, both to and from industry.

After analysis of these activities, it was concluded that no major changes were necessary in the program, particularly at the research program management level. Generally, research managers in the program piace a high priority on performing technology transfer activities, have a good understanding of their target audiences and are often actively sought out by these audiences because of their high level of technical expertise.

The improvements suggested by the analys is of current technology transfer activities are directed towards increasing the visibility of the program within industry and enhancing the ability of the program to deliver concise information on the program to targeted audiences. Despite the best efforts of DOE/EES program managers, it appears that many components of the program are not well known or well understood by their target audiences.

To improve current DOE/EES technology transfer activities, while retaining their positive features, a plan for guiding technology transfer activities over the next two years was developed. In summary, this pian inciudes the following major elements:

- continuation of current technology transfer activities, with more emphasis on increasing the number of publications in industry trade journals and presentations at trade conferences and better overall coordination and documentation

- development of a targeted mailing list for program information

- development and distribution of one-page description sheets for specific research projects 
- development of a systematic process for obtaining industrial input on the overall program and selecting/promoting projects for active transfer through cost sharing, personnel transfers, etc.

- development of annual reports that document the program's technology transfer activities. 


\section{CONTENTS}

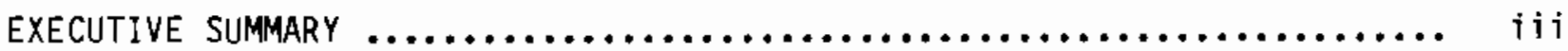

1.0 INTRODUCTION $\ldots \ldots \ldots \ldots \ldots \ldots \ldots \ldots \ldots \ldots \ldots \ldots \ldots \ldots \ldots \ldots \ldots \ldots \ldots \ldots \ldots, 1.1$

2.0 RESULTS AND CONCLUSIONS $\ldots \ldots \ldots \ldots \ldots \ldots \ldots \ldots \ldots \ldots \ldots \ldots \ldots \ldots \ldots, 2.1$

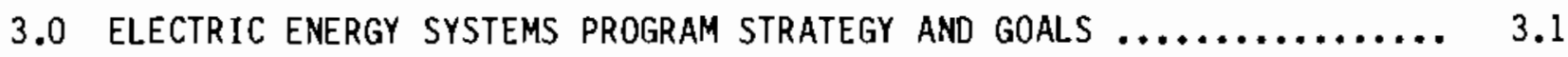

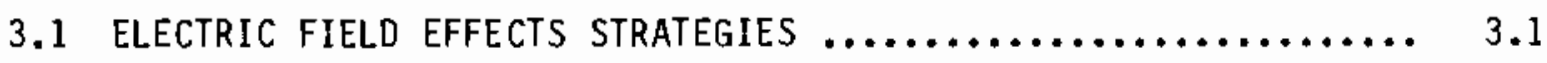

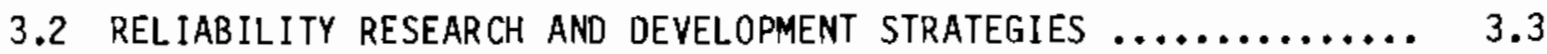

3.2 .1 EMP Impact Anatysis $\ldots \ldots \ldots \ldots \ldots \ldots \ldots \ldots \ldots \ldots \ldots \ldots, 3.4$

3.2.2 Normal/Emergency Operating Concepts ............... 3.5

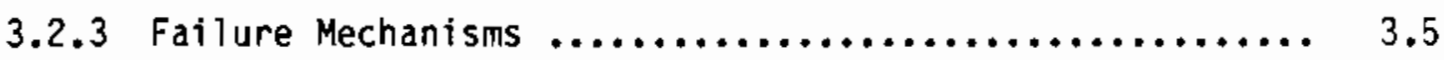

3.3 SYStems technology StRategies $\ldots \ldots \ldots \ldots \ldots \ldots \ldots \ldots \ldots \ldots \ldots, 3.6$

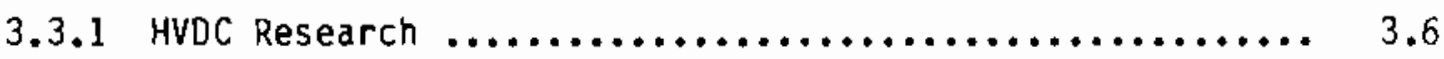

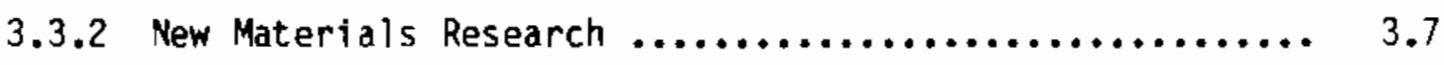

3.3.3 Superconducting Technology $\ldots \ldots \ldots \ldots \ldots \ldots \ldots \ldots \ldots \ldots \ldots \ldots \ldots \ldots, 3.8$

3.3.4 Automation/Processing Concepts $\ldots \ldots \ldots \ldots \ldots \ldots \ldots \ldots, 3.8$

3.3.5 Battery Storage/Load Leveling $\ldots \ldots \ldots \ldots \ldots \ldots \ldots \ldots . . . .6$

3.3.6 Hawaii Deep Water Cable $\ldots \ldots \ldots \ldots \ldots \ldots \ldots \ldots \ldots \ldots \ldots . . .10$

3.4 EES PROGRAM TECHNOLOGY TRANSFER NEEdS $\ldots \ldots \ldots \ldots \ldots \ldots \ldots \ldots \ldots . .10$

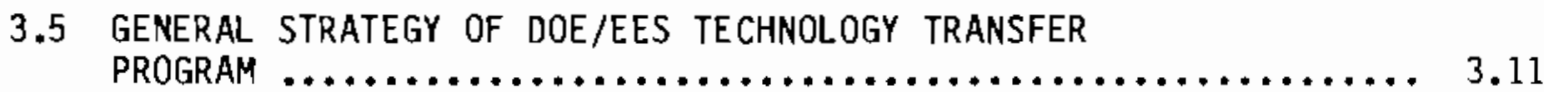

4.0 ElECTRIC ENERGY SYSTEMS PROJECT CHARACTERIZATIONS $\ldots \ldots \ldots \ldots \ldots \ldots . . . .$.

4.1 Characterization variable definitions $\ldots \ldots \ldots \ldots \ldots \ldots \ldots \ldots, 4.1$

4.2 DOE/EES PROJECT Characterizations $\ldots \ldots \ldots \ldots \ldots \ldots \ldots \ldots \ldots \ldots . . .1$

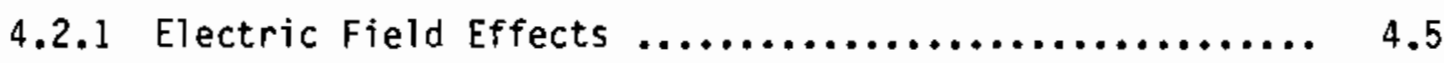

4.2 .2 EMP Impact Analysis $\ldots \ldots \ldots \ldots \ldots \ldots \ldots \ldots \ldots \ldots \ldots, 4.6$ 
4.2.3 Norma1/Emergency Operating Concepts ................ 4.5

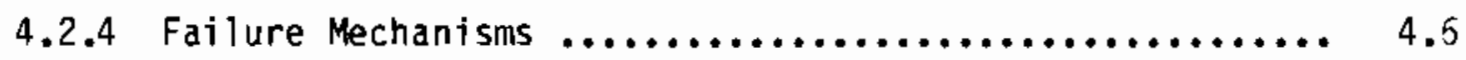

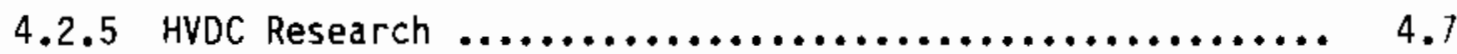

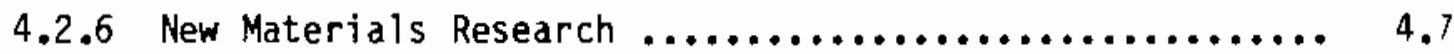

4.2.7 Superconducting Technology $\ldots \ldots \ldots \ldots \ldots \ldots \ldots \ldots \ldots \ldots, 4.3$

4.2.8 Automation/Processing Concepts ................... 4.3

4.2.9 Battery Storage/Load Leveling Research ............ 4.3

4.2.10 Hawaii Deep Water Cable .......................... 4. 3

5.0 TARget AUdienCES AND tRANSFER MEChanismS fOR EES PROGRAMS $\ldots \ldots \ldots \ldots .5 .1$

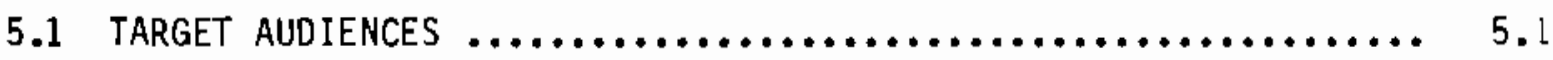

5.1 .1 Target Audience Identification $\ldots . \ldots \ldots \ldots \ldots \ldots \ldots \ldots . . .6 .1$

5.1.2 Target Audience Characteristics ................... 5.t

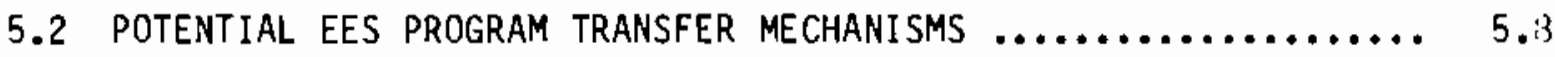

6.0 CURRENT EES TECHNOLOGY TRANSFER ACTIVITIES AND SUGGESTED

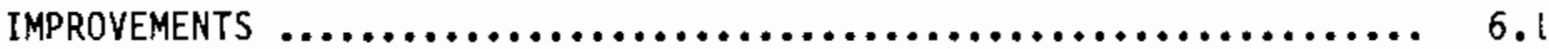

6.1 REVIEW OF DOE/EES TECHNOLOGY TRANSFER ACTIVITIES OVER

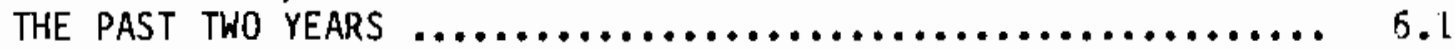

6.1.1 Electric Field Effects Technology Transfer

Activities $. . \ldots \ldots \ldots \ldots \ldots \ldots \ldots \ldots \ldots \ldots \ldots \ldots \ldots \ldots \ldots, 6.2$

6.1.2 EMP Technology Transfer Activities ................ 6.4

6.1.3 Normal/Emergency Operating Concepts Technology Transfer Activities ........................... 6.5

6.1.4 Failure Mechanisms Technology Transfer Activities ...... 6.5

6.1.5 HVDC Technology Transfer Activities ................ 6.6

6.1.6 Automation/Processing Concepts Technology

Transfer Activities ............................ 6.?

6.1.7 New Materials Technology Transfer Activities .......... 6.8

6.1.8 Superconducting Technology Transfer Activities ....... 6.10 
6.1.9 Battery Storage/Load Leveling Research Technology Transfer Activities ............................. 6.10

6.1.10 Hawaij Deep Water Cable Technology Transfer Activities .................................... 6.11

6.2 SUMMARY OF DOE/EES PROGRAM TECHNOLOGY TRANSFER ACTIVITIES $\ldots \ldots \ldots \ldots \ldots \ldots \ldots \ldots \ldots \ldots \ldots \ldots \ldots \ldots \ldots \ldots \ldots \ldots \ldots, 6.12$

6.3 SUGGESTED IMPROVEMENTS IN CURRENT TECHNOLOGY TRANSFER ACTIVITIES $\ldots \ldots \ldots \ldots \ldots \ldots \ldots \ldots \ldots \ldots \ldots \ldots \ldots \ldots \ldots \ldots \ldots \ldots, 6.12$

7.0 DOE/EES PROGRAM TECHNOLOGY TRANSFER PLAN FOR THE NEXT TWO

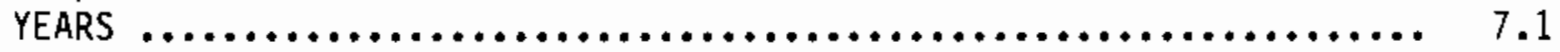

7.1 TASK ASSIGNMENTS FOR EES PROGRAM TECHNOLOGY TRANSFER

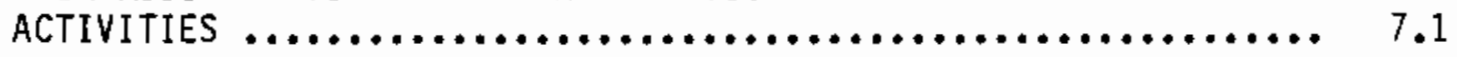

1.2 SUMMARY OF PLANNED EES PROGRAM TECHNOLOGY TRANSFER

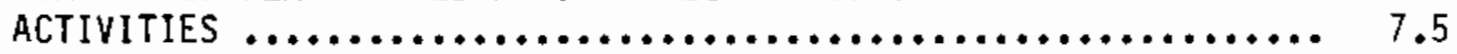

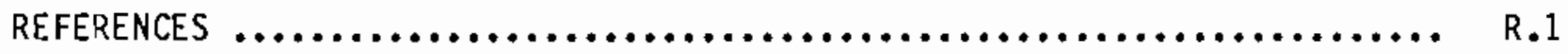

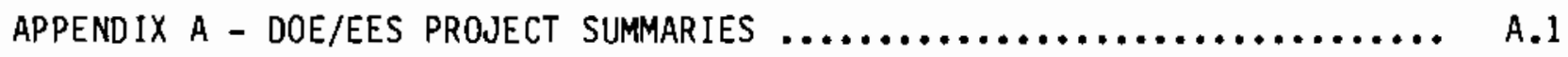

APPENDIX B - DOE/EES PROJECT CHARACTERIZATION MATRICES $\ldots \ldots \ldots \ldots \ldots \ldots$ B. 1

APPENDIX $C$ - QUESTIONNAIRE USED IN GATHERING INFORMATION ON TECHNOLOGY TRANSFER ACTIVITIES OF DOE/EES PROGRAM......... C.1

APPENDIX D - DOE/EES PROGRAM MAJOR PUBLICATIONS AND CONFERENCE PRESENTATIONS IN 1985-1985 
.

\author{
.
}

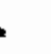




\section{FIGURES}

2.1 Overall EES Program Characterization Sumary .................. 2.3

2.2 Electric Field Effects Characterization Summary ................ 2.5

2.3 Reliability Research Characterization Sumary ................ 2.6

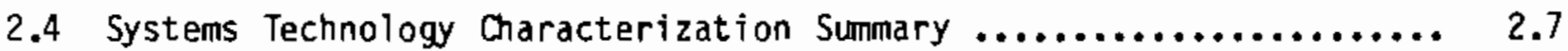

6.1 Composition of Typical Electric Field Effects Distribution ........ 6.3

6.2 Composition of Typical Automation/Processing Concepts

Distribution ....................................... 6.8

6.3 Composition of Typical New Materials Distribution ................ 6.9 


\section{TABLES}

2.1 Matrix Used to Characterize Research Projects $\ldots . \ldots \ldots \ldots \ldots \ldots \ldots .2 .2$

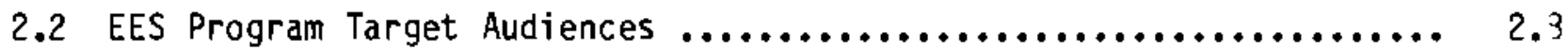

2.3 DOE/EES Technology Transfer Activities Over

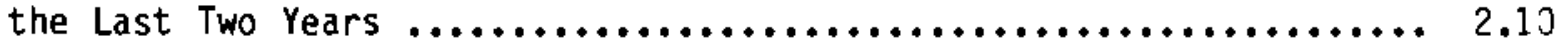

2.4 Centralized Technology Transfer Activities for

DOE/EES Program Over the Next Two Years $\ldots \ldots \ldots \ldots \ldots \ldots \ldots \ldots \ldots \ldots .2 .12$

2.5 Project Level Technology Transfer Activities for Electric

Field Effects, EMP and Hawaii Deep Water Cable .................. 2.13

2.6 Project Level Technology Transfer Activities for

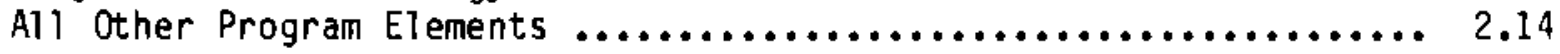

4.1 Matrix Used to Characterize Research Projects .................. 4.2

4.2 Number of EES Projects Characterized into Each Stage of

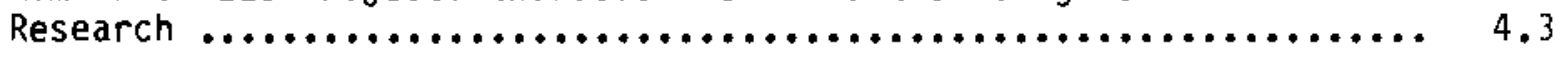

4.3 EES Program Stage of Research Budget Allocation Summary .......... 4.4

4.4 Number of EES Projects Characterized Into Each Technology

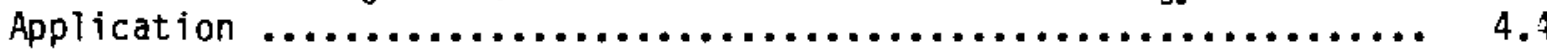

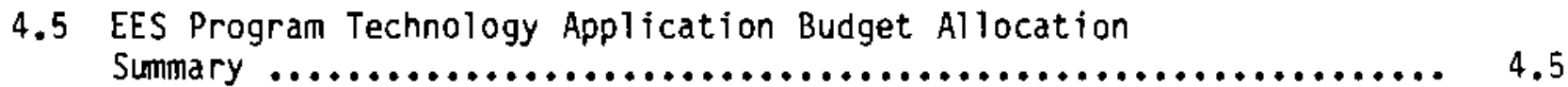

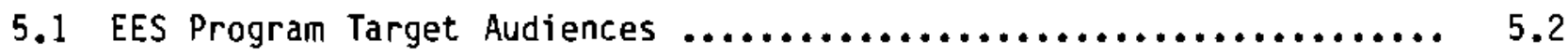

5.2 Comparative Advantages of Technology Transfer Mechanisms

Ordered from Most Passive to Most Active ..................... 5.11

6.1 DOE/EES Technology Transfer Activities in 1984 and $1985 \ldots \ldots \ldots \ldots 6.13$

7.1 Summary of Technology Transfer Plan for DOE/EES Program

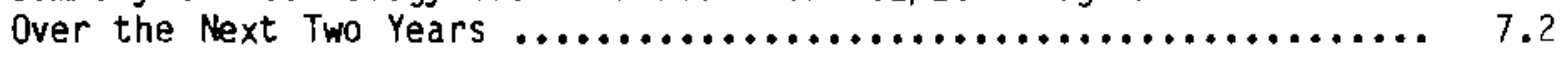

7.2 Critical Paths for Selected DOE/EES Technology Transfer Activities from $10 / 1 / 86$ to $10 / 1 / 87$ 


\subsection{INTRODUCTION}

The Electric Energy Systems (EES) Program in the Office of Energy Storage and Distribution of the U.S. Department of Energy (DOE) provides support for research and development intended to solve mid- to long-term problems associated with electric energy generation, transmission and distribution. The major emphasis of the program is on transmission and distribution components, and excludes research and development related to conversion (i.e., nuclear, fossil or end-use technologies). The projects supported by DOE/EES are intended to provide a sustained long-term commitment to reducing the cost, improving the reliability, and maintaining the safety of tr.e nation's electrical transmission and distribution system. Efforts are concentrated in areas not previously provided by any individual utility, group of utilities, or research arm of the electric utility industry.

The research performed under the sponsorship of the DOE/EES program can be broadly separated into three categories:

- electric field effects research

- reliability research and development

- systems technology research.

The research being conducted in each of these categories is intended to provide technologies and/or information that will lead to the solution of mid- to longterm problems associated with construction and operation of the nation's electrical transmission and distribution system.

Electric field effects research is aimed at developing an objective body of information on the impacts of electric and magnetic fields on biological processes. This information is intended to eventually provide input to the development of standards for exposure to these fields by appropriate regulatory bodies, such as state environmental agencies, that can be applied in the siting, design and operation of electrical transmission and distribution systems. These standards will provide a consistent set of criteria that are intended to protect human and/or animal health and avoid unnecessary costs to electric utilities. 
It is generally not productive for utilities and their research facilities to perform their own research on electric field effects because such research is often regarded as biased. The DOE/EES electric field effects research program provides a means of assessing the complex issues associated with electric and magnetic field effects in an objective fashion. The electric field effect:; program includes research in the following major subcategories:

- biological research--alternating current

- biological research--direct current.

The purpose of the reliability research and development program is to support the development of an electrical network that will enhance regional energ. exchanges, optimize control of all electric energy sources, and enhance essential electric service continuity, especially during emergencies. Reliability research and development includes the following major subcategories:

- normal/emergency operating concepts

- failure mechanisms

- electromagnetic pulse (EMP) impact analysis.

Research is being conducted into new control concepts for improving electric power continuity during periods of emergency and normal operation. Power outages can impose significant economic costs on both utilities and their customers. If the frequency and impacts of these outages can be reduced through better control procedures and equipment, outage costs can be reduced. Many of these concepts involve the use of computer-aided power system control technologies. Research into the causes of failure of electrical insulating materials is also part of reliability research and development.

Reliability research and development has also emphasized estimating the impacts on electric transmission and distribution systems of electromagnetic pulses that may result from high-altitude nuclear explosions. After these impacts have been evaluated, appropriate strategies for reducing the-vulnerability of electric systems to such explosions can be developed.

The purpose of the systems technology program is to provide advanced concepts, materials, and systems to obtain significant improvements in transmission and distribution system operating efficiencies. Such improvements will 
lead to better resource utilization and lower fuel usage in electricity production. Both utilities and their customers will benefit from improvements in transmission and distribution system operating efficiencies that will reduce the total delivered cost of electricity.

The efficient operation of electric transmission and distribution systems is becoming more complex, as generation becomes more decentralized and power markets more competitive. New materials and operating systems that are being developed and tested as part of the systems technology program promise to improve operating efficiency and reduce system energy losses. Utilities must build and maintain fossil-fuel fired generating units to meet the peak or maximum demands that occur on their systems. Techniques being developed to better manage peak demands and store energy to meet these demands could reduce the need for these high-cost generating units. Systems technology includes research in the following major subcategories:

- high-voltage direct current (HVDC)

- new materials

- superconducting technology

- automation/processing concepts

- battery storage/load leveling

- Hawai deep water cable.

This chapter has provided a brief overview of the major components of the DOE/EES research program. The program is broad in scope and its research is generally intermediate to long-term in nature. The research is designed to complement, but not replace, the research activities of the Electric Power Research Institute (EPRI), individual utilities, equipment manufacturers and others that is generally more short-term in nature.

The benefits of the DOE/EES program research and development will only be realized if the results are transferred to the people capable of affecting the nation's electrical transmission and distribution system. This report is intended to provide a framework for efforts to transfer technologies and information developed in the DOE/EES program to appropriate audiences. Such efforts have been conducted by various elements of the program for a number of years, 
but this is the first attempt to organize and document the program's efforts in conjunction with the DOE's requirements for technology transfer planning.

This report is divided into seven chapters. Chapter 2.0 presents the results and conclusions of our initial efforts to organize and characterize the technology transfer efforts of the DOE/EES program. Included in Chapter 2.0 is a summary of the technology transfer strategies and activities that are planned for the program in the next two years. A detailed overview of the DOE/EES program that describes how the program is designed to meet the intermediate and long-term research needs of the nation's transmission and distribution system, is presented in Chapter 3.0. Chapter 4.0 characterizes the various types of OOE/EES projects in terms of their appropriate target audiences and appropriate means of technology transfer. Chapter 5.0 discusses the target audiences for DOE/EES research projects and presents general information on various types of technology transfer mechanisms.

Chapter 6.0 describes the current technology transfer activities associated with DOE/EES research. This information was developed through a series 0 = field interviews with various DOE/EES project managers. Actions that could improve existing technology transfer efforts in the DOE/EES program are also presented in Chapter 6.0 .

The final chapter of the report presents specific technology transfer activities proposed for the next two years of the OOE/EES program. This description will identify the individuals responsible for managing the various activities, a schedule for the activities, and projected resource requirements for conducting the activities. 


\subsection{RESULTS AND CONCLUSIONS}

Six major activities were conducted to document and analyze the technology transfer activities within the DOE/EES program:

- definition of the program's research, its needs and objectives

- characterization of the individual research projects within the program, their stages of research and types of application

- identification/characterization of target audiences for the program's research and potential technology transfer mechanisms for reaching these audiences

- description of current technology transfer activities within the program

- analysis of suggested improvements in current activities

- development of a technology transfer plan to guide transfer activities over the next two years.

To define DOE/EES program research, the research needs that the program is designed to meet and the various elements of the program attempting to meet these needs were analyzed. Short summaries of each research project within the program were developed and are presented in Appendix $A$.

The most evident feature of the EES program is the breadth and depth of its research mission. The program conducts research designed to improve the safety, reliability and economics of the nation's electrical transmission and distribution system. However, within the context of these basic goals, over 70 research projects are conducted ranging from basic research on the effects of electric fields on biological systems to engineering development of superconducting equipment.

To further define the types of DOE/EES program research, a matrix for characterizing each research project by research stage and technology type was developed and used. This matrix is illustrated in Table 2.1. Knowledgeable research managers from within the DOE/EES program were then asked to describe 


\section{TABLE 2.1. Matrix Used to Characterize Research Projects}

\begin{tabular}{|l|l|l|l|l|l|}
\hline $\begin{array}{l}\text { Technology } \\
\text { Application }\end{array}$ & $\begin{array}{c}\text { Stage of R\&D } \\
\text { Research }\end{array}$ & $\begin{array}{c}\text { Applied } \\
\text { Research }\end{array}$ & $\begin{array}{c}\text { Exploratory } \\
\text { Development }\end{array}$ & $\begin{array}{c}\text { Engineering } \\
\text { Development }\end{array}$ & Demonstration \\
\hline \hline $\begin{array}{l}\text { Scientific } \\
\text { Information/ } \\
\text { Technology Base }\end{array}$ & & & & & \\
\hline $\begin{array}{l}\text { Models and } \\
\text { Analytical Devices }\end{array}$ & & & & & \\
\hline New Technology & & & & & \\
\hline
\end{tabular}

Stages of R\&D:

1. Basic Research - Basic investigation including all effort toward increased knowledge of natural phenomena, solution of problems in various sciences, and identification of new technological concepts.

2. Applied Research - Extension of basic research whereby the specific application of increased knowledge is envisioned, may include some preliminary design toward practical solutions.

3. Exploratory Development - Solution of specific problems short of major development projects, exploring such problem areas with a view toward developing solutions; early concept formulation efforts.

4. Engineering Development - More mature development of hardware and systems being engineered for service use, but not yet ready for commercial operation.

5. Demonstration - Use of hardware and systems in a prototype commercial operation.

Fesearch Applications:

1. Scientific Information/Technology Base. The ultimate product of the research is information and data that can be used in making policy decisions, evaluating products, or testing theories.

2. Models and Analytical Devices - The result of the research is a device/tool that can be used in conducting further research or a model that can be used in research and/or commercial application.

3. New Technology - Equipment or components that can be used in commercial applications.

the individual projects within their area of expertise in terms of the characteristics shown in Table 2.1 .

Characterizations of the total DOE/EES program are presented in Figure 2.1. The majority of the current projects and the majority of the current 
Technology Application Summary
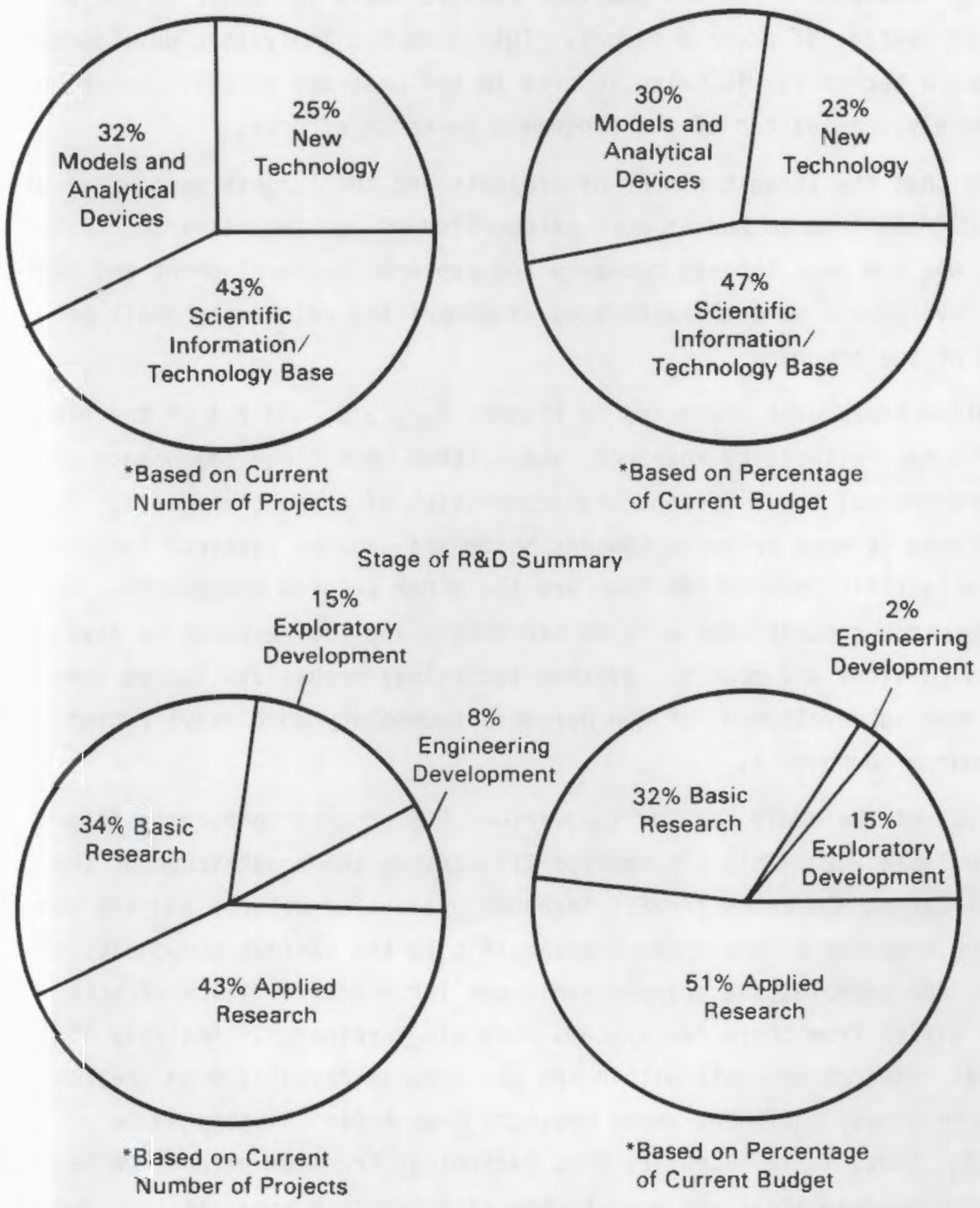

FIGURE 2.1. Overal1 EES Program Characterization Summary 
budget in the EES program were aimed at the development of scientific information and data that provide a base for technology and policy development. Analytical devices and models was the next largest area of research, and new technology development was the smallest research area in number of projects and current percentage of program budget. This does not imply that development of new hardware technology is being ignored in the program; it still comprises approximately one-quarter of the program's research efforts.

Note that the largest number of projects and the largest percentage of the current DOE/EES program budget were categorized as applied research. Basic research was the next largest category and exploratory development and engineering development were characterized as comprising relatively small percentages of the program.

Similar breakdowns presented in Figures 2.2, 2.3, and 2.4 of the electric field effects, reliability research, and systems technology components of the EES program reveal the different characteristics of these components. Electric field effects is more oriented towards basic and applied research intended to develop scientific information than are the other program components. Reliability research concentrates more on performing applied research to develop analytical devices and models. Systems technology emphasizes the exploratory and engineering development of new hardware technology more heavily than do the other program components.

A list of the audiences for the various EES program components is presented in Table 2.2. This information illustrates the broad scope of the potential target audiences for EES technology transfer efforts and the need for developing transfer efforts that are specific to the various components of the program. For example, the primary audiences for electric fields effects research differ from those for systems technology research. Analysis of the individual research projects within the EES program revealed even greater differences in target audiences among projects than those illustrated in Table 2.2. Thus, it is necessary that technology transfer efforts be tailored to specific program areas and even to specific research projects in order to maximize the effectiveness of such efforts. 


\section{Technology Application Summary}
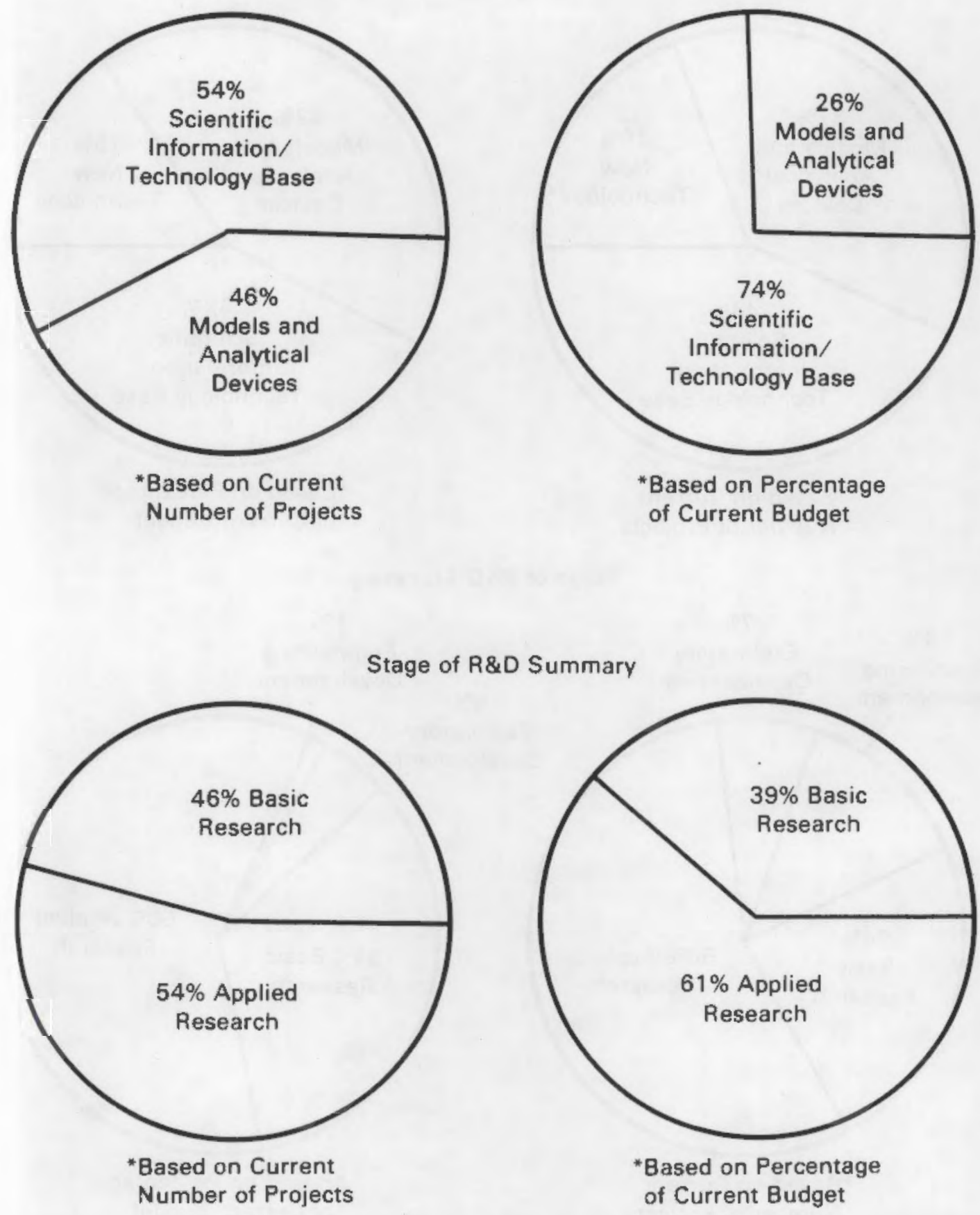

FIGURE 2.2. Electric Field Effects Characterization Summary 
Technology Application Summary
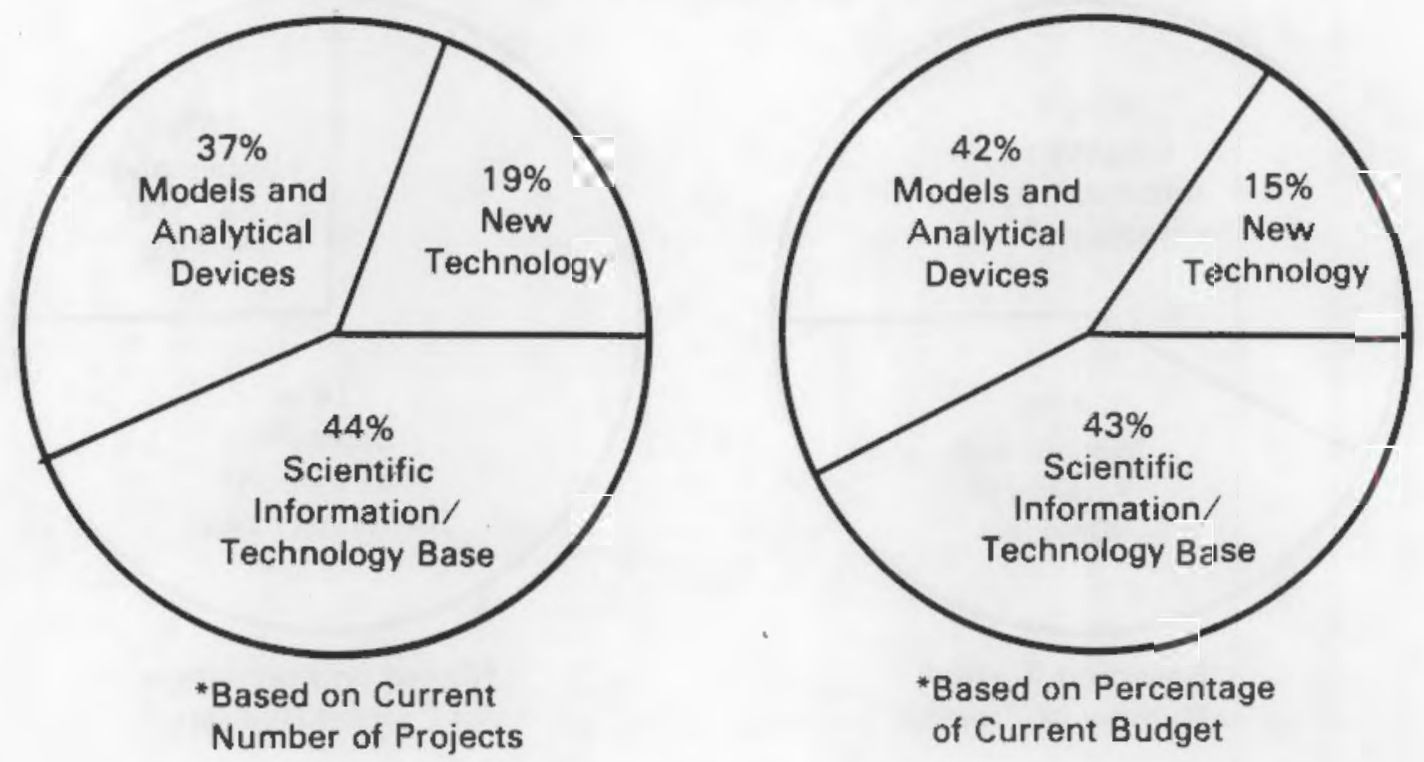

Stage of R\&D Summary
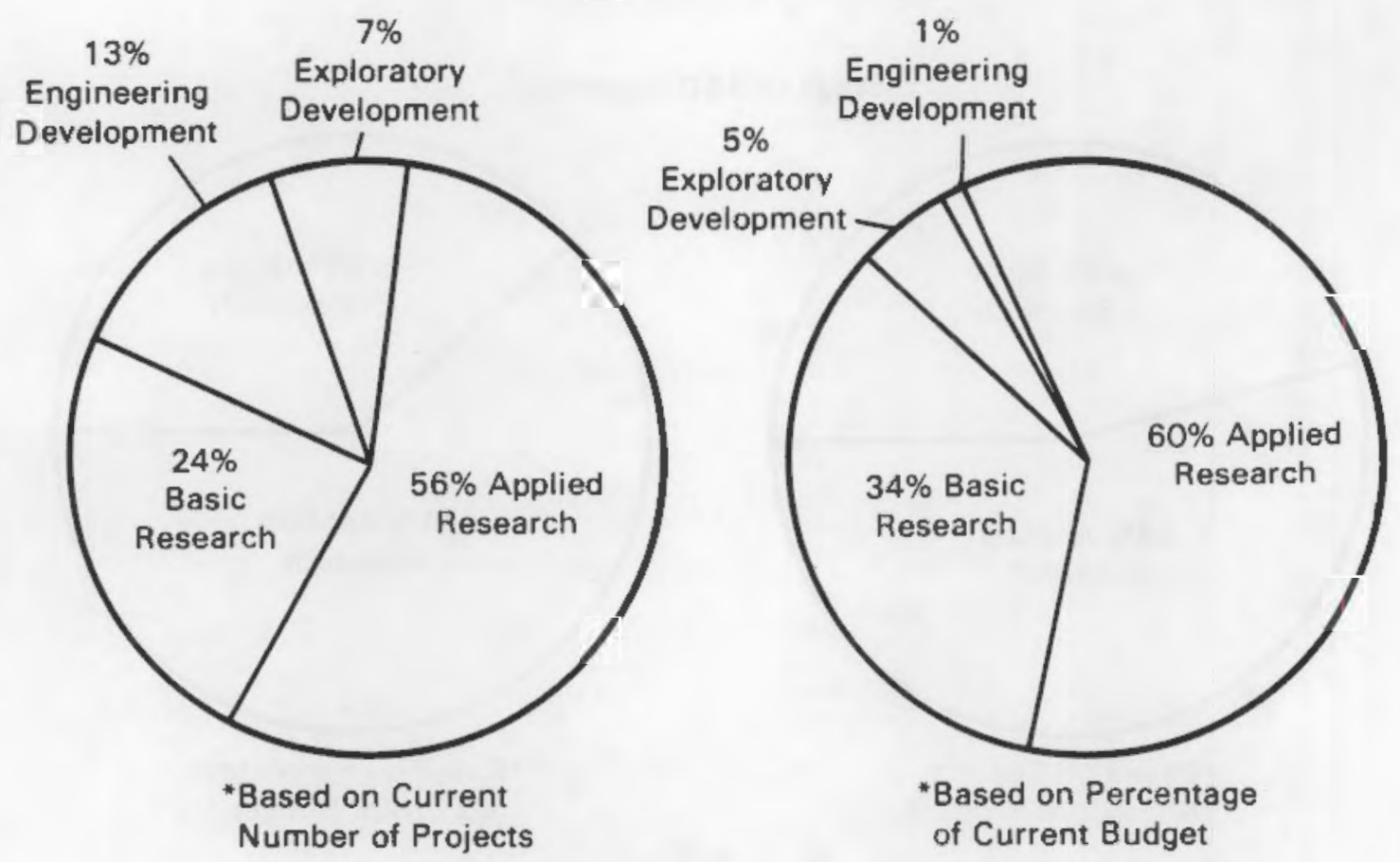

FIGURE 2.3. Reliability Research Characterization Summary 

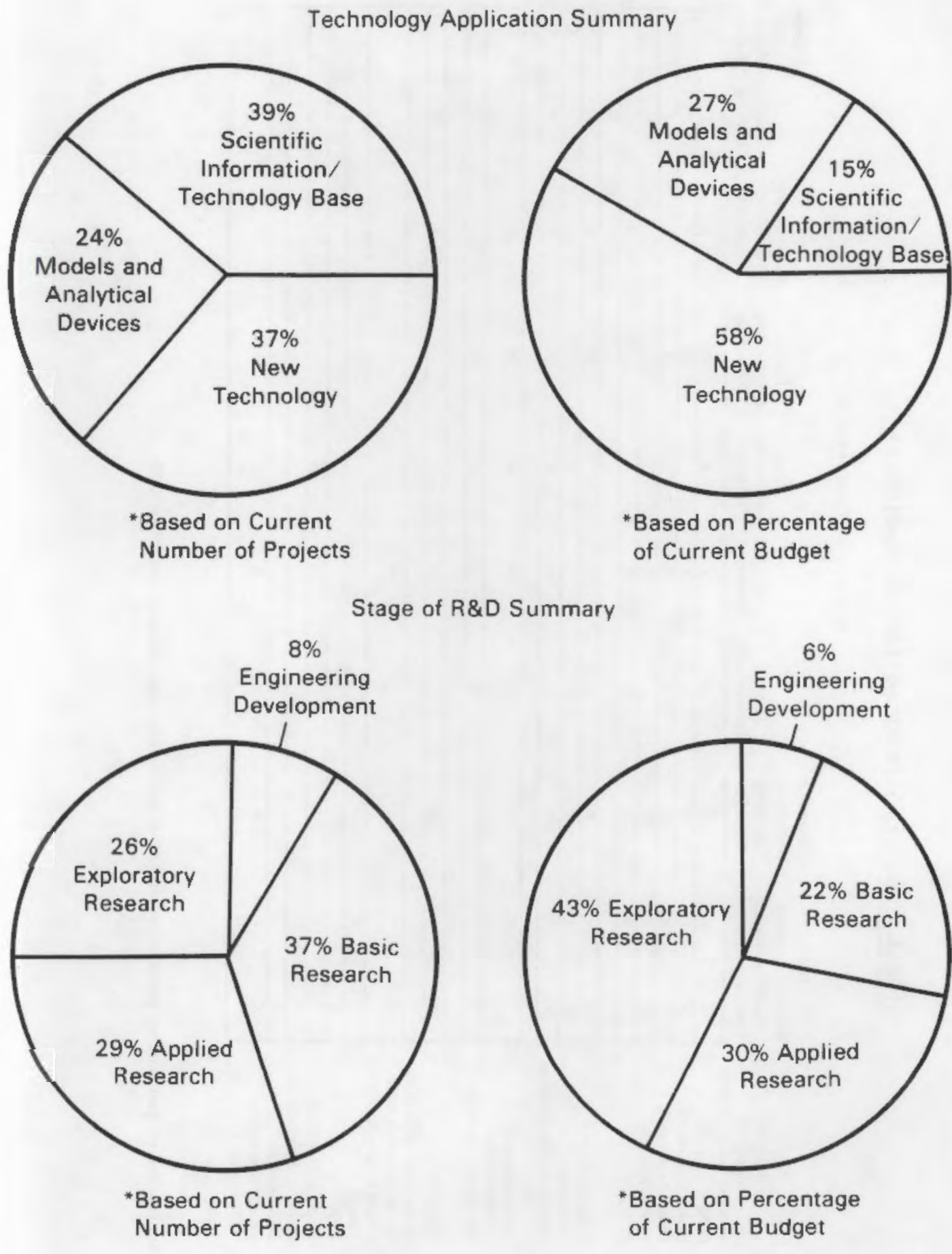

FIGURE 2.4. Systems Technology Characterization Sumnary 


\section{TABLE 2.2. EES Program Target Audiences}

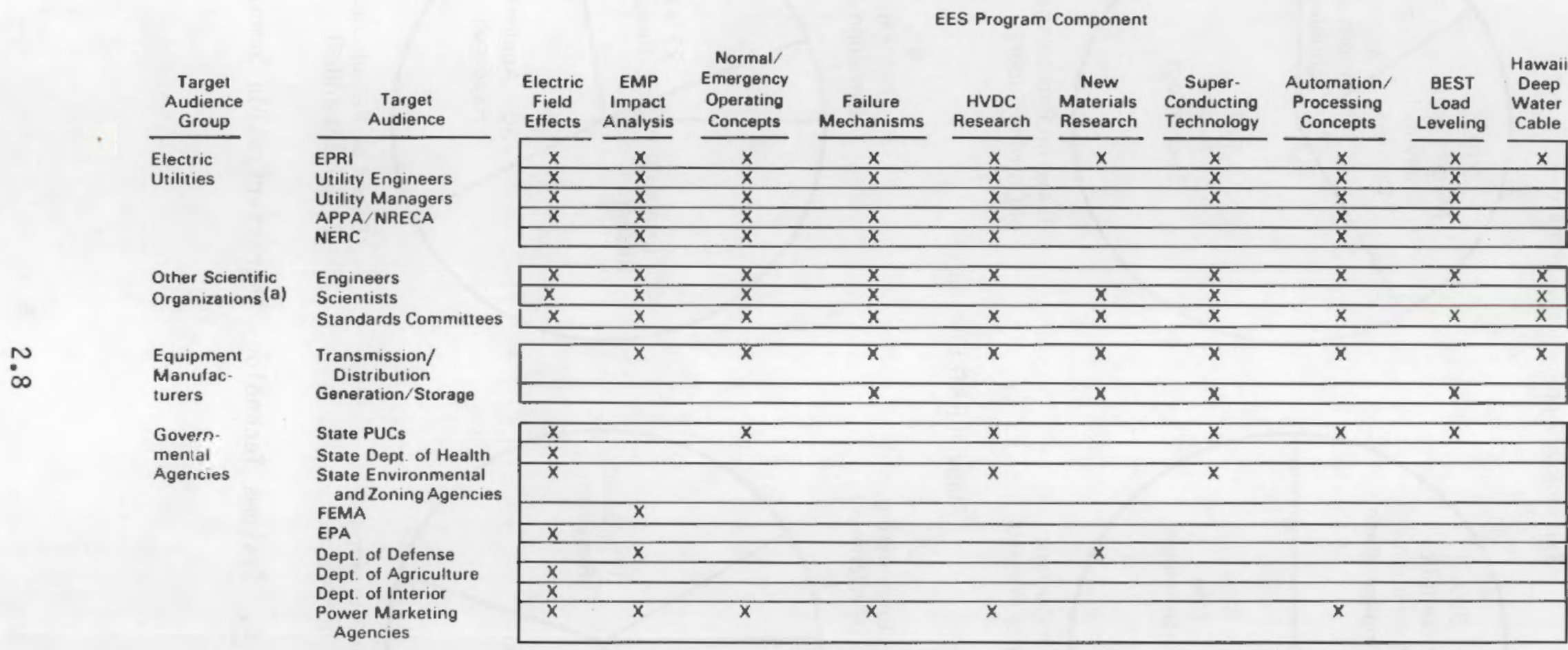

(a) Includes private research organizations, universities and other publicly funded research organizations. 
The assessment of the technology transfer activities within the EES program over the past two years revealed that the program already contains an extensive technology transfer component. These activities are identified in Table 2.3 by program area. Highlights of current activities include:

- approximately 190 publications in 1984 and 1985, over 90\% in technical/professional journals or proceedings

- approximately 130 conference presentations

- hundreds of site visits by technical and industry personnel to such facilities as the Battery Energy Storage Test (BEST) facilities, the Athens Automation and control project, and the electric field effects laboratories.

- several formal information and cost-sharing agreements with EPRI, other utility research and development groups [i.e. Empire State Electric Energy Research Corporation (ESEERCO)], state agencies and international organizations

- several forums for industrial feedback on research content

- several temporary personnel transfers, either to or from industry. In general, the activities conducted are consistent with both the characteristics of the various research components of the EES program and the target audiences for this research. For example, the electric field effects program has concentrated its technology transfer activities on technical publications. This is appropriate because the emphasis of this program is on developing basic and applied information for professional scientists and government agencies. The systems technology program has emphasized joint development and/or testing with industry, because it is more oriented towards the exploratory and engineering development of hardware. The EES research program managers know the primary audiences for their research, and an analysis of several distribution lists for research reports revealed that managers are effective in directing their reports to appropriate target audiences.

The analysis of the current technology transfer activities and current program resource constraints suggests that improvements in the program should 
TABLE 2.3. DOE/EES Technology Transfer Activities in 1984 and 1985

Publications

2. Information Interactions

3 Media or Trade Literature

4. Data Banks

5 Information Dissemination Centers

6. Technical Meetings Exchanges(c)

7. Direct Mailing

8. Liaison with Industry Associations

9. Workshops Conferences Seminars

10 Formal Visits

11 Industry Review Group

12. Intergovernment Agency Agreements

13. Agreements with A\&D Arm of Public Utility Industry

14. International Agreements

15. Personnel Transfer to from Industry

16. Government Development Joint Test

17. Joint Government/Industry Development and Test

18. Spinoft Technology Development $(\mathrm{c})$

\begin{tabular}{|c|c|c|c|c|c|c|c|c|c|}
\hline $\begin{array}{l}\text { Total } \\
\text { Program }\end{array}$ & $\begin{array}{l}\text { Electric } \\
\text { Fieid } \\
\text { Elfects }\end{array}$ & $\begin{array}{c}\text { EMP } \\
\text { Impact } \\
\text { Analysis }\end{array}$ & $\begin{array}{c}\text { Normal/ } \\
\text { Emergency } \\
\text { Operating } \\
\text { Concepts }\end{array}$ & $\begin{array}{c}\text { Failure } \\
\text { Mechanisms }\end{array}$ & $\begin{array}{c}\text { HVDC } \\
\text { Research }\end{array}$ & $\begin{array}{c}\text { New } \\
\text { Materials } \\
\text { Pesearch }\end{array}$ & $\begin{array}{c}\text { Super- } \\
\text { Conducting } \\
\text { Technology }\end{array}$ & $\begin{array}{c}\text { Automation } \\
\text { Processing } \\
\text { Concepts }\end{array}$ & $\begin{array}{l}\text { BEST } \\
\text { Load } \\
\text { Leveling }\end{array}$ \\
\hline
\end{tabular}

\begin{tabular}{|c|c|c|c|c|c|c|c|c|c|}
\hline$x$ & $x$ & $x$ & $x$ & $x$ & $x$ & $x$ & $x$ & $x$ & $x$ \\
\hline$x$ & $x$ & $x$ & $x$ & $x$ & $x$ & $x$ & $x$ & $x$ & $x$ \\
\hline$x$ & $x$ & & $x$ & & $x$ & & $x$ & $x$ & $x$ \\
\hline
\end{tabular}

$x$

$x^{(b)}$

$\begin{array}{llllllll}x & x & x & x & x & x & x & x\end{array}$

\begin{tabular}{|c|c|c|c|c|c|c|c|c|c|c|}
\hline$x$ & & & & & & & & & & \\
\hline$x$ & $x$ & & $x$ & & & $x$ & $x$ & $x$ & $x$ & \\
\hline$x$ & $x$ & $x$ & & $x$ & $x$ & $x$ & $x$ & $x$ & $x$ & \\
\hline$x$ & $x$ & & & & $x$ & & $x$ & $x$ & $x$ & \\
\hline$x$ & & $x$ & & & & $x$ & & $x$ & $x$ & $x$ \\
\hline$x$ & $x$ & $x$ & & & $x$ & & & & & $x$ \\
\hline
\end{tabular}

\begin{tabular}{|c|c|c|c|c|c|c|c|c|c|}
\hline$x$ & $x$ & & & & $x$ & $x$ & $x$ & $x$ & $x$ \\
\hline$x$ & $x$ & $x$ & & $x$ & & $x$ & & & \\
\hline$x$ & & & & & $x$ & & & $x$ & \\
\hline$x$ & & & $x$ & & & $x$ & $x$ & & \\
\hline$x$ & $x$ & & & & & & & $x$ & $x$ \\
\hline & & $x$ & & $x$ & & $x$ & $x$ & & \\
\hline
\end{tabular}

(a) DOE/EES program has no internal data bank, but on-line retrieval capability is available through the National Technical Information Service, the Office of Science and Technology Information and Edison Electric Institute.

b) DOE/EES program has no internal information dissemination center, but copies of reports are disseminated by the National Technical Information

Service, the Office of Science and Technology Information and individual program managers.

(c) This category includes providing inputs to standards and codes, which is a prominant feature of many DOE/EES research projects. 
be more related to style than to content or scope. Interviews with program managers revealed that they are aware of the need to undertake technology transfer activities and are generally effective in transferring information to their professional peers.

The primary improvement recommended for the DOE/EES program technology transfer activities is to increase the visibility of the program. Despite the best efforts of the program managers to encourage technology transfer, the program is not well known among industrial decision makers. Not enough emphasis has been placed on obtaining publications and giving presentations directed at this audience. For example, no articles directly attributed to DOE/EES research were printed in Transmission and Distribution magazine, Electric Light and Power, or the EPRI Journal over the past two years. To increase program visibility, suggestions for improving technology transfer activities include more emphasis in the following areas:

- publications in trade literature such as Transmission and Distribution magazine, Power Engineering, etc.

- presentations at industrial trade conferences attended by utilities and equipment manufacturers, such as the Energy Technology Conference, the Pacific Gas and Electric Energy Exposition, etc.

- developing concise information on the nature and progress of DOE/EES research projects and on targeting this information to appropriate audiences

- selecting and actively transferring through cost-sharing agreements, personnel transfers, etc. a limited number of DOE/EES technologies

- obtaining more industry input in designing research programs. Analysis of the current interest in the various elements of the DOE/EES program indicates that systems technology and reliability research and development should be given the highest priority in future technology transfer efforts. The only component of these two program areas that should receive a low priority in transfer activities is the Hawai deep water cable program. This program is so specific in nature that its target audiences will likely seek out the necessary information. Electric field effects should be given a 
lower level of effort in technology transfer because of the already high visibility and level of interest in this program on the part of its audiences.

After analysis of the DOE/EES research program in terms of its projects, target audiences, current technology transfer activities, and suggested improvements, a plan for guiding the technology transfer activities of the program over the next two years was developed. This plan is segmented into two parts that describe those centralized technology transfer activities that apply to the entire DOE/EES program and those that are to be performed at the individual program level.

A suimary of the centralized technology transfer activities in the DOE/EES program that are planned for the next two years is shown in Table 2.4. Major elements of these planned activities include:

TABLE 2.4. Centralized Technology Transfer Activities for DOE/EES Program Over the Next Two Years

\begin{tabular}{l}
$\begin{array}{c}\text { Responsible } \\
\text { Individual(s) }\end{array}$ \\
\hline J. W. Hurwitch/ \\
L. L. Fassbender/ \\
R. M. Smith
\end{tabular}

Activities to be Conducted/Coordinated

1. Develop format for one-page project description sheets

2. Develop EES program mailing list

3. Coordinate selection of two or three appropriate projects for active transfer

4. Edit and distribute one-page project description sheets

5. Survey, document and report annual technology transfer activities

6. Suggest mechanisms to promote cost sharing, personnel transfer and other active technology transfer activities for selected projects
Target Dates

for Activity

Completion

$10 / 86$

$12 / 86$

$3 / 87,3 / 88$

$2 / 87$

$6 / 87,6 / 88$

$6 / 88$ 
- developing a format (patterned after EPRI project description sheets) that will be used to guide the development of DDE/EES one-page description sheets

- editing, assembling and distributing one-page project description sheets

- coordinating the selection of several projects for active technology transfer to industry through cost sharing, personnel transfer, technical assistance, etc. and the promotional activities directed towards achieving this active transfer

- collecting information from industry regarding research needs and priorities

- documenting technology transfer activities through development of an annual report.

Lists of the technology transfer activities planned for DOE/EES research program managers over the next two years are shown in Tables 2.5 and 2.6. A primary element of planned activities is continuing current efforts in the areas of technical publications, presentations at technical meetings, personnel transfers, etc. The only major differences from current activities are as follows:

TABLE 2.5. Project Level Technology Transfer Activities for Electric Field Effects, EMP and Hawaii Deep Water Cable

Responsible Individual $(s)$
W. Wisecup/L. Rosen--Electric
Fjeld Effects; R. Barnes--EMP;
R. Eaton--Hawai i Deep Water
Cable

\author{
Activities to be \\ Conducted/Coordinated \\ Continue present technology \\ transfer activities \\ Continue to provide data on \\ projects, distribution lists \\ and technology transfer \\ activities as requested \\ Provide input for develop- \\ ment of one-page project \\ description sheets
}

Target Dates for Activity Completion

$6 / 88$

$4 / 87$

$12 / 86$ 
TABLE 2.6. Project Level Technology Transfer Activities for All Other Program Elements

\begin{tabular}{|c|c|c|}
\hline Responsible Individual(s) & $\begin{array}{l}\text { Activities to be } \\
\text { Conducted/Coordinated }\end{array}$ & $\begin{array}{l}\text { Target Dates } \\
\text { for Activity } \\
\text { Completion }\end{array}$ \\
\hline $\begin{array}{l}\text { T. Rizy/T. Reddoch--Normal/ } \\
\text { Emergency Operating Concepts; }\end{array}$ & $\begin{array}{l}\text { Continue present technology } \\
\text { transfer activities }\end{array}$ & $6 / 88$ \\
\hline $\begin{array}{l}\text { M. Epstein--Failure Mechanisms; } \\
\text { J. Stovall--HVDC Research; }\end{array}$ & $\begin{array}{l}\text { Continue to provide data on } \\
\text { projects, distribution lists } \\
\text { and technology transfer } \\
\text { activities as requested }\end{array}$ & $4 / 87$ \\
\hline $\begin{array}{l}\text { E. Forsyth--Superconducting } \\
\text { Technology; }\end{array}$ & $\begin{array}{l}\text { Drovide input for develop- } \\
\text { ment of one-page project } \\
\text { description sheets }\end{array}$ & $12 / 86$ \\
\hline \multirow[t]{3}{*}{$\begin{array}{l}\text { J. Stoval1--Automation/ } \\
\text { Processing Concepts; } \\
\text { J. Hurwitch--Battery Energy } \\
\text { Storage/Load Leveling }\end{array}$} & $\begin{array}{l}\text { Coordinate publication of at } \\
\text { least two articles in } \\
\text { industry trade literature } \\
\text { and two presentations at } \\
\text { trade conference }\end{array}$ & $6 / 88$ \\
\hline & $\begin{array}{l}\text { Submit candidate projects } \\
\text { for active technology } \\
\text { transfer }\end{array}$ & $3 / 87$ \\
\hline & $\begin{array}{l}\text { Be available for possible } \\
\text { participation in active } \\
\text { technology transfer } \\
\text { activities }\end{array}$ & $6 / 88$ \\
\hline
\end{tabular}

- an increased emphasis on obtaining publications in industrial trade literature and presentations at trade conferences

- development of one-page description sheets according to a standardized format

- participation in an organized process of selecting and promoting projects for more active transfer through cost sharing, personnel transfer, etc.

- provision of data on an annual basis describing technology transfer activities. 
The activities listed in Tables 2.4, 2.5 and 2.6 will strengthen the existing active technology transfer program within DOE/EES and increase the program's visibility. This will enable DOE/EES to perform its mission of supporting research more successfully and improve the safety, reliability and economics of operating the nation's electric transmission and distribution system. 
. 


\subsection{ELECTRIC ENERGY SYSTEMS PROGRAM STRATEGY AND GOALS}

The current DOE/EES program contains a variety of projects designed to address distinct research and development needs within the electric utility industry. These needs and the strategies the DOE/EES program uses to address them are briefly described in this chapter. Summaries of each of the various EES research projects are presented. The general requirements for a successful technology transfer program for DOE/EES are described, and the chapter concludes with a presentation of the general strategies and goals of the DOE/EES technology transfer program.

\subsection{ELECTRIC FIELD EFFECTS STRATEGIES}

The human health risks of exposure to high-voltage electric fields has been a subject of concern for utilities, environmental groups, regulatory agencies, and anyone who lives or works close to existing or proposed transmission and distribution facilities. Recent court decisions have highlighted the need for research on electric field effects. In one case, a large utility in the Southwest was ordered to incur estimated costs of approximately $\$ 350 \mathrm{mil}$ lion to reduce the level of exposure to electric fields around a public school by either changing the route of a transmission line or rebuilding the school in another location.

Individuals need to be protected from excessive health risks that may be imposed by exposure to transmission and distribution facilities. The effects of such facilities on agricultural livestock and wild animals are also of concern. Society exercises its responsibility to protect citizens from undue risks through national environmental regulations, state and local zoning laws, court imposed restrictions on facility siting and design, and other methods.

However, these restrictions of ten impose costs on utilities and their customers. For example, the costs of building underground transmission lines to reduce exposure to high-voltage are generally significantly higher than the costs of overhead lines. As the size of the right of way that must be obtained for building a transmission or distribution facility grows, the associated land purchase cost for the facility increases. The regulatory and legal procedures 
in obtaining approval for a new transmission and distribution facility can indefinitely delay or completely stop the construction of such a facility.

The costs and delays associated with building new transmission and distribution facilities may inhibit the nations's electrical system from operating more efficiently. Sales of electricity from low-cost surplus areas to highercost deficit areas are often constrained by transmission and distribution capacity. For example, significantly more power could be economically transferred between the Pacific Northwest region and the Pacific Southwest region if the capacity of the transmission system between the two areas were larger.

A major problem in developing standards for exposure to high-voltage facilities that do not impose excessive costs on utilities and their ratepayers has been that the human health risks associated with such exposure are not well defined. In addition, utility-sponsored research on the subject will of ten be regarded as biased. Research by environmental and other groups advocating highly restrictive standards may be regarded in a similar fashion. Therefore, objective research on electric and magnetic field effects is needed to provide a basis for the development of standards that protect society from any excessive health risks while not imposing unnecessary costs on utilities and their ratepayers.

The DOE/EES electric field effects program is intended to develop an objective body of research on the impacts of exposure to electric and magnetic fields on biological processes. This work is intended to lead to the development of standards for exposure that can be applied by appropriate regulatory bodies, such as state environmental agencies, in regulatory and legal proceedings related to transmission and distribution facility siting, design and operation.

The EES electric field effects research has traditionally been divided into two subcategories:

- biological research--alternating current (a.c.)

- biological research--direct current (d.c.). 
The two types of research do not differ significantly in terms of their goals and objectives; therefore, they will be treated as one topical research area (electric field effects) for the remainder of this report.

The 14 research projects in electric field effects can be broadly separated into two major components that include:

- projects to identify the biological effects of electromagnetic fields and to understand the interaction of the biological mechanisms that produce these effects

- projects to determine how to apply the biological effects research to humans and to develop methodologies to analyze human risk associated with electromagnetic field exposure.

A listing of the 14 projects, their performing organizations and individuals, and a short summary of their major objectives and components are presented in Table A.1 of Appendix A.

\subsection{RELIABILITY RESEARCH AND DEVELOPMENT STRATEGIES}

A reliable electric network is required for a stable and healthy economy. In general, power interruptions result in high costs to both utilities and their customers. Breakdowns of system components that require repair and/or replacement also impose costs. Utilities usually do a good job of maintaining system reliability, but the increasing complexity of the electrical network makes maintaining system reliability more difficult. In addition, the possibility exists that the nation's electrical grid could be threatened militarily by devices capable of producing rapid electromagnetic pulses within electric transmission and distribution facilities.

The reliability research and development component of the DOE/EES program is structured to perform research in three subcategories:

- electromagnetic pulse (EMP) impact analysis

- normal/emergency operating concepts

- failure mechanisms.

Each of these areas is discussed in this section. 


\subsubsection{EMP Impact Analysis}

A high-altitude nuclear explosion could produce a transient electrical pulse that could result in widespread blackout of the nation's electrical system. Equipment manufacturers and utilities have generally designed their transmission and distribution systems to withstand surges induced by lightning and other natural causes within expected tolerance levels. However, research indicates that current tolerance levels are not adequate to protect against the abnormal surges induced by a high-altitude nuclear explosion.

National security requires research to reduce the vulnerability of elect-ical grids to power interruptions resulting from sabotage and military actions. In addition, the concepts and hardware developed as part of this research could be useful in improving the reliability of utility transmission and distribution systems under more normal conditions.

To develop equipment capable of withstanding abnormal electrical surges, quantitative estimates are needed of the likely magnitude and distributions of these surges within an electrical transmission and distribution system. Once these estimates are available, the resulting damages to existing electrical systems can be assessed. Components can be developed to withstand the predicted surge levels and the costs of hardening/supression options can be evaluated.

EES-supported research on EMP impact analys is is directed toward both assessing the likely magnitudes, distributions and impacts of EMP induced surges and toward developing new technologies more capable of withstanding suc? surges. The long-term goal of the research is to enable electric power systems impacted by EMP-induced surges to: 1) provide power to critical customers sucn as Civil Defense, military organizations, and critical industries; 2) minimize damage to the overall power system; and 3) minimize power outage time to the public.

Currently, 11 research projects are being supported by DOE/EES in EMP impact analysis. Surmaries of these projects are presented in Table A.2 of Appendix A. 


\subsubsection{Normal/Emergency Operating Concepts}

Advanced computer-aided automated control technologies could produce higher levels of electric power system reliability and lower levels of economic losses from interruptions through faster, more accurate detection and correction of system instability problems. However, further research is needed on methods of accomplishing total system control using the most advanced theory and control algorithms that still allow appropriate human intervention.

The addition of decentralized power generating units (e.g., small solar panels, wind machines, and cogeneration units) to the electrical grid has increased the reliability and control problems associated with operating electrical transmission and distribution systems. Such additions will represent a significant proportion of future additional generating capacity. However, generating units should not simply be connected to the grid without consideration of the impacts of these units on the total power system. Solid-state electrical appliances have also introduced complexities into obtaining efficient operation from transmission and distribution systems.

The normal/emergency operating concepts research supported by DOE/EES is intended to develop and enhance detection and control technologies for reducing the frequency and costs of power delivery interruptions. Specific research problems being addressed include methods of controlling the integration of decentralized power units and solid-state appliances into electrical grids.

There are 17 ongoing DOE/EES-supported research projects in the area of normal/emergency operating concepts. These projects are summarized in Table A.3 of Appendix A.

\subsubsection{Failure Mechanisms}

Continued research is needed on the failure mechanisms of materials used in electric transmission and distribution systems. The decline of research and development activities by domestic electric system equipment manufacturers has increased the need for a sustained national commitment to failure mechanisms 
research. Such research will provide designers of transmission and distribution systems with accurate data on the causes and frequencies of failure for the various dielectric materials used in cables, capacitors, transformers, motors, and generators.

The goal of the failure mechanisms research being supported by DOE/EES is to gain a fundamental understanding of the causes of failures in current electrical system components that witl contribute to the development of future com.* ponents with higher reliabilities and longer operating lives than currently available equipment. In reference to this goal, the four research projects summarized in Table A.4 of Appendix A are currently being conducted.

\subsection{SYSTEMS TECHNOLOGY STRATEGIES}

The needs associated with systems technology research can be described as:

- a need to facilitate the linking and interactions of complex electric transmission and distribution networks

- a need to reduce the energy losses and costs associated with electricity transmission and distribution

- a need to control the levels of peak electric power demands In association with these needs, DOE/EES is supporting research in six areas:

- HVDC research

- new materials research

- superconducting technology

- automation/processing concepts

- BEST facility/load leveling research

- Hawaii deep water cable research.

Each of these areas are described in the remainder of this section.

\subsubsection{HVDC Research}

HYDC transmission offers several potential advantages compared with the more widely used alternating current transmission systems; these advantages 
include improved systems control, enhanced operating performance, higher efficiency, and lower cost. The benefits of HVOC are particularly evident in applications involving transport of power from remote generating sites and in linking transmission systems across regional and national boundaries. Such linkages are increasing as different power suppliers attempt to integrate more closely their power supply operations.

Although HVOC transmission is already being used on a limited basis for point-to-point connections, technological barriers remain to the widespread penetration of HVDC transmission in all applications where its usage would be advantageous. For example, dynamic problems arising from d.c./a.c. system interaction and from multiterminal system connections must be solved before widespread expansion of HVDC transmission will take place. Additionally, some basic concepts need to be developed for applying HVDC systems technology in a network concept.

Current research supported by DOE/EES in the area of HVDC power transmission is intended to develop new technologies and control concepts for HVDC that will reduce the technological barriers to expanded HVOC usage. Analyses of the economics of HVDC are also important elements of this research. The eight research projects currently being conducted in HVDC research are sumarized in Table A.5 of Appendix A.

\subsubsection{New Materials Research}

New materials for electrical system components offer the potential for significant reductions in system losses, improved system reliability and reduced costs. The need for a national comitment to new materials research and development is increased by the decline in such activity on the part of domestic electrical equipment manufacturers. This decline has led to a reliance on foreign suppliers of such equipment; for example, there is no longer a domestic supplier of extra-high-voltage and ultra-high-voltage power circuit breakers.

Significant losses occur as electricity is transported from its point of production to the point of end-use consumption. Utilities and their ratepayers will benefit from reducing these losses because the need to build expensive new 
generating facilities to meet additional demands will be reduced. The cost savings from efficiency improvements in transmission and distribution systems are enhanced by the fact that the energy savings from such improvements are significantly higher during peak periods than during off-peak periods. Thus, the requirements for utilities to build and operate high-cost peak generating facilities are reduced by a greater proportion than the overall reduction in generating needs.

To reduce transmission and distribution system losses, reduce system lifecycle costs and improve system reliability requires research and development in several areas, including basic research on advanced materials for electrical equipment. DOE/EES-supported research in new materials is aimed at improving fundamental electrical, mechanical and optical properties of the materials used in system cables, transformers, generators and other types of electrical equipment. The 12 projects currently being performed as part of this research are summarized in Table $A .6$ of Appendix $A$.

\subsubsection{Superconducting Technology}

Research in the area of superconducting technology is closely related to research in the area of new materials. The attractive features of superconducting power equipment include low electrical losses, high current densities, and high reliability. The original objective of the superconducting cable research was to develop a transmission cable that would be capable of transporting large amounts of electricity through heavily populated areas with limited rights of way. However, because of market forces, the emphasis of the program has now shifted towards using the knowledge gained in the superconducting cable research to develop an ambient cable and a superconducting generator. The three projects currently being conducted in the area of superconducting technology are summarized in Table A.7 of Appendix A.

\subsubsection{Automation/Processing Concepts}

Advanced automation and data processing concepts offer the potential for significantly improving the resource utilization and operating efficiencies of interconnected power systems. Large-scale interconnected systems consist of hundreds of machines and thousands of transmission lines and loads. If the 
operation of these individual components can be better coordinated and controiled through automation, reserve margins for generation, transmission and distribution systems may be reduced. Such reductions could significantly reduce total power generation and delivery costs by lessening the need to maintain as many costly peak generating units and transmission/distribution facilities.

Automation can reduce system costs by improving the efficiency and productivity of normal power system operations. It could improve the ability of utilities to implement direct load control programs among their customers for purposes of reducing peak demands.

The goal of automatiol/processing concepts is to develop new technologies and procedures for power suppliers to better monitor and control the performance of their total power systems. These technologies and concepts are likely to become increasingly important as power systems become more dispersed and complex. In support of the goal of the automation/processing concepts research effort, DDE/EES is supporting nine different research projects. These projects are sumnarized in Table A.8 of Appendix A.

\subsubsection{Battery Storage/Load Leveling}

Battery energy storage technology systems have a significant potential for reducing the peak capacity requirements of electrical power systems by storing energy generated during off-peak hours for later use during peak hours. These systems would serve to reduce off-peak generation needs, result in more efficient resource utilization and reduced system costs.

A number of technical and economic issues need to be resolved before the potential benefits of battery systems are realized. These issues include the evaluation of experimental batteries in realistic utility applications, the effects of battery storage systems on transmission and distribution system reliability, and the comparative costs of battery storage systems and the peak generating units that they would displace.

Research supported by DOE/EES is intended to provide a means for the development and testing of battery energy storage systems in realistic utility 
applications, such as the BEST facility. In relation to this objective, the DOE/EES program includes the three projects 1 isted in Table A.9 of Appendix A. 3.3.6 Hawaii Deep Water Cable

Hawai has traditionally depended upon fossil-fuel-fired generating units to produce the majority of its electric power. However, advancements in the technology of deep water cable installations can make feasible the linking of Hawaji's primary electric demand region on the island of Oahu with geothermal generating facilities on the island of Hawail. Such a linking would reduce Hawaij's dependence on imported oil and potentially provide long-term benefits to electricity consumers.

Although underwater electric cables are already being used to transport electricity in various locations, the Hawaij deep water cable installation would represent a significant step in terms of the depth of cable placement and the harsh bottom environment in which the cable would have to operate. Research is needed to determine the technical and economic feasibility of such an installation. This research will benefit both domestic cable manufacturers and the state of Hawaii.

The goal of the DOE/EES research in the Hawai i deep water cable project is to develop critical data needed to determine the feasibility of cable installation and operation. The two projects currently being conducted in reference ts this goal are listed in Table A.10 of Appendix A.

\subsection{EES PROGRAM TECHNOLOGY TRANSFER NEEDS}

The technologies and information developed as part of the EES program are only useful if they are eventually used to improve the equipment, operation or regulatory policies associated with electrical transmission and distribution systems. Therefore, the transferring of EES program research to audiences capable of using the research is required.

Although the concept of technology transfer has recently received increased emphasis at all levels of government, it should be noted that extensive technology transfer efforts have been conducted as part of the EES prograın for some time. However, the need was seen to organize and document these 
efforts in a more rigorous fashion and to develop information that could facilitate technology transfer by the various components of the EES program.

Sections 3.1 to 3.3 of this report show the diversity of the research projects supported by DOE/EES. The appropriate audiences for technology transfer efforts associated with the projects are also diverse; therefore, technology transfer efforts will need to be carefully tailored to these audiences.

Because the DOE/EES program is government-supported, efforts have been placed on performing intermediate and long-term research that is not likely to be performed by industry. Some of this research is basic in nature and may not be appropriate for direct transfer to industry audiences. Thus, the various types of research projects being performed as part of the DOE/EES program need to be characterized in terms of their appropriateness for transfer to various types of audiences.

In addition to accounting for project diversity in technology transfer efforts, it is important to account for the limitations imposed by resource constraints in developing an implementable technology transfer pian. Some methods of technology transfer may simply be too costly to be feasible in the current federal expenditure environment. Therefore, technology transfer methods are needed that will be effective in transferring EES-supported research to appropriate audiences, but will not be prohibitively expensive.

\subsection{GENERAL STRATEGY OF OOE/EES TECHNOLDGY TRANSFER PROGRAM}

Because of the diversity of projects supported by DOE/EES, the general focus of the DOE/EES program will be on conducting technology transfer activities at the project level. The primary purpose of the program is to organize and facilitate technology transfer efforts by those that are most familiar with the research in the various areas. Emphasis will be placed on developing a plan that is both feasible and effective in transferring DDE/EES research to appropriate audiences. To accomplish this goal, specific technology transfer activities will be identified and personnel assignments for performing these activities will be specified. 
The strategy of emphasizing technology transfer at the research project level is supported by other writers with substantial experience in transferring technology and information developed as part of government supported research (Traeger 1984). Therefore, information gathered from technical experts within the various research areas of the DOE/EES program serves as a primary data source for the development of the EES technology transfer plan.

Facilitation of technology transfer efforts is performed in this plan by characterizing the stage of research/development of each research project supported by DOE/EES. This information is then used in defining appropriate target audiences for technology transfer efforts related to the various projects. The types of technologies developed in each of the projects are also characterized, in order to suggest appropriate methods of technology transfer.

A description of current technology transfer efforts in the various DOE/EES program components is used as a basic framework for suggesting modifications of current efforts and in defining future efforts. Assignments of personnel to conduct these efforts are then developed. 


\subsection{ELECTRIC ENERGY SYSTEMS PROJECT CHARACTERIZATIONS}

The successful and efficient transfer of technologies requires that the research projects be characterized in terms of the types of products they are intended to produce. It is necessary that the projects be characterized so that their objectives, progress and results can be appropriately communicated to external audiences.

\subsection{CHARACTERIZATION VARIABLE DEFINITIONS}

The nature of a technology is a critical factor in determining appropriate transfer activities. For example, a technology that is highly technical in nature and in the early stages of research will usually not be appropriate for transfer to nontechnical decision-makers. Such audiences will likely not understand nor be able to make use of such research. Projects involving the development of information will usually not be appropriate for such transfer methods as demonstration programs because there is no tangible product to demonstrate.

In order to define appropriate audiences and transfer methods for the various EES projects, a matrix for characterizing these projects was implemented. This matrix (shown in Table 4.1) is designed to describe the various EES projects along two dimensions: 1) stage of research and development, and

2) type of technology being developed. The characterization variables included in this matrix are defined at the bottom of Table 4.1. Although the matrix shown in Table 4.1 is somewhat arbitrary in its definitions, it is believed to provide a useful framework for describing the nature of the EES/DDE program.

\subsection{DOE/EES PROJECT CHARACTERIZATIONS}

The project characterizations presented in this section were developed from short field interviews and mail surveys with various technical research managers from within the EES program. In some cases, individual projects fit into more than one of the variable classifications shown in Table 4.1. The distinction between basic and applied research was particularly difficult for 
TABLE 4.1. Matrix Used to Characterize Research Projects

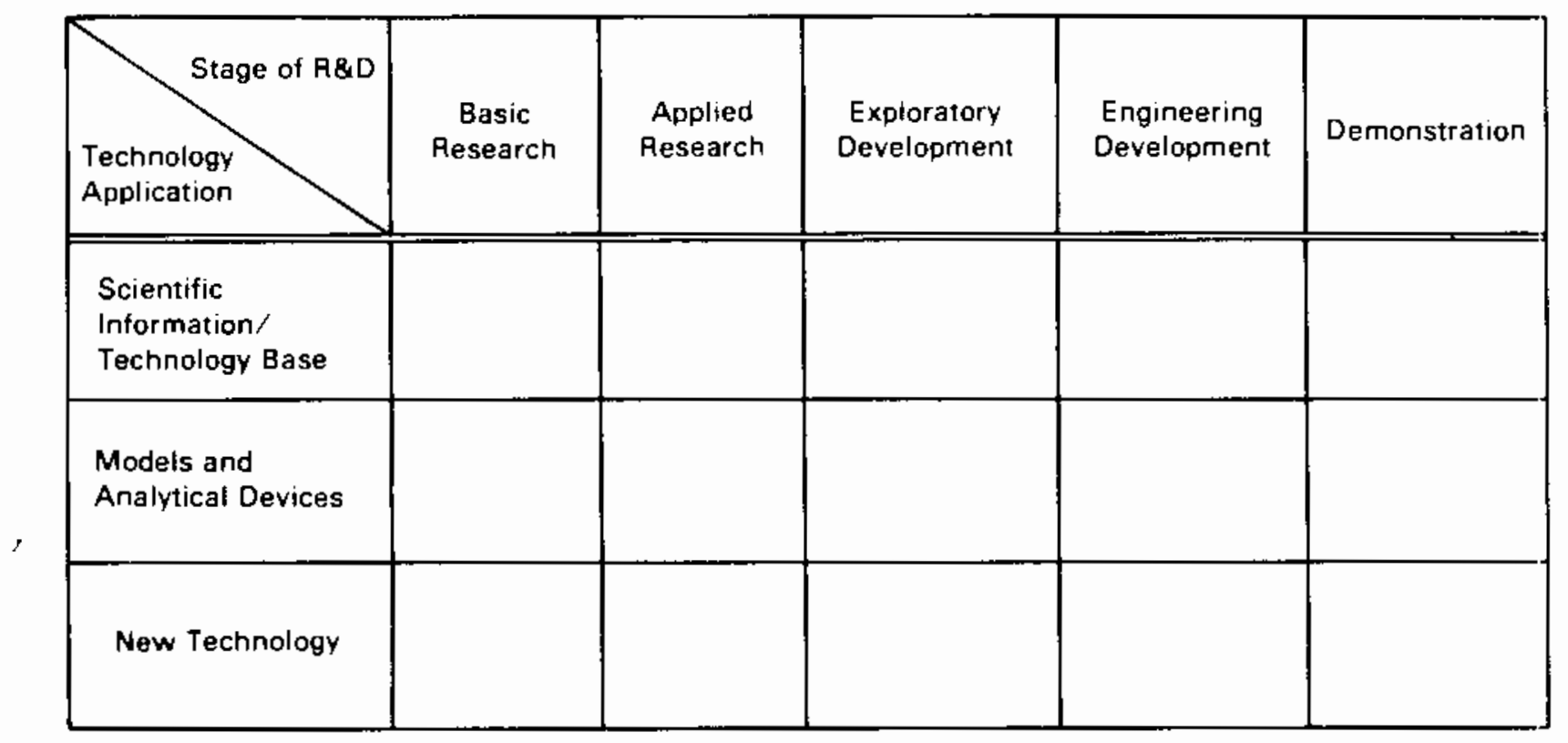

Stages of R\&D:

1. Basic Research - Basic investigation including all effort toward increased knowledge of natural phenomena, solution of problems in various sciences, and identification of new technological concepts.

2. Applied Research - Extension of basic research whereby the specific application of increased knowledge is envisioned, may include some preliminary design toward practical solutions.

3. Exploratory Development - Solution of specific problems short of major development projects, exploring such problem areas with a view toward developing soiutions; early concept formulation efforts.

4. Engineering Development - More mature development of hardware and systems being engineered for service use, but not yet ready for commercial operation.

5. Demonstration - Use of hardware and systems in a prototype commercial operation.

Research Applications:

1. Scientific Information/Technology Base - The ultimate product of the research is information and data that can be used in making policy decisions, evaluating products, or testing theories.

2. Models and Analytical Devices - The result of the research is a device/tool that can be used in conducting further research or a model that can be used in research and/or commercial application.

3. New Technology - Equipment or components that can be used in commercial applications.

some projects. Such projects were placed into both categories. Participants in the field interviews were selected based on their extensive knowledge of tre various technical projects.

The results of characterizing the various EES projects are summarized in Tables 4.2 to 4.5 . Table 4.2 presents the number of projects in each program 
TABLE 4.2. Number of EES Projects Characterized into Each Stage of Research

\begin{tabular}{|c|c|c|c|c|c|}
\hline EES Program Area & $\begin{array}{r}\text { Basic } \\
\text { Research } \\
\end{array}$ & $\begin{array}{l}\text { Applied } \\
\text { Research } \\
\end{array}$ & $\begin{array}{l}\text { Exploratory } \\
\text { Development }\end{array}$ & $\begin{array}{l}\text { Engineering } \\
\text { Development }\end{array}$ & Demonstration \\
\hline $\begin{array}{l}\text { Electric Field } \\
\text { Effects }\end{array}$ & 6 & 7 & 0 & 0 & 0 \\
\hline $\begin{array}{l}\text { EMP Impact } \\
\text { Analysis }\end{array}$ & 3 & 6 & 1 & 0 & 0 \\
\hline $\begin{array}{l}\text { Norma } 1 / \text { Emergency } \\
\text { Operating } \\
\text { Concepts }\end{array}$ & 5 & 8 & 1 & 3 & 0 \\
\hline $\begin{array}{l}\text { Failure } \\
\text { Mechanisms }\end{array}$ & 0 & 3 & 0 & 1 & 0 \\
\hline HVDC Research & 1 & 4 & 1 & 1 & 0 \\
\hline $\begin{array}{l}\text { New Materials } \\
\text { Research }\end{array}$ & 11 & 2 & 0 & 0 & 0 \\
\hline $\begin{array}{l}\text { Superconducting } \\
\text { Technology }\end{array}$ & 0 & 0 & 2 & 1 & 0 \\
\hline $\begin{array}{l}\text { Automation/Pro- } \\
\text { celling Concepts }\end{array}$ & 2 & 4 & 3 & 0 & 0 \\
\hline $\begin{array}{l}\text { BEST/Load } \\
\text { Leveling }\end{array}$ & 0 & 2 & 0 & 1 & 0 \\
\hline $\begin{array}{l}\text { Hawai i Deep } \\
\text { Water Cable }\end{array}$ & 0 & 0 & 2 & 0 & 0 \\
\hline Totals & $\overline{28}$ & $\overline{36}$ & $\overline{10}$ & $\overline{7}$ & $\overline{0}$ \\
\hline
\end{tabular}

area (electric field effects, EMP, etc.) that fit into each of the five stages of research and development. Table 4.3 presents estimates of the percentages of current year budget allocations within a program area comprised by projects that were placed into each of the five stages of research and development categories. In Table 4.4, data on the number of projects that fit into each of the three types of application categories (scientific information, models and analytical devices, new technology) are presented. The percentages of current year budget allocations for each program area comprised by the three application categories are shown in Table 4.5 . 
TABLE 4.3. EES Program Stage of Research Budget Allocation Summary

\begin{tabular}{|c|c|c|c|c|c|}
\hline \multirow[b]{2}{*}{ EES Program Area } & \multicolumn{5}{|c|}{ Percent of Program Aree Budget } \\
\hline & $\begin{array}{l}\text { Bostc } \\
\text { Reseerch }\end{array}$ & $\begin{array}{l}\text { ApplTed } \\
\text { Research }\end{array}$ & $\begin{array}{l}\text { ExpTorbtory } \\
\text { Development }\end{array}$ & $\begin{array}{l}\text { Englneerling } \\
\text { Development }\end{array}$ & Demonstration \\
\hline Electrlc Fleid Effects & 39 & 61 & & & \\
\hline EMP Impact Analysis & 38 & 52 & 10 & & \\
\hline $\begin{array}{l}\text { Normal / Emergency } \\
\text { Operating Concepts }\end{array}$ & 39 & 58 & & 3 & \\
\hline Fall ure Mechanls ms & & 100 & & & \\
\hline HYOC Research & & 11 & 15 & 74 & \\
\hline New Moterials Research & 27 & 18 & 55 & & \\
\hline Superconducting Technolo & & & & & \\
\hline $\begin{array}{l}\text { Automation/Processing } \\
\text { Concepts }\end{array}$ & 28 & 39 & 33 & & \\
\hline BEST/Load Level Ing & & 100 & & & \\
\hline Hawall Deep Water Cable & & & 100 & & \\
\hline Totals & 32 & 51 & 15 & 2 & \\
\hline
\end{tabular}

\section{TABLE 4.4. Number of EES Projects Characterized Into Each Technology Application}

\section{EES Program Area}

Electric Field Effects

EMP Impact Analysis

Normal/Emergency Operating Concepts

Failure Mechanisms

HVDC Research

New Materials Research

Superconducting Technology

Automation/Processing Concepts

BEST/Load Leveling

Hawaii Deep Water Cable

Totals

\begin{tabular}{cccc}
$\begin{array}{c}\text { Scientific } \\
\text { Information }\end{array}$ & $\begin{array}{c}\text { Models and } \\
\text { Devices }\end{array}$ & & $\begin{array}{c}\text { New } \\
\text { Technology }\end{array}$ \\
\cline { 2 - 2 } 7 & 6 & 0 \\
7 & 2 & 1 \\
4 & 9 & 4 \\
2 & 1 & 1 \\
3 & 2 & 2 \\
9 & 0 & 5 \\
0 & 1 & 2 \\
1 & 4 & 4 \\
1 & 0 & 2 \\
$\frac{0}{34}$ & 27 & $\frac{2}{21}$
\end{tabular}


TABLE 4.5. EES Program Technology Application Budget Allocation Sumary

\begin{tabular}{|c|c|c|}
\hline $\begin{array}{l}\text { Percent } \\
\text { Scientific }\end{array}$ & $\frac{\text { Program Are }}{\text { Madels and }}$ & \\
\hline Information & Devices & Technology \\
\hline 74 & 26 & 0 \\
\hline 54 & 29 & 17 \\
\hline 13 & 71 & 16 \\
\hline 70 & 30 & 0 \\
\hline 11 & 0 & 89 \\
\hline 73 & 0 & 27 \\
\hline 0 & 0 & 0 \\
\hline 15 & 45 & 40 \\
\hline 5 & 5 & 90 \\
\hline$\underline{0}$ & 100 & 0 \\
\hline 47 & 30 & 23 \\
\hline
\end{tabular}

The emphasis of EES-sponsored research varies significantly from one area of research to another. For example, the emphasis of electric field effects is primarily on developing scientific information, whereas the emphasis of emergency operating concepts is on developing models and analytical devices. The results of the characterization process for each subcategory are briefly described below.

\subsubsection{Electric Field Effects}

The primary thrust in the area of electric field effects appears to be applied research. (a) The numbers of projects characterized as applied and basic research are approximately equal, but a higher level of budget allocation is associated with applied research projects. The present emphasis is on confirming the results of recent research and replicating any research that appears to indicate undue risk from electric field exposure.

(a) Information obtained from field interviews and completed surveys from Larry Anderson, PNL; William Wisecup, W/L Associates Ltd.; and Lee Rosen, $W / L$ Associates. 
A11 of the projects within the subcategory of electric field effects involve either the development of scientific information or the development of models and analytical devices. The numbers of projects in the two types of applications are approximately equal, but the budget allocation for scientific information development is significantly higher. More detailed information on the characterizations of each of the research projects in electric field effects is presented in Table B.1 of Appendix B.

\subsubsection{EMP Impact Analysis}

The majority of the projects in EMP are classified as applied research, a:d receive the majority of the program budget. (a) The emphasis within EMP in terms of number of projects and size of budget is on scientific information and data development. Only one project (zinc oxide varistor development) involves new technology development. More detailed information drawn directly from field interviews on the characterizations of individual EMP projects is presented in Table B.2 of Appendix B.

\subsubsection{Normal/Emergency Operating Concepts}

Normal/emergency operating concepts research is characterized primarily as applied, (b) in terms of number of projects and relative size of budget allocation. However, research in this area also includes several projects in the engineering development stage. The development of tools and models to enhance power system reliability receives primary emphasis, but the research also includes the development of several new hardware technologies. Additional information on the characterization of the projects in normal/emergency operat ing concepts is presented in Table B.3 of Appendix B.

\subsubsection{Failure Mechanisms}

Three of the projects in the subcategory of failure mechanisms are classified as applied research, whereas one project has progressed to the stage of

(a) Information obtained from field interviews and completed survey forms from Paul R. Barnes, Oak Ridge National Laboratory.

(b) Information obtained from field interviews and completed survey forms from Tom Rizy, Oak Ridge National Laboratory; Thomas Reddoch, Electrotek Concepts, Inc. 
engineering development. (a) Emphasis in the research is on developing scientific information pertaining to the nature and causes of failures within electric energy systems and analytical devices/models for predicting when and under what conditions failures will occur. Specific information on the characterization of each of the individual failure mechanisms projects is presented in Table $B .4$ of Appendix B.

\subsubsection{HVDC Research}

Four of the seven research projects in HVDC are classified as applied research. (b) The other three projects include a basic research project, a project involving exploratory development, and a project that has reached the stage of engineering development. The majority of the current program budget in HVDC is allocated to a high-phase-order transmission study that is characterized as engineering development. Three of the projects in HVDC involve scientific information development, two projects involve the development of analytical devices or models, and two projects involve new technology development. Most of the current program budget is allocated to developing high-phase-order transmission technology. Further information on the characterization of the individual HVDC projects is presented in Table B. 5 of Appendix B.

\subsubsection{New Materials Research}

All but three of the 14 projects in new materials research were characterized as basic research. (c) Two of the projects were categorized as applied research and one as exploratory development. However, much of the current budget for new materials research is allocated to a project involving exploratory development of an advanced-concept superconducting generator. Ten projects within new materials primarily emphasize scientific information

\footnotetext{
(a) Information obtained from a completed survey form from Michael Epstein, Battelle-Columbus Laboratories.

(b) Information obtained from field interviews and completed survey forms from John Stovall, Oak Ridge National Laboratory.

(c) Information obtained from field interviews and completed survey forms from S. J. Dale, Oak Ridge National Laboratory.
} 
development; five emphasize new technology development. Additional informatior on the individual projects within the new materials research program is presented in Table B.6.

\subsubsection{Superconducting Technology}

All of the projects in the subcategory of superconducting technology can be regarded as exploratory development and engineering development. (a) They involve development and testing of technologies related to improving the conducting properties of electric cables and generators; therefore, their results could potentially be directly applied in utility operations. Two of these projects involve new technolog; hardware development, and one involves the development of models and analytical devices. The project characterization matrix for superconducting technology is shown in Table B.7.

\subsubsection{Automation/Processing Concepts}

This research area comprises four projects in the applied research stage, three projects in the exploratory development stage and two projects in the basic research stage. (b) About one-half of the projects involve the development of models and analytical devices, and one-half were characterized as new technology hardware development projects. The current budget for automation/ processing concepts research is divided almost evenly between basic research, applied research and exploratory development. More detailed information on the characterization of the various projects in automation/processing concepts is presented in Table B.8.

\subsubsection{Battery Storage/Load Leveling Research}

The battery storage/load leveling research is primarily applied research, even though a project involving development of the zinc-chloride battery has reached the stage of engineering development. (c) Both the development of the

(a) Information obtained from a telephone interview and completed survey forms from Eric Forsyth, Superconducting Technology.

(b) Information obtained from field interviews and completed survey forms from Steve Purucker, Oak Ridge National Laboratory.

(c) Information obtained from a completed survey form from Al Pivec, Public Service Electric and Gas Company. 
BEST facility and the zinc-chloride battery project were characterized as new technology hardware projects. The other project within the battery storage/ load leveling research area, involving an assessment of electrochemical energy storage systems, is a scientific information development project. The characterization matrix for projects within battery storage/load leveling is presented in Table B.9.

\subsubsection{Hawaij Deep Water Cable}

One of the Hawaii deep water cable projects is characterized as applied research and the other as exploratory development. (a) A significant part of the program focuses on gathering scientific information on ocean floor conditions and developing simulation models of the cable-laying process to determine if a cable can be layed accurately under the severe conditions faced in the Hawailan islands. However, part of the program is also directed toward the development and testing of a new cable and is categorized as new technology hardware development. The characterization matrix for the Hawaii deep water cable project is presented in Table B.10. (a) Information obtained from field interviews and completed survey forms from
Charles Traugh, VSE, Inc. 


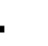

.
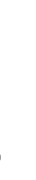


\subsection{TARGET AUDIENCES AND TRANSFER MECHANISMS FOR EES PROGRAMS}

In this section, target audiences for the EES program and possible transfer mechanisms for reaching these audiences are described.

\subsection{TARGET AUDIENCES}

Identifying and characterizing the target audiences for the diverse EES program technologies is an important step in limiting the wide scope of possible audiences for technology transfer efforts. This enables transfer efforts to be efficiently directed toward the individuals and organizations that are most concerned with particular elements of the EES program, and wasted efforts in terms of time and money can be reduced.

\subsubsection{Target Audience Identification}

EES program managers were asked to identify the individuals or organizations that are or should be the focus of their technology transfer efforts. The results of these findings can be seen in Table 5.1. Target audiences identified by these managers were grouped into the following categories: EPRI, electric utilities, scientific organizations, equipment manufacturers, and governmental agencies.

The type(s) and number of target audiences identified by the program managers varied depending on how specific the technology is to a certain area of interest and its stage in the research and development process. EPRI, because of its broad level of interest in electrical systems at all stages of development, represents a large portion of EES technology transfer efforts and was identified as a target audience for all research developed as part of the EES program (Table 5.1).

Electric utilities are another target audience group representing a large portion of current EES technology transfer efforts. Utility engineers and managers were identified as target audiences for all EES programs except for new materials research and the Hawai deep water cable. Research dealing with new materials for transmission and distribution equipment is perceived to be too far removed from the concerns of utility management and technical personnel 


\section{TABLE 5.1. EES Program Target Audiences}

EES Program Component

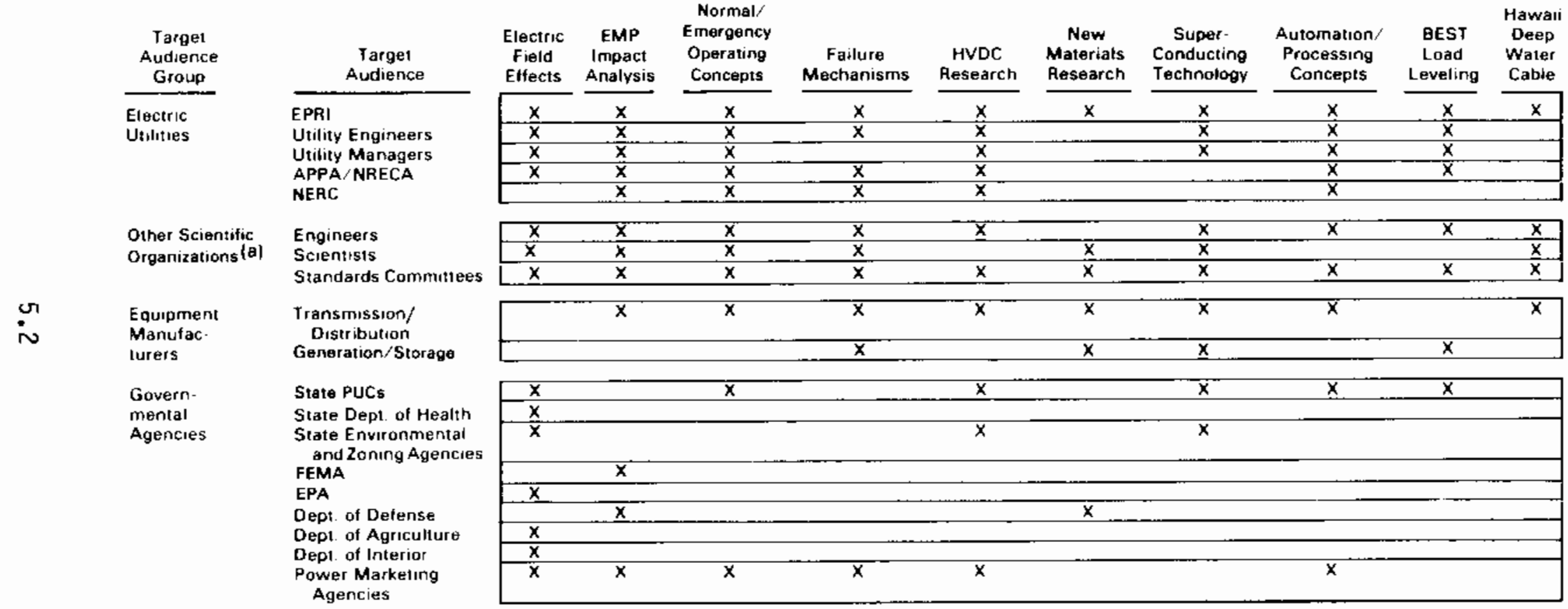

(a) Includes private research organizations, universities and other publicly funded research organizations. 
and, therefore, should be transferred to manufacturers of the equipment before being transferred to the utjlities. The Hawaii deep-water cable research is judged to be too specific in nature to be of interest to most utility managers.

Three national associations within the utility industry were identified as being target audiences for a number of EES programs that deal primarily with research that is far enough along and broad enough in scope to be of interest to their membership. As can be seen in Table 5.1, the Anerican Public Power Association (APPA), the National Rural Electric Cooperative Association (NRECA), and the North Anerican Electric Reliability Council (NERC), were identified as target audiences for research being conducted in electric field effects (APPA/NRECA only), EMP impact analysis, normal/emergency operating concepts, failure mechanisms, HVDC research, automation processing concepts, and BEST/load-leveling research.

Scientific groups identified as target audiences by EES program managers were engineers, scientists, and standards committees, as shown in Table 5.1. Engineers and scientists were identified as audiences for programs relevant to their respective scientific fields. Technical standards committees cparticularly those of the Institute of Electrical and Electronic Engineers (IEEE)] were identified as target audiences for all components of EES research. EES projects that are in the earliest (basic and applied) stages of research are the most likely candidates for technology transfer to scientific organizations.

Equipment manufacturers are target audiences for technology transfer, primarily when a technology is in the later stages of the research and development process. As shown in Table 5.1, transmission and distribution equipment manufacturers were identified as target audiences for all but one EES program. Electric field effects research, because of its orientation towards basic and applied studies that are not intended to develop new technology, does not target manufacturers. Power generation/storage equipment manufacturers are targeted as audiences by several components of EES research, including superconducting technology, new materials and BEST load leveling research.

A number of governmental agencies were identified as target audiences for EES research, including public utility comissions, state departments of health, state environmental and zoning agencies, the Environmental Protection 
Agency (EPA), the Department of Defense, the Department of Agriculture, the Department of the Interior, and the Federal Emergency Management Agency (FEMA).

Of the governmental agencies identified by EES program managers, public utility commissions and power marketing agencies were the most of ten identified target audiences for EES technology transfer. Electric field effects research targets substantially more governmental agencies than do other EES programs, as seen in Table 5.1. This is mainly due to the controversy over the effects of electric fields and the widespread implications of the research results.

\subsubsection{Target Audience Characteristics}

EES program target audience groups are briefly characterized and discussed in this section; they are EPRI, electric utilities, scientific organizations, equipment manufacturers, and governmental agencies.

\section{1 .2 .1 EPRI}

EPRI can be described as the research arm of the electric utility industry and is funded by electric utilities nationwide. Research and development efforts at EPRI tend to be intermediate in nature, somewhere between the shortterm efforts of individual utilities and the long-term efforts of DOE and other government research. However, the utilities that fund EPRI have recently beer applying pressure on it to fund research that is more short-term in nature thar it has traditionally supported. This will widen the gap between the long-term mission of the EES program and the shorter-term objectives of EPRI. Although this increases the need for a viable EES program to conduct long-term research, it also increases the difficulty of performing technology transfer from EES tc EPRI.

EPRI was founded in 1972 by the nation's electric utilities to develop are manage a technology program for improving electric power production, distribution, and utilization. Primary areas of research at EPRI are coal combustion systems, electrical systems, energy and environmental analysis, energy utilization and management, advanced power systems, and nuclear power (EPRI 1986). 
EPRI is often thought to be simitar in its mission and objectives to the EES program and, as a result of this, a considerable amount of coordination between EPRI and EES research exists. However, it is of ten difficult for EPRI to be considered objective in conducting research that could be viewed as detrimental to the utility industry (such as electric field effects). In addition, EPRI generally does not support research that has implications for national security (such as EMP).

\subsubsection{Electric Utilities}

Electric utilities are a main target audience of many EES programs. This audience is one of the largest industrial sectors in the country, and is extremely diverse in the size and scope of the operations of its individual members. Some utilities, such as Pacific Gas and Electric and Consolidated Edison, are large enough to support their own internal research staffs. In such cases, research information can be directly targeted to the utility. Other municipal and county utilities are so small that they have only five to 10 employees in total. For these utilities it is normally necessary to work through industry associations.

APPA and NRECA were identified as two utility associations constituting target audiences for EES program research. These two national associations are made up various utilities including public utilities, rural electric cooperatives, and state and county electric systems. APPA's main activities include research, compiling statistics, sponsoring competitions, and bestowing awards. NRECA's main activities include training and consulting services, youth programs, conservation and energy-efficiency campaigns, insurance and safety programs, and salary and wage surveys (Encyclopedia of Associations 1986a).

One other utility-oriented association, NERC, was identified as a target audience for EES research. NERC is made up of regional electric utility organizations concerned primarily with the reliability and adequacy of the U.S. bulk power supply (Encyclopedia of Associations 1986b). This association periodically reviews inter-regional reliability arrangements and acts as an information exchange center for planning and operating matters relating to reliability and adequacy of bulk power supply. 
Utility industry decision-makers are often characterized as being extremely conservative in terms of investing in new technology and research. The traditional perception of utilities is that they are regulated monopolies staffed by engineers who are primarily concerned with building and operating power-generating units. However, recent events have tended to modify this traditional outlook. The utility industry is becoming more competitive as "wheeling" and nontraditional power-generating resources (such as cogeneration) become more popular (Wa11 Street Journal 1986). In addition, a reluctance to build new generating units is becoming apparent as utilities have been financially damaged by the impacts of ongoing or recently completed construction projects. This suggests that a higher priority may be placed on transmission and distribution system capacity and efficiency than has traditionally been the case.

\subsubsection{Scientific Organizations}

EES programs that are at the earliest (basic and applied) stages of research are the most likely candidates for technology transfer to scientific organizations. Members of these organizations in universities and elsewhere are often conducting studies similar to specific EES programs; consequently, there is substantial interaction between these individuals and EES research personnel through technical standards committees and other forums.

Professional researchers are perhaps the easiest audiences to reach with EES program results because they are generally of the same peer group as the personnel that performed the research. In addition, technology transfer activities for research scientists, such as participation in technical conferences, are considered a part of EES program personnels' professional enhancement and thus, are readily performed by these personnel.

\subsubsection{Equipment Manufacturers}

Manufacturers of equipment used in electric energy systems are obvious target audiences for EES program technologies, usually when the technology is in the later stages of development. Equipment manufacturers are motivated by 
the potential for profit inherent in new technologies and benefit from large research and development efforts that they are financially unable to support on their own.

EES program information can be used by manufacturers to keep them up-todate on the state of their technical environment, to supplement or guide their own research and development efforts, or to provide the opportunity for new product development if the technology is in the final stages of design. Transmission and distribution equipment manufacturers were the main category of manufacturers targeted by EES project managers. Generation and storage equipment manufacturers were also mentioned.

Recently, the level of industrial activity by domestic transmission and distribution equipment manufacturers has declined significantly. Equipment supplied by foreign manufacturers constitutes an increasing proportion of total sales. Declining profitability and sales have caused equipment manufacturers to become more conservative in funding research and development. If a significant commitment to funding such research is to be made, it will probably not come from domestic manufacturers.

\subsubsection{Governmental Agencies}

Governmental agencies are important target audiences for much of the research being conducted by EES programs. Governmental agencies identified by EES project managers include: public utility commissions, state departments of health, state environmental and zoning agencies, state agencies for states with offshore islands, the Environmental Protection Agency, the Department of Defense, the Department of Agriculture, the Department of the Interior, and the Federal Emergency Management Agency. The electric field effects program transfers much of its research to these agencies, while other EES programs utilize these audiences to lesser degrees.

Of the governmental agencies identified by EES project managers, public utility commissions were the most frequentiy identified audience for technology transfer. Public utility comissions are responsible for regulating public service companies (including utilities) in terms of adequacy of service, responsibility and fairness of rates, issuance of securities, consolidations 
and mergers, and safety of operations. There are normally several divisions within state utility commissions. Divisions most concerned with EES technologies include engineering, utilities operation and management, analysis, and research and planning. Convincing public utility commissions of the benefits of a new technology is often a necessary step to convince utilities to adopt the technology.

Power marketing agencies of the federal government such as the Bonneville Power Administration and the Tennessee Valley Authority were also identified as target audiences for EES research. These federal agencies are responsible for distributing power to large numbers of utilities under their jurisdiction and are involved in a varjety of research activities.

\subsection{POTENTIAL EES PROGRAM TRANSFER MECHANISMS}

This section will identify and assess potential EES program technology transfer mechanisms and determine the general circumstances in which a transfer mechanism is most appropriate. Both active and passive technology transfer mechanisms will be identified along with the comparative advantages of each.

Three main factors should be considered when deciding on a particular technology transfer mechanism:

- target audience characteristics--audience size, technical knowledge level, economic conditions, size of research and development budget, and the audience's current level of interest in the particular technology

- stage of research and development--basic research, applied research, exploratory development, engineering development, or demonstration

- individual project characteristics--type of technology being developed (scientific information, analytical devices and models, or new technology), the potential impact of the technology on the target audience's operations, national importance of technology implementation, and the amount of resources available for technology transfer. 
Once these factors have been identified, passive, semi-active, or active methods of technology transfer can be used. Passive methods of technology transfer concentrate on information dissemination and may include publications, media announcements, etc. Active methods are oriented toward providing personal interaction and incentives for technology transfer and include more aggressive efforts such as personnel transfers to/from industry, joint government/industry tests, etc. Semi-active methods of technology transfer fall between passive and active methods and include technical meetings, exchanges, formal visits, etc. There are no distinct rules for defining or selecting a passive versus an active method of technology transfer; each method has advantages and disadventages depending upon the particular situation.

Passive transfer mechanisms normally require less effort on the part of project personnel and target audiences than active methods; this is an important factor when time and budgets are major constraints. Passive transfer methods tend to be used most often when the target audiences are large and diverse and the audience interaction is limited.

Passive methods tend to be "user-driven", meaning that the audience must make an effort to seek information on a particular technology. Due to budget constraints and other factors, passive methods are probably the most frequently used technology transfer methods for government research. Because there is less direct interaction between researchers and target audiences, passive technology transfer mechanisms are slower in communicating information. This may result in lost opportunities and potentially misinformed audiences. In the long run, however, missed opportunities for more effective transfer using other methods are difficult to measure.

Active methods of technology transfer are generally used when the size of the target audience is smaller and the goal of technology transfer is more specific, such as the adoption of a newly developed software technology by a utility through a formal exchange. The "cost per exposure" for active transfer methods is much higher because of the aggressive outreach and interaction with target audiences associated with these methods. Active methods are "sourcedriven"; therefore, they are more rapid in disseminating information because of a more aggressive attempt to reach target audiences. Because the source and 
the end-user tend to be very interactive in the technology transfer process, active methods of technology transfer promote better communication.

Table 5.2 identifies specific transfer mechanisms, their perceived advantages and disadvantages, and appropriate situations for the use of each mechanism. This table lists methods of technology transfer from the most passive, in terms of the efforts of those initiating the transfer, to the most active. 
TABLE 5.2. Comparative Advantages of Technology Transfer Mechanisms Ordered from Most Passive to Most Active

Mechon I5ms

1. Publlcotions

2. Informal Interactions

3. Medla Announcements

\section{Qulck}

Wide oudlence

Instant recelpt of message

4. Dota Banks

:

Advantages totion promotes referral

fled audlence

Accesslble to a broad audlence of any tlm

Search Capablilitles

Interagency \& international

capabitities
Tanglble, permanent documen-

cen be tallored to an Ident1-

Technlcal dialogue excellent

MinImal cost or plannIng
Promotes personal Interaction

ro sure dissemination or product

No proof of I mpact

Impact is II kely of short duration

Relatively expensive

LIkely to be superflcial

5. Information DIssemination Centers

Provide responses qulckly "on demand"

islble Information accessibie to oll

Reterence services avallable

6. Technical Meetings/ Exchanges

7. Direct Molling

8. Llaison wth Industry Assoelations
Passiva, must be accessed

Can be inaccurate or

$$
\text { Incomplete }
$$

Mony tImes ore not current

Passive, mast analt requests Qual lty dependent on collec

\section{Norrom audience}

vulnerable to personallty varlables

No proof of 1 mpact

Potential for waste

Requires a selectlve malling

$$
\text { ilst }
$$

Government may become influenced by "In group" and not as responsive to new and innovative technology tion and currency
Specifle tople

Rapld informotion exchange

Minimal cost

Qulck

Relatively Inexpensive

Wide aud lence

Instant recelpt of message

Promotes clear understandling of critlcal Industry concerns

Virtually cost free

Two-way communtcation
Approprlate Situation

Addressing broed large aud lences at later stages of technlcal development

\section{All stoges of technology} development

When there is a need to communicate ith a broad audlence quickly

When a technology is at an active R\&D stage and further development is dependent on data ossimilation and anatysls

\section{Addressing broed large} audlences at later stages of technicel development

When a speclfic problem has been Identifled

When there is a need to commun lcate with a broad oudlence quickly

When commun lcation needs are immad late and constant 
TABLE 5.2. (contd)

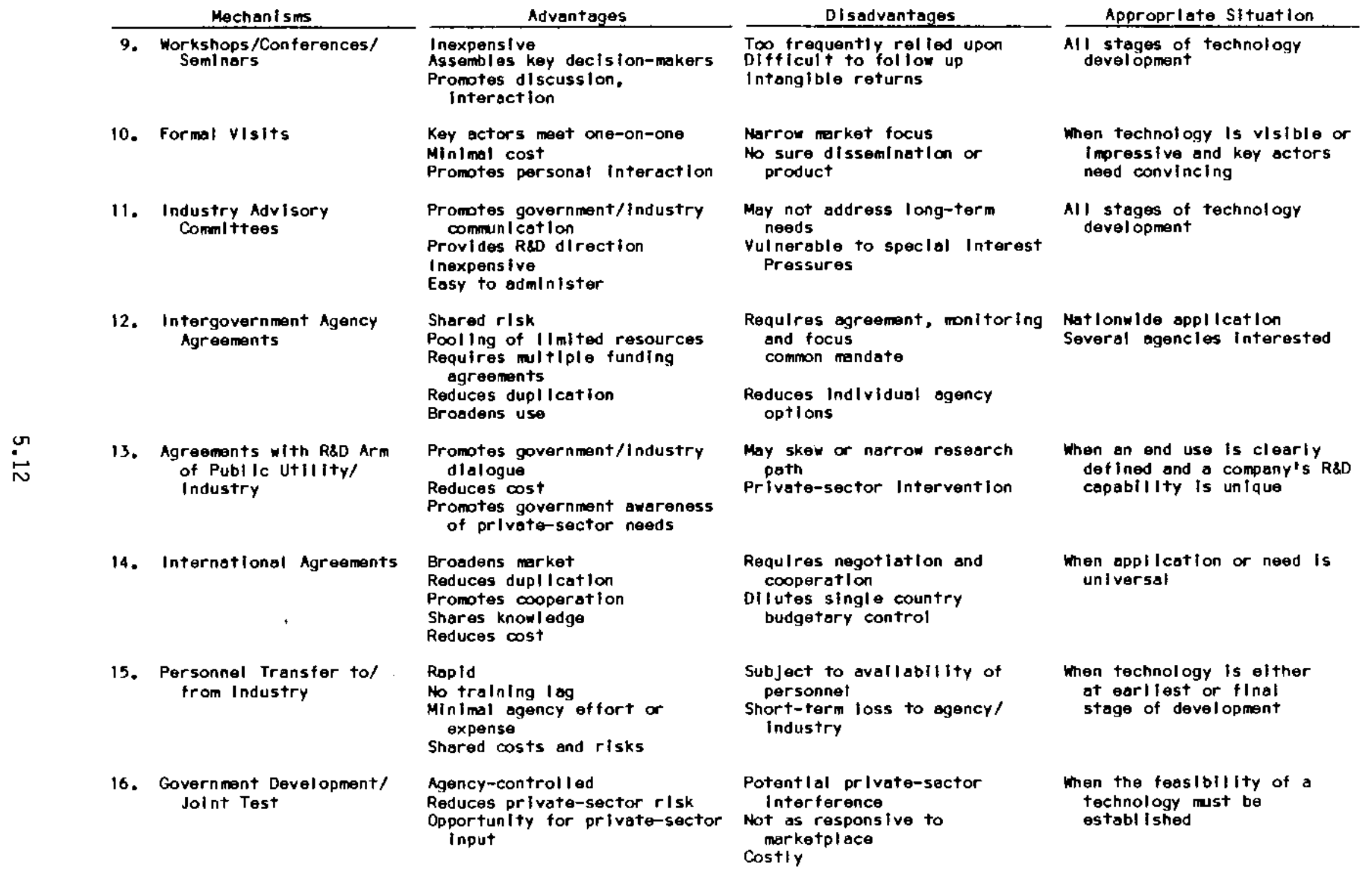


TABLE 5.2. (contd)

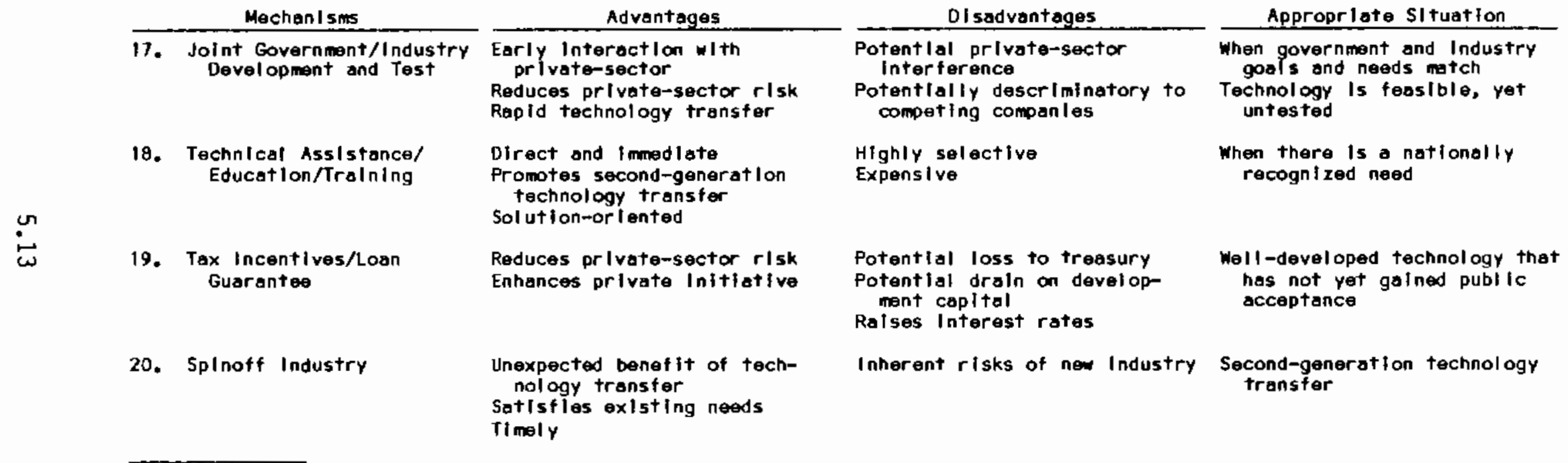

Source: DOE Geothermal and Hydropower Technologles Division, 1984. "Geothermal Technology 5trategy and PIan, FY 1984." 
.

. 


\subsection{CURRENT EES TECHNOLOGY TRANSFER ACTIVITIES AND SUGGESTED IMPROVEMENTS}

As stated previously, the general objective of this study is to develop a set of technology transfer activities that will be both effective in transferring technology and feasible under current EES program resource constraints. To achieve this objective, it is first necessary to describe the current transfer activities and indicate whether they are effectively targeted towards the relevant audiences for the research areas (described in chapter 5), and whether they are appropriate for the nature of the research being conducted (described in Chapter 4). After the current technology transfer activities have been described, suggestions for improvemeits in these activities can be formutated.

The first section of this chapter documents the technology transfer activities that have been conducted in the DOE/EES program over the past two years. The second section suggests improvements in these activities.

\subsection{REVIEW OF DOE/EES TECHNOLOGY TRANSFER ACTIVITIES OVER THE PAST TWO YEARS}

Although the EES program has previousiy not had a formal technology transfer plan, an extensive number of technology transfer activities have been conducted. These activities have been primarily technical interactions between EES program research personnel and their professional peers through publications, conference presentations, site visits, review committees and other activities.

Currently, publications and conference presentations appear to be the most frequently used technology transfer methods within the EES program. It is often difficult to distinguish between these two methods, because a paper given at a conference will often be published in the proceedings of the conference. For this study, a decision was made that any conference papers that were cited as published in the proceedings were designated as publications and all other conference papers not published in proceedings were designated as presentations. The single counting of conference papers reprinted in conference proceedings as publications results in a conservative estimate of the number of presentations. In addition, DOE/EES reports distributed solely to internal audiences were omitted from the publications list because this study concerns 
technology transfer activities involving external audiences. Publications and presentations dated before January 1984 and after January 1986 were also not included in this study because of the two-year time frame of the study.

The information presented in this chapter was developed from surveys of the DOE/EES research project managers (by mail or in-person) and through crosschecking the publications identified in the Program Information Notice for the DOE/EES program. A copy of the survey form used to obtain the information on current EES technology transfer activities is presented in Appendix $C$.

\subsubsection{Electric Field Effects Technology Transfer Activities}

Electric field effects research is the most widely published element of the EES program. A list of the publications and conference presentations by program personnel is presented in Table 0.1 of Appendix 0 . All of the information presented in this section and Appendix $D$ was drawn from interviews with knowledgeable individuals from the electric field effects program.

The publications list for electric field effects includes over 70 publications, 63 in technical/professional journals or technical conference proceedings. The primary professional journals for electric field effects publications are Bioelectromagnetics and Neuroscience Abstracts. The electric field effects program also produced seven publications in magazines of more general industry interest, including Electrical World, Public Utilities Fortnightly, OMNI, and Science.

Electric field effects personnel presented approximately 80 papers at technical conferences over the past two years. The primary conferences included DOE/EPRI Contractor's Review Meetings, Hanford Science Symposiums and the Bioelectromagnetics Society meetings.

A typical distribution list for the electric field effects publications was analyzed for audience composition and is summarized in Figure 6.1. Note that current technology transfer efforts in electric field effects appear to b directed towards professional scientists and representatives of government agencies, which is appropriate given the nature of this research. 


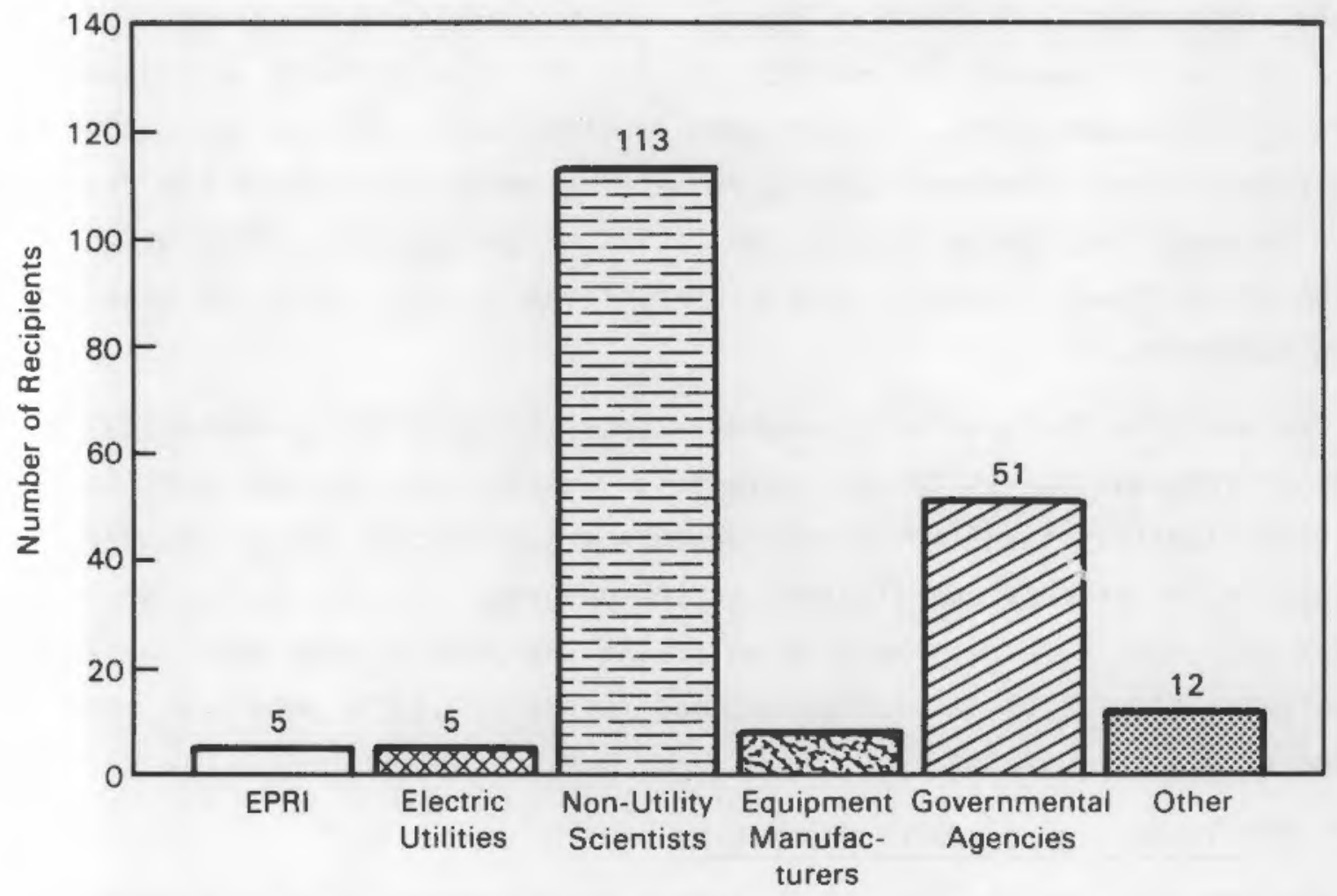

FIGURE 6.1. Composition of Typical Electric Field Effects Distribution

The DOE/EES-sponsored electric field effects research is internationally recognized for its quality and content. A substantial amount of informal contact between electric field effects personnel and foreign peers is undertaken. A formal agreement is currently incorporated in the program for joint funding by Japanese interests of a project being conducted by the Southwest Research Institute.

The electric field effects program coordinates its research with the research efforts of EPRI, which is currently spending $\$ 2.5$ to $\$ 3.5$ million for research on electric and magnetic field effects. A formal committee is in the process of being formed with EPRI to produce even more cooperation and interaction. Informal information exchanges with individual utilities, including Southern California Edison and American Electric Power, have also been used to disseminate information about the program.

The electric field effects program has an interagency advisory committee that includes representatives from the Bonneville Power Administration (BPA) 
and the Environmental Protection Agency. Individuals from the program also have a substantial amount of interaction with state departments of health and public utility commissions. The program receives approximately one letter per month from a state government agency requesting information about the program. In addition, the laboratory facilities of the electric field effects program are visited frequently by representatives of EPRI, BPA, and other target audiences.

The electric field effects program appears to generate a substantial amount of interest in its target audiences. Public interest and court cases involving significant dollar volumes produce a substantial amount of user interest in the process and findings of the program. For the past year, program personnel have been working on making the program even more useful to its target audiences by developing methods for defining the potential risks and hazards of electric fields.

\subsubsection{EMP Technology Transfer Activities}

The EMP research program recorded 13 non-DOE publications in 1984 and 1985. These publications were all technical/professional in nature. Primary journals for these publications were Air Force Weapons Laboratory Interaction Notes and IEEE Transactions. EMP research personnel have also made four conference presentations, primarily at utility power systems conferences. A list of the publications and presentations developed by EMP personnel over the past two years is presented in Table $D .2$ of Appendix D.

The EMP program has agreements with representatives of various European countries to share the knowledge and results of the research. The program also has a pending agreement for sharing equipment with the Defense Nuclear Agency (DNA), and is investigating the possibility of direct sharing of costs with DNA in the future.

EMP research is in its early stages, and consequently has not had as extensive technology transfer activities as have some other research areas within the DOE/EES program. However, the program has had extensive interaction since its inception with Department of Defense components, such as DNA and the Air Force. 


\subsubsection{Normal/Emergency Operating Concepts Technology Transfer Activities}

A list of the 27 publications associated with the normal/emergency operating concepts research program over the past two years is presented in Appendix D, Table 0.3. All of these publications are technical in nature. The most common journal for these publications is the IEEE Transactions. Six conference presentations have been given, mostly at power systems conferences.

One of the most important means of technology transfer for the normal/ emergency operating concepts program is the involvement of program personnel on IEEE committees. An example of these committees is the Dispersed Storage and Generation Standards Committee that was established as EES research in this area was beginning. The standards developed by this committee were directly influenced by EES research results.

Efforts currently being undertaken by McGraw-Edison to transfer technology developed as part of the normal/emergency operating concepts program provide an interesting example of the possibilities for technology transfer when commercial incentives are involved. With the support of DOE/EES, McGraw-Edison developed a computer code for analyzing harmonic distortions in transmission and distribution systems. Significant interest in these programs was evident at the IEEE meetings. Consequently, McGraw-Edison developed a series of seminars to promote the adoption and purchase of the code by utilities.

\subsubsection{Failure Mechanisms Technology Transfer Activities}

The twelve publications and five conference presentations on failure mechanisms research are presented in Appendix D, Table D.4. All of these publications and presentations are technical in nature. The IEEE Transactions was the most frequent medium for failure mechanisms publications. EPRI workshops and American Chemical Society national meetings were among the forums where presentations on failure mechanisms research were given.

Other conferences attended by failure mechanisms research personnel over the last two years included the Insulated Conductors Committee Meeting of the Power Engineering Society and the IEEE Winter Power Meetings. Because of the nature of failure mechanisms research, program personnel are often involved in 
committees and proceedings related to the development of standards for electrical equipment. Program personnel have consulted on committees including the Technical Committee on Failure Mechanisms of the Electrical Insulation Society and the Technical Committee on Insulation Systems of the International Electro-technical Commission.

As is the case for many DOE/EES programs, failure mechanisms research per-sonnel have had a number of interactions with EPRI over the past two years. In some cases, complementary research has been performed for EPRI by failure mechanisms personnel. Program personnel were involved in the development of a press release related to transmission cable research that resulted in a substantial number of meetings and correspondences with European and domestic cable and insulation manufacturers.

Failure mechanisms research supported by DOE/EES provides an interesting example of the spinoff possibilities of some types of research. DOE/EES research techniques for accelerating and predicting failure mechanisms have been used in predicting the service lives of packaging systems for toxic waste materials, nuclear reactor components, and landfill barriers. Thus, the DOE Office of Nuclear Waste Isolation, the Nuclear Regulatory Commission and the Environmental Protection Agency have all been among the indirect beneficiaries of failure mechanisms research.

\subsubsection{HVDC Technology Transfer Activities}

HVDC technology transfer activities over the last two years included the development of five external publications. These publications are listed in Appendix $\mathrm{D}$, Table 0.5 , and include an article pertaining to EES-funded research in IEEE Spectrum. Also listed in Table 0.5 are four conference presentations that were given by HVDC research personnel, primarily at conferences pertaining to the computer-aided design of power systems.

Involvement on the IEEE Power Committee was believed to be a primary vehicle for information dissemination within the HVDC research program. In addition, the HVDC program had an extensive information-sharing agreement with 
the Bonneville Power Administration (BPA) and EPRI in performing research to develop a direct-current circuit breaker for use on BPA's direct-current transmission line.

The DOE/EES HVDC program has had a joint funding agreement with the power agency of New York state to conduct research on 6-phase and 12-phase transmission systems. The program also had one of its research personnel transfer to a major electrical equipment manufacturer for two years to establish a commercial center to promote direct-current technology.

\subsubsection{Automation/Processing Concepts Technology Transfer Activities}

The external publications and presentations related to the automation/ processing concepts research area are presented in Appendix D, Table D.6. There were 10 publications in this area over the last two years, with 7 oriented towards technical audiences and 3 designed to be of more general interest. An Electrical World article on the Athens automation project was included among the general-interest publications. The most frequently used journal for automation/processing concepts publications is the IEEE Transactions.

Typical distribution for an automation/processing concepts publication is shown in Figure 6.2. The information is primarily directed towards utilities, which is appropriate due to the orientation of the automation/processing concepts program towards applied research and model development.

The majority of the 16 presentations by automation/processing concepts personnel were given at general utility industry conferences, such as the American Public Power Association and Edison Electric Institute workshops. Presentations have also been given at various individual utilities, including North Carolina Power and Detroit Edison.

The automation/processing concepts program also includes a personnel transfer among its technology transfer activities. An employee of Baltimore Gas and Electric (BG\&E) is currently working on a two-year assignment to the Athens automated load control project, with his full salary paid by BG\&E during his assignment period. 


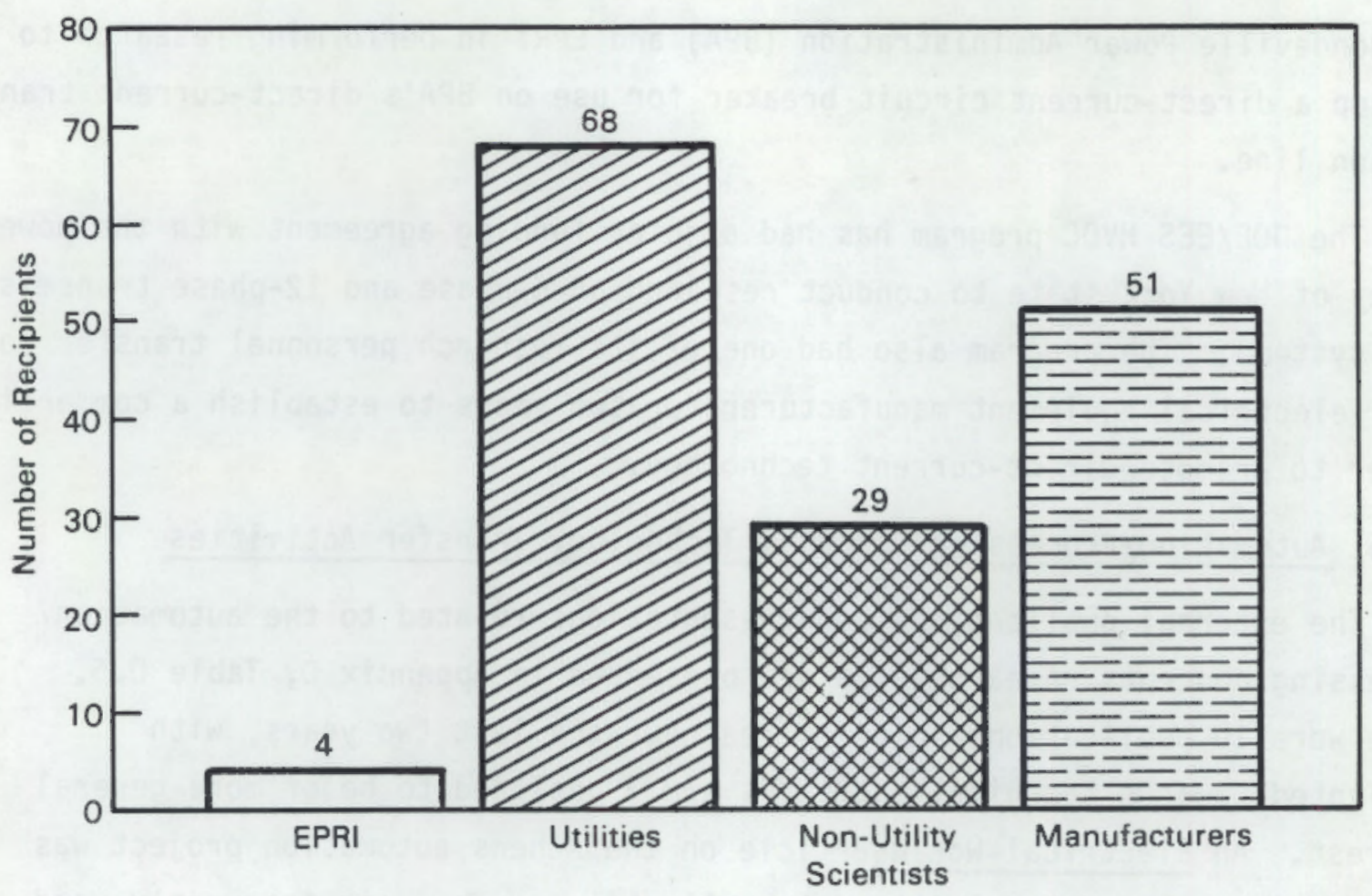

FIGURE 6.2. Composition of Typical Automation/Processing Concepts Distribution

A cost-sharing agreement with EPRI for the Athens project is included in the automation/processing concepts program. Siemans-Allis has also expressed an interest in joint funding of adaptive protection system research. Finally, a VCR tape on the Athens project was developed for use in technology transfer activities.

\subsubsection{New Materials Technology Transfer Activities}

The new materials technology transfer activities in 1984 and 1985 included 36 publications, 31 of which were technically oriented and five of which were of a more general interest. The most frequently used journals for new materials publications were the IEEE Transactions and the Journal of Applied Physics. Transfer activities also included seven conference presentations. Conferences directly sponsored by the new materials research program were frequently used as a means of technology transfer. 
Typical distribution for new materials research is shown in Figure 6.3. This information is primarily directed towards electrical equipment manufacturers, which is appropriate given the nature of the new materials research program.

Other transfer activities within the new materials program include joint testing with EPRI of 1200-kV gas-insulated cables at EPRI's Waltz Mill facility, an international agreement with CIGRE for round-robin testing, and joint funding of research on ambient cable technology with Empire State Electric Energy Research Corporation (ESEERCO), a research organization funded by six private utilities. All research activities of the new materials program are closely coordinated with appropriate EPRI research and task force activities. The program has also won an IR-100 Award, which is awarded annually by Research and Development magazine to the nation's top 100 technical achievements, for its work on development of a zinc-oxide varistor.

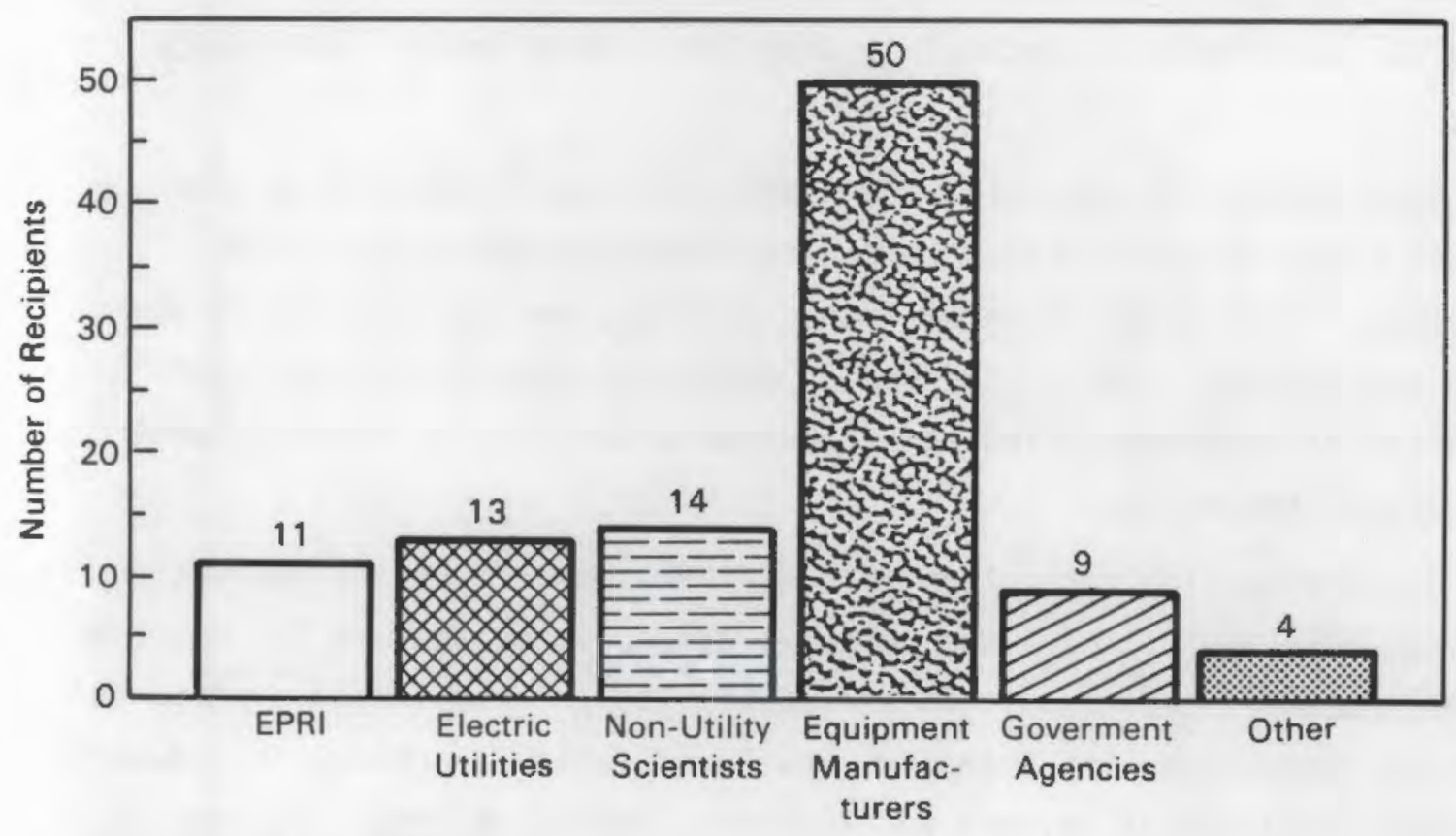

FIGURE 6.3. Composition of Typical New Materials Distribution 


\subsubsection{Superconducting Technology Transfer Activities}

Technology transfer activities in the superconducting technology area over the past two years included six publications and one conference presentation. Further information on these publications and presentations is presented in Table D.8 of Appendix D. All of the listed publications were oriented primarily to technical audiences. Three of the papers listed as publications were published in IEEE Transactions after their presentation at IEEE meetings.

Other technology transfer activities performed as part of the superconducting technology program include a cost-sharing agreement with ESEERCO. This agreement funds the commercial production of an insulated cable developed as part of the superconducting technology research. Cablec Company was selected to manufacture the commercial cable, and superconducting technology personnel were directly involved in transferring information and techniques about the cable to Cablec. As a result of their participation in this program, two indi-viduals from the superconducting technology program were selected to receive an award for excellence in technology transfer from a federal laboratory consortium.

Superconducting technology personnel also participate in a study by Bechtel Corporation to assess the market for superconducting power transmission equipment. This study is being funded by EPRI, two New York state power agencies, and Bechtel, and is intended to determine whether the long-term market potential of superconducting power equipment can justify further commercializa-tion of the technology.

Superconducting technology personnel are members of the Insulating Conducting Committee of the IEEE, which is directly responsible for representing cable industry interests within the IEEE. The program issued a press release entitled "Brookhaven Lab Transfers New Power Cable Technology to Industry" that has been reprinted in several publications, including Power Engineering Review.

\subsubsection{Battery Storage/Load Leveling Research Technology Transfer Activities}

A summary of the the publications and presentations related to battery storage/load leveling research is presented in Appendix D, Table D.9. Five of 
the publications are oriented towards audiences with specific interest in battery storage, whereas two of the publications are in magazines with more general audiences. The publications of more general interest included articles in Modern Power Systems and IEEE Spectrum. Six presentations were given at conferences by battery storage/load leveling research personnel. Power operations technology conferences were the most frequently used forums.

Battery storage/load leveling research personnel have had frequent contact during the last two years with battery manufacturers concerning requirements for applications of battery storage in the utility industry. Research personnel interacted with Exxon, Johnson Controls, Bechtel, SOHIO, Gulf \& Western Industries and others. Activities performed with these groups included the development of a brochure on customer-side-of-the-meter battery energy storage applications, preparation of a design for commercial zinc-chloride battery systems for utilities, and testing of manufacturers' batteries.

Battery storage/load leveling research has attracted a significant amount of international attention, and representatives from many countries have been briefed on the program. Numerous representatives of both domestic and international utilities have toured the Battery Energy Storage Test (BEST) facility. Program personnel have been interviewed by such general interest publications as Fortune and the New York Times in association with articles on battery storage technology.

Battery storage/load leveling research has an information and cost-sharing agreement with EPRI. Program personnel also serve on the IEEE Standards Committee for Dispersed Storage and Generation that is responsible for developing standards for battery energy storage plant applications.

\subsubsection{Hawaii Deep Water Cable Technology Transfer Activities}

The three publications related to the Hawai $i$ Deep Water Cable program in the last two years are shown in Table 0.10 of Appendix D. Activities in this program have focused on informing manufacturers of underwater cables about the progress and results of the research. In addition, a representative of the program attends monthly meetings at EPRI related to research and development of submerged cables. Part of the cost of the Hawaii Deep Water Cable project is 
being paid by the state of Hawaii. In addition, Hawaiian Electric does not charge a fee in excess of its actual costs for any of its work on the project.

\subsection{SUMMARY OF DOE/EES PROGRAM TECHNOLOGY TRANSFER ACTIVITIES}

The activities of the various DOE/EES program elements are summarized in Table 6.1. It can be seen from this table that the program currently incorporates a wide range of transfer activities. The total program includes, in some form, 17 of the 20 identified transfer activities. Most of the individual research areas have utilized over half of the listed transfer activities within the last two years.

Major elements of the DOE/EES technology transfer activities over the last. two years include:

- approximately 190 external publications, of which over $90 \%$ were directed towards technical audiences and subjects

- approximately 130 conference presentations, primarily at IEEE meetings

- numerous site visits

- several advisory committees

- several information- and cost-sharing agreements with EPRI, other government agencies and international governments

- several personnel transfers to and from industry

- several internally sponsored conferences and workshops

- numerous awards and media announcements

\subsection{SUGGESTED IMPROVEMENTS IN CURRENT TECHNOLOGY TRANSFER ACTIVITIES}

The DOE/EES research currently incorporates a wide range of technology transfer activities in its ongoing program. Relatively high-cost activities such as tax incentives, loan guarantees, and sponsorship of spinoff industries 


\section{TABLE 6.1. DOE/EES Technology Transfer Activities in 1984 and 1985}

1. Publications

2. Information Interactions

3. Media or Trade Literature

4. Data Banks

5. Intormation Dissemination Centers

6. Technical Meetings/Exchanges (c)

7. Direct Mailing

8. Liaison with Industry Associations

9. Workshops/Conferences Seminars

10. Formal Visits

11. Industry Review Group

12. Intergovernment Agency Agreements

13. Agreements with R\&D Arm of Public Utility/Industry

14. International Agreements

15. Personnel Transfer to/from Industry

16. Government Development Joint Test

17. Joint Government/Industry Development and Test

18. Spinoff Technology Development ${ }^{(c)}$

\begin{tabular}{|c|c|c|c|c|c|c|c|c|c|c|}
\hline $\begin{array}{c}\text { Total } \\
\text { Program } \\
\end{array}$ & $\begin{array}{l}\text { Electric } \\
\text { Field } \\
\text { Effects }\end{array}$ & $\begin{array}{c}\text { EMP } \\
\text { Impact } \\
\text { Analysis } \\
\end{array}$ & $\begin{array}{c}\text { Normal/ } \\
\text { Emergency } \\
\text { Operating } \\
\text { Concepts } \\
\end{array}$ & $\begin{array}{c}\text { Failure } \\
\text { Mechanisms }\end{array}$ & $\begin{array}{c}\text { HVDC } \\
\text { Research }\end{array}$ & $\begin{array}{c}\text { New } \\
\text { Materials } \\
\text { Research }\end{array}$ & $\begin{array}{c}\text { Super- } \\
\text { Conducting } \\
\text { Technology }\end{array}$ & $\begin{array}{c}\text { Automation } \\
\text { Processing } \\
\text { Concepts }\end{array}$ & $\begin{array}{l}\text { BEST } \\
\text { Load } \\
\text { Leveling }\end{array}$ & $\begin{array}{c}\text { Hawaıl } \\
\text { Deep } \\
\text { Water } \\
\text { Cable }\end{array}$ \\
\hline$x$ & $x$ & $x$ & $x$ & $x$ & $x$ & $x$ & $x$ & $x$ & $x$ & $x$ \\
\hline$x$ & $x$ & $x$ & $x$ & $x$ & $x$ & $x$ & $x$ & $x$ & $x$ & $x$ \\
\hline$x$ & $x$ & & $x$ & & $x$ & & $x$ & $x$ & $x$ & $x$ \\
\hline$\frac{x^{(a)}}{x^{(b)}-}$ & & & & & & & & & & \\
\hline$x$ & $x$ & $x$ & $x$ & $x$ & $x$ & $x$ & $x$ & $x$ & $x$ & $x$ \\
\hline$x$ & & & & & & & & & & \\
\hline$x$ & $x$ & & $x$ & & & $x$ & $x$ & $x$ & $x$ & \\
\hline$x$ & $x$ & $x$ & & $x$ & $x$ & $x$ & $x$ & $x$ & $x$ & \\
\hline$x$ & $x$ & & & & $x$ & & $x$ & $x$ & $x$ & . \\
\hline$x$ & & $\bar{x}$ & & & & $x$ & & $x$ & $x$ & $x$ \\
\hline$x$ & $x$ & $x$ & & & $x$ & & . & & & $x$ \\
\hline$x$ & $x$ & & & & $x$ & $x$ & $x$ & $x$ & $x$ & \\
\hline$x$ & $x$ & $x$ & & $x$ & & $x$ & & & & \\
\hline$x$ & & & & & $x$ & & & $x$ & & \\
\hline$x$ & & & $x$ & & & $x$ & $x$ & & & \\
\hline$x$ & $x$ & & & & & & & $x$ & $x$ & \\
\hline & & $x$ & & $x$ & & $x$ & $x$ & & & \\
\hline
\end{tabular}

(a) DOE/EES program has no internal data bank, but on-line retrieval capability is available through the National Technical Information Service, (b) the Office of Science and Technology Information and Edison Electric Institute.

DOE/EES program has no internal information dissemination center, but copies of reports are disseminated by the National Technical information Service, the Office of Science and Technology Information and individual program managers.

(c) This category includes providing inputs to standards and codes, which is a prominant feature of many DOE/EES research projects. 
are not included. Under the current budget situation these activities are not feasible, and would not appear to constitute an efficient use of DOE/EES resources.

Several DOE/EES program managers indicated that current budget levels are already limiting their technology transfer activities. However, several other managers indicated that limited budgets were not a significant problem in conducting appropriate technology transfer activities, as long as they had enough resources to develop technologies that would be worthy of transfer.

DOE/EES program managers recognize and understand the audiences for their research information. Eximination of the distribution lists for reports in electric field effects, new materials, and automation/processing revealed that the reports were generally directed toward the appropriate audiences. In addition, none of the program managers interviewed in the study stated that audience identification was a significant barrier to their technology transfer activities.

The transfer mechanisms used by the DOE/EES program appear to be relatively complete and to target the right audiences; therefore, the suggested improvements in the program are related more to style than to content. The program has demonstrated a high degree of technical excellence through the extensive publication records of the individuals in the program, through their involvement and direction of technical organizations and activities (particularly with IEEE), and through their academic/industry experience. However, despite these achievements, it does not appear that the program is receiving the recognition it deserves among the industries that could benefit from the results of its research.

One program manager remarked in the field interviews that the DOE/EES research program is not regarded as being of "prominent national stature." Reduced program budgets have contributed to the loss of stature in the program. However, it appears that there are several relatively low-cost activities that the program could undertake to improve its stature and recognition.

One area the EES program could improve upon is its level of publishing in industry trade literature. Of the 190 publications identified as issued by the 
EES program, only about 15 were published in general trade literature that would be likely to reach industry decision-makers. The program had only two articles pertaining to its research in Electrical World, none in Electric Light and Power, none in Power Engineering, and none in Transmission and Distribution. No instances of articles directly citing EES-supported work being published in the EPRI Journal were identified.

In addition, the program should attempt to obtain a more visible presence at industrial trade conferences. IEEE activities are important, but they should not be the only focus of conference activity. Presentations at conferences like the Energy Technology Conference (ETC) and the Transmission and Distribution Exposition will enhance the visibility of the EES program.

The visibility of the program could also be enhanced by more actively researching and disseminating examples of success stories from within the program to industry decision-makers. These examples should start from a basis of DOE/EES-funded research activities, detail how the results of the research were applied to an industrial problem, and describe the benefits of the research as it achieved widespread acceptance.

The DOE/EES program also has no organized internal information center for disseminating information related to the program. The National Technical Information Service (NTIS) and Office of Scientific and Technical Information (OSTI) are assigned information-dissemination functions for the program, but the effectiveness of these organizations with respect to the specific objectives of the program is unclear. It would seem beneficial to investigate the development of an information-dissemination system specific to the DOE/EES program. This system would include a targeted mailing list for informational materials pertaining to DOE/EES research activities.

Although full reports and papers are distributed to appropriate target audiences, the DOE/EES program has no organized system for providing industry decision-makers with sumaries of program information. Full reports can result in "information overload," with a resulting decline in technology transfer effectiveness. The program could consider developing project description sheets to convey the major objectives and results of the various research projects to decision-makers, along with a simple referencing system where the 
decision-makers could obtain more detailed information. These description sheets could be patterned after EPRI's one-page description sheets so that they would be easy to read and use.

According to EES program priorities, the electric field effects and Hawai $i$ deep water cable programs need the least modification in their technology transfer activities. The electric field effects program already receives a substantial amount of attention and interest from utility representatives, regulatory agencies and others. It is the major source of objective information for decision-makers involved with electric field effects, and these decision-makers are actively seeking this information. Thus, less effort is required for technology transfer in relation to the electric field effects program. In addition, obtaining the industry involvement that is desirable for other parts of DOE/EES research may be detrimental to electric field effects research because of the perceived loss of objectivity that may result. The Hawai deep water cable program would appear to be appropriate for a low level of effort in technology transfer because the problem being examined is so localized and specific.

The DOE/EES program should solicit information from industry on an annual basis concerning their perceived long-term research needs and their level of interest in several of the program's ongoing or concluding research projects. A simple information-gathering effort could determine the interest level of industry decision-makers in technologies such as the superconducting generator, automated system software packages, or direct-current control equipment. Once the one or two technologies of most interest were identified, more active technology transfer activities such as video-tape presentations, formal onsite demonstrations and negotiated cost-sharing agreements could be undertaken.

Finally, the DOE/EES program should continue to expand several of the technology transfer activities that it is already conducting. Efforts should be initiated to expand industry involvement in the planning stage of the program. An organized mechanism is needed to obtain input from industry on whether proposed projects are directed towards solving the long-term needs of the nation's transmission and distribution system. This information could be used in designing future research programs. 
The program should continue efforts to interest industry in research cost sharing. Although it is very difficult to convince short-term decision-makers to make expenditures on long-term research, even limited cost sharing of $5 \%$ or less could facilitate the process of technology transfer significantly. In addition, the program should employ industrial firms as contractors or subcontractors on projects whenever possible. The experience with the harmonics software development by McGraw-Edison highlights the improved possibilities for technology transfer when industrial firms are directly involved in the performance of a project.

Personnel transfers from industry should continue, such as the one that is ongoing on the Athens project, involving an employee of Baltimore Gas and Electric. Projects such as Athens, BEST, the MIT superconducting generator and others within the EES program would be natural laboratories for technology transfer through the active involvement of industry personnel. 
, 


\subsection{DOE/EES PROGRAM TECHNOLOGY TRANSFER PLAN FOR THE NEXT TWO YEARS}

Based on the analysis of the DOE/EES program mission, target audiences and current technology transfer activities, a plan was developed to guide the program's technology transfer activities over the next two years. Because of the breadth and depth of current technology transfer activities, no major departures from these activities are planned. However, several additional activities are planned to increase both the visibility of the program and the effectiveness of technology transfer efforts. To insure the ability of the plan to guide future technology transfer efforts, specific task assignments and anticipated dates of completion for each task are presented in this section.

\subsection{TASK ASSIGNMENTS FOR EES PROGRAM TECHNOLOGY TRANSFER ACTIVITIES}

The major elements of the technology transfer activities planned for the next two years are summarized in Table 7.1. Most of the additional program activities will be conducted at the overall program level. These activities include:

- developing a DOE/EES program computer mailing list (organized by program area) that will guide the distribution of all DOE/EES program technology transfer materials

- formatting, editing and distributing one-page project description sheets

- collecting information from industry decision-makers regarding their research needs and priorities

- selecting two or three projects for active technology transfer and coordinating technology transfer activities for the selected projects

- documenting annually the program's technology transfer activities. The mailing list for the program will include individual names, titles, company names, addresses and telephone numbers obtained from program managers, existing reports, and other sources. It will be organized by program area (e.g., electric field effects, EMP, etc.) and be updated on at least an annual basis. 
TABLE 7.1. Summary of Technology Transfer Plan for D0E/EES Program Over the Next Two Years

Progran Element Responsible Individual(s) Overall DOE/EES Program

J. W. Hurwitch/

L. L. Fassbender/

R. M. Smith
Electric Field Effects
Tasks to be Conducted/Coordinated

1 Develop format for one-page project description sheets

Target Dates for Activity Completion

\section{$11 / 86$}

2 Develop EES program mailing list $12 / 86$

3. Coordinate selection of two or three appropriate projects for active transfer

4. Edit and distribute one-page project description sheets and sunmaries

5. Collect information irom industry regarding research needs and priorities

6. Solicit information and document annual technology transfer activities

7. Suggest mechanisms to promote cost sharing, personnel transfer activities for selected projects

1. Continue present technology transfer activities

2. Provide data on projects and technology transfer activities as requested

$3 / 87,3 / 88$

$4 / 87,4 / 88$

$4 / 87,4 / 88$

$6 / 87,6 / 88$

$6 / 87,6 / 88$

3. Provide input for development of one-page project description sheets
$6 / 88$

$4 / 87,4 / 88$

$12 / 86,12 / 87$ 
TABLE 7.1. (contd)

$\begin{array}{ll}\frac{\text { Program Element }}{\text { EMP Impact }} & \text { Responsible Individua } \\ \text { Analysis } & \text { R. Barnes } \\ \begin{array}{l}\text { Hawaij Deep } \\ \text { Water Cable }\end{array} & \text { R. Eaton } \\ \begin{array}{l}\text { Normal/ } \\ \begin{array}{l}\text { Emergency } \\ \text { Operating } \\ \text { Concepts }\end{array}\end{array} & \text { T. Rizy, T. Reddock }\end{array}$

Tasks to be Conducted/Coordinated

Same activities and target dates as for electric field effects

Same activities and target dates as for electric field effects

1. Continue present technology transfer activities

2. Provide data on projects and technology transfer activities as requested

3. Provide input for development of one-page project description sheets

4. Coordinate publication of at least two articles in industry trade literature and two presentations at trade conferences

5. Submit candidate projects for active technology transfer

6. Be available for possible participation in active technology transfer activities such as cost sharing, personnel transfer, etc.
Target Dates for Activity Completion

$12 / 86,12 / 87$

$3 / 87,3 / 88$ 
TABLE 7.1. (contd)

Target Dates for Activity Completion

\begin{tabular}{|c|c|c|}
\hline Program El ement & Responsible Individual(s) & $\begin{array}{c}\text { Tasks to be } \\
\text { Conducted/Coordinated }\end{array}$ \\
\hline $\begin{array}{l}\text { Failure } \\
\text { Mechanisms }\end{array}$ & M. Epstein & $\begin{array}{l}\text { Same activities and target dates } \\
\text { as for Normal/Emergency Operat- } \\
\text { ing Concepts }\end{array}$ \\
\hline HVDC Research & J. Stovall & $\begin{array}{l}\text { Same activities and target dates } \\
\text { as for Normal/Emergency Operat- } \\
\text { ing Concepts }\end{array}$ \\
\hline $\begin{array}{l}\text { New Materials } \\
\text { Research }\end{array}$ & S. Dale & $\begin{array}{l}\text { Same activities and target dates } \\
\text { as for Normal/Emergency Operat- } \\
\text { ing Concepts }\end{array}$ \\
\hline $\begin{array}{l}\text { Superconduct- } \\
\text { ing Technology }\end{array}$ & E. Forsyth & $\begin{array}{l}\text { Same activities and target dates } \\
\text { as for Normal/Emergency Operat- } \\
\text { ing Concepts }\end{array}$ \\
\hline $\begin{array}{l}\text { Automation/ } \\
\text { Processing } \\
\text { Concepts }\end{array}$ & J. Stovall & $\begin{array}{l}\text { Same activities and target dates } \\
\text { as for Normal/Emergency Operat- } \\
\text { ing Concepts }\end{array}$ \\
\hline $\begin{array}{l}\text { Battery Energy } \\
\text { Storage/Load } \\
\text { Leveling } \\
\text { Research }\end{array}$ & J. Hurwitch & $\begin{array}{l}\text { Same activities and target dates } \\
\text { as for Normal/Emergency Operat- } \\
\text { ing Concepts }\end{array}$ \\
\hline
\end{tabular}

Same activities and target dates as for Normal/Emergency Operat-

and target -

ing Concepts

Same activities and target dates as for Normal/Emergency Operating Concepts

gates as for Normal/Emergency Operating Concepts

Operating Concepts 
The one-page description sheets that will de developed for the program will be patterned after EPRI one-page description sheets to provide a consistent format for information transfer. They witl contain summarized information on each project, graphics (where appropriate), and references where more information can be obtained. By distributing only selected information to the various target audiences, the problem of information overload can be reduced.

The information collected from industry on their research needs and priorities will guide the research direction of the program and identify projects with the highest probability for active transfer through cost sharing, personnel transfer, etc. Selected individuals on the program mailing list will be asked to supply industry input.

The current technology transfer activities of DOE/EES program managers (such as attendance at IEEF meetings, technical publications, hosting of site visits, etc.) are a key element of future planned activities. The only activities that program managers will perform in addition to their current activities are as follows:

- provide information for the development of one-page project description sheets according to a standardized format

- coordinate publication of at least two articles in industrial trade magazines and two presentations at industrial trade conferences over the next two years (does not apply to electric field effects, EMP or Hawaij deep water cable programs)

- submit candidate projects for active technology transfer and be available for participation in promoting and organizing active technology transfer efforts for selected projects (also does not apply to electric field effects, EMP or Hawai i deep water cable programs).

\subsection{SUMMARY OF PLANNED EES PROGRAM TECHNOLOGY TRANSFER ACTIVITIES}

Dver the next two years, the DOE/EES program will continue its current technology transfer activities and introduce several new activities designed to improve the program's visibility among its industry audiences. Several of these new activities involve interactions between research program managers and 
the individuals responsible for technology transfer activities for the overall DOE/EES program along a "critical path." The critical paths for selected activities and the expected completion dates for tasks along the critical path's are shown in Table 7.2.

\section{TABLE 7.2. Critical Paths for Selected DOE/EES Technology Transfer Activities from $10 / 1 / 86$ to $10 / 1 / 87$}

\begin{tabular}{|c|c|c|c|}
\hline Activity & \multicolumn{3}{|c|}{ Task Date (a) } \\
\hline $\begin{array}{l}\text { Develop Program } \\
\text { Malling List }\end{array}$ & $\begin{array}{l}\text { PNL Coordinators } \\
\text { Sol lcit Information } \\
\text { for List } \\
(10 / 86)\end{array}$ & $\begin{array}{l}\text { Program Managers } \\
\text { Supply I nformation } \\
(11 / 86)\end{array}$ & $\begin{array}{l}\text { PNL Coordinotors } \\
\text { Develop Malling } \\
\text { LIst } \\
(12 / 86)\end{array}$ \\
\hline $\begin{array}{l}\text { Develop and DIs- } \\
\text { tribute One-Page } \\
\text { ProJect Descrip- } \\
\text { tion Sheets }\end{array}$ & $\begin{array}{l}\text { PNL Coordinators } \\
\text { Develop Standard- } \\
\text { Ized Format } \\
(11 / 66)\end{array}$ & $\begin{array}{l}\text { Program Managers } \\
\text { Submlt Drafts } \\
(12 / 86)\end{array}$ & $\begin{array}{l}\text { PNL Coordinators } \\
\text { Edtt and Distrl- } \\
\text { bute Shoets } \\
(4 / 87)\end{array}$ \\
\hline $\begin{array}{l}\text { Select and } \\
\text { Actlvely Transfer } \\
\text { Several Projects }\end{array}$ & $\begin{array}{l}\text { Program Managers } \\
\text { Submit Candl dates } \\
(12 / 86)\end{array}$ & $\begin{array}{l}\text { PNL Coordl nators } \\
\text { Soll cit I nformat I on } \\
\text { from industry } \\
(3 / 87)\end{array}$ & $\begin{array}{l}\text { Projects } \\
\text { Selected } \\
(4 / 87)\end{array}$ \\
\hline $\begin{array}{l}\text { Document Annual } \\
\text { Technology } \\
\text { Transfer } \\
\text { Activities }\end{array}$ & $\begin{array}{l}\text { PNL Coordinators } \\
\text { DIstrl bute I nfor- } \\
\text { mation Coll lection } \\
\text { Form } \\
(3 / 87)\end{array}$ & $\begin{array}{l}\text { Program Manager } \\
\text { Supply Information } \\
(4 / 87)\end{array}$ & $\begin{array}{l}\text { PNL Coordinators } \\
\text { Document Annual } \\
\text { Actlvitles } \\
(7 / 87)\end{array}$ \\
\hline
\end{tabular}

(a) All tasks Ilsted except the development of a standardlzed format for one-poge description sheets are planned to repeated during the second year of the plan from $6 / 1 / 87$ to $6 / 1 / 88$. 


\section{REFERENCES}

DDE Geothermal and Hydropower Technologies Division. 1984. Geothermal Technology Strategy Plan, FY-1984.

Electric Power Research Institute. 1986. 1986 Research and Development Program Plan. EPRI P-4411-SR. Palo Alto, Californía.

Encyclopedia of Associations. 1986a. 20th Edition, Volume 1, Entry 1253 (NAERC), Gale Research Company.

Encyclopedia of Associations. 1986b. 20th Edition, Volume 1, Entry 1254 (EPRI), Gale Research Company.

Encyclopedia of Associations. 1986c. 20th Edition, Volume 1, Entry 5643 (NRECA), Gale Research Company. Katherine Gruber, Editor.

EPRI Journal, March 1986. Volume II, Number 2. Electric Power Research Institute.

Traeger, Richard K. 1984. "Technology Transfer Revisited." Paper published in the proceedings of a U.S. Department of Energy workshop entitled A Synthes is of Technology Transfer Methodologies. DE85004635. CoNf $-8 \overline{40} 184$. December 1984.

The Wall Street Journal. 1986. "Electric Utilities Find Market Forces Taking More Important Role." Wednesday, February 26, 1986. 
.

. 


\section{APPENDIX A}

DOE/EES PROJECT SUMMARIES 
TABLE A.1. Identification and Sunmary of EES-Supported Research on Electric Field Effects

\section{Principal \\ Project Contact}

Dr. Walter Rogers

Southwest Research

Institute

S. Michealson and

W. Quinlin

V. Laties and

S. Stern

Dr. Charles Ehret Argonne National Laboratory

Dr. W. Ross Adey Jerry L. Pettis

Memorial Veterans Hospital

Delbert L. Lessor PNL
Project Name

Effects of Electric

Fields on Nonhuman

Primates

Biological Research I

Biological Research Il

Circadian Phase Shift Research

Tissue Interaction with Nonionizing Electromagnetic Fields

Computer Modeling of 60-Hz Electric Field Effects

\section{Summary of Project Goals and Methodology}

To assess the impacts of exposure to high-voltage electric fields on nonhuman primates by measuring the threshold levels at which the animals detect or avoid such fields and by evaluating the effects of chronic exposure on operant conditioning tasks and social behavior.

To develop a better understanding of behavioral responses by rats to electric field exposure by evaluating changes in blood endocrine levels resulting from such exposure.

Evaluating the sensitivity of rats to exposure to electric fields as a furction of exposure levels and behavioral patterns.

To investigate the nature of circadian phase shifts caused by exposure to electric fields through laboratory experiments involving the exposure of whitefooted mice and white rats to $60-\mathrm{Hz}$ electric fields.

To evaluate previous findings on the effects of 60-Hz EM fields on tissue responses to hormones, antibodies, and nerve transmitter molecules through experiments with whole animals.

To develop a basis for scaling the electric field exposure levels used in animal laboratory experiments to exposure levels for humans through development of a computer model capable of estimating electric-field and current density distributions for both humans and animals. 
TABLE A.1. (contd)

Principal Project Contact

Larry Anderson

PNL

Harvey Cohen and Dr. Charles Graham Midwest Research lnstitute

Dr. Robert Hebner National Bureau of Standards (NBS)

T. E. Aldrich and C. E. Easterly Oak Ridge National Laboratory (ORNL)

Dr. Granger Morgan Carnegie-Mellon University
Project Name

Biological Effects of of Electric Fields

Immunological and BioChemical Effects of 60-Hz Electric and Magnetic Fields in humans.

\section{AC Electric and Magnetic} Fields

Human Risk Analysis

Risk Assessment Methodology
Summary of Project Goals and Methodology

To identify and quantify the effects on biological systems and functions of exposure to $60-\mathrm{Hz}$ electromagnetic fields through laboratory experiments using large populations or small, experimental animals and biological preparations (cells).

To investigate the effects of $60-\mathrm{Hz}$ electric and magnetic fields on human immunological, biochemical and hematological processes using a $60-\mathrm{Hz}$ human exposure facility, developing a physiology/performance testing procedure, and conducting two research studies on human volunteers.

To provide electrical measurement support for $A C$ electric field effects research by evaluating the performance of probes used in biological experiments and field meters used in the vicinity of transmission lines.

To assess the potential health risks associated with $60-\mathrm{Hz}$ electrofields through development of specific health risk methodologies, preparation of a methodology for possible epidemiology studies, and development of advanced epidemiological techniques.

To develop a methodology for assessing the risks to human health from exposure to $50-$ to $60-\mathrm{Hz}$ electromagnetic fields that will determine the point at which a specific issue in electric field effects has been studied sufficiently. 
TABLE A.1. (contd)

Principal Project Contact

J. L. Simpson and $\mathrm{C}$. Brice

University of

South Carolina

W. G. Wi secup

$W / L$ Associates,

Ltd.

Dr. Gary B. Johnson HVOC Ion Research General Electric

D

Dr. Robert Hebner

NBS

Washington, D.C.
Project Name

Analysis of Tennessee

Valley Authority (TVA)

Electric Field 0ata

Technical Support in Electric Field Effects

DC Fields and Ion Measurement
Summary of Project Goals and Methodology

To develop predictive statistical models of electromagnetic field strengths under transmission lines using field data (topography, weather, line height, load, etc.) collected near TVA's 500-kV transmission lines.

To assure that EES supported research is properly structured and coordinated with other electric field effect research by technically integrating EES research in relation to worldwide biological effects research.

To develop a predictive model on the magnitude of electric-field and charge densities from DC transmission lines by characterizing the electrical environment within and around the HVDC corridor by measuring aerosol charging in experimental and actual transmission facilities.

To develop methods to evaluate instruments used to measure the electric field space charge and current density in the vicinity of HVDC transmission lines to provide researchers with electrical measurement support, and to provide technical information needed to develop measurement standards in the vicinity of HVDC transmission lines. 
TABLE A.2. Identification and Summary of EES-Supported Research on EMP Impact Analys is

\section{Principal \\ Project Contact}

Dr. Robert Hebner NBS

P. R. Barnes

ORNL

$+$
B. W. McConnel 1 ORNL

\section{F. A. Modine} ORNL

P. R. Barnes ORNL

\section{Project Name}

Nanosecond Breakdown in Power Systems

Dielectrics

Research and Development of Power Systems IJnder the Influence of Electromagnetic Pulse.

Corona Modeling

Fast Response Zinc Oxide (Zn0) Varistor Material Development

Nuclear Plant Study Review
Summary of Project Goals and Methodology

Efforts focus on characterizing electrical system component breakdown which results exclusively from fast-rising pulses in order to develop an optical measurement plan for evaluating the impacts of nanosecond rise times applied to electrical power equipment and systems.

To develop technologies which overcome the vulnerability of electric power systems to EMP by coordinating and conducting activities such as development of EMP assessment methodology, a test facility to simulate EMP surges, insulation system investigations, and the impact of corona on EMPinduced surges.

To determine the need for a realistic corona model capable of predicting corona charge around electrical conductors using models, equations and test facility experiments to calculate the effects of corona on propagation velocity and conductor current.

To compare coarse-grained Zno varistors to ultrafine-grained $\mathrm{ZnO}$ varistors developed by ORNL in order to investigate their electrical properties as a function of microstructure. Particular emphasis is being placed on analyzing the response of varistors to very fast electrical pulses.

A previous study which assessed the effects of EMP on commercial nuclear power plant safety systems is being reviewed as the first step toward assessing the effects of EMP on commercial nuclear power plants. 
TABLE A.2. (contd)

Principal Project Contact

Dr. G. Schoefield and Allen Ramrus Maxwell Laboratories

L. Burrage Cooper Industries

T. Lui

in
Project Name

Design Concept for Test Facility to Simulate surges induced by Electromagnetic Pulse (EMP)

Delayed Dielectric Breakdown

Experimental Investigation of Corona

Design Concepts for Test Facility to Simulate Surges Induced by HighAltitude Electromagnetic Pulse (HEMP)

Dr. C. W. Kimblin Westinghouse Electric Company
Design Concepts for a Test Facility to SimuMHD-EMP late Surges Induced by
Summary of Project Goals and Methodology

Development of design concepts for a test facility to simulate fast pulse surges induced by highaltitude MP (HEMP) and slow pulse surges induced by magneto-hydrodynamic-EMP (MHD-EMP).

To evaluate the impact on power systems insulation of impulses of greater or equal magnitude, shorter durations, and faster rise time than presently used for insulation testing by performing a literature search, identifying areas of further investigation, and finaliy by proposing models and experiments.

To experimentally investigate a conductor's response with corona under simulated EMP conditions by conducting tests designed to validate proposed corona models and to determine parameter valves for the models.

To develop design concepts for simulating HEMPinduced fast pulse surges. Concepts include pulseproducing power apparatus, test equipment coupling devices, control systems, data acquisition, and facility requirements.

To develop design concepts for a test facility to simulate MHD-EMP-induced surges. Tasks include concepts for pulsed power apparatus, test equipment coupling devices, data acquisition, control systems and facility requi rements. 
TABLE A.2. (contd)

\begin{tabular}{ll} 
& \multicolumn{1}{c}{ Principal } \\
& Project Contact \\
H. W. Zaininger \\
Zaininger Engineer- \\
ing Company \\
T. Reed \\
Westinghouse \\
Electric Company
\end{tabular}

Electric Company
Project Name

HEMP Interaction with an

Electric Power Distrihution Circuit

Electromagnetic Pulse (EMP) Assessment of Electric Power Systems
Summary of Project Goals and Methodology

To investigate the impacts of HEMP induced surges on electric power distribution circuits.

To assess the electric utility power systems' response to nuclear EMP and to recommend means for protection of these systems under such an occurrence. Electric power systems operating under present procedures and special procedures developed to protect against EMP will be assessed. 
TABLE A.3. Identification and Summary of EES-Supported Research on Normal/Emergency Operating Concepts

Principal Project Contact

\section{J. Zaborsky Washington} University

\section{J. Zaborsky Washington \\ University}

Joe Chow
General Electric
Company

\section{A. Phadke} Virginia Poly.

Technic Institute
E Fuchs University of Colorado, Boulder
System Restoration

On-Line Detection of System Instabilities

On-Line Detection for System Instabilities

Real-Time Measurements in Power Systems
Summary of Project Goals and Methodology

To develop direct mathematical methods for analyzing electric system stability for use in the development of practical methodologies for computer-aided, on-line detection and mitigation of abnormal operations.

To develop strategies for optimal restoration of power after a major system failure that optimizes the control center and its interactions between a computer and operator. Program tasks include information gathering and analysis, restoration plan development and implementation tests.

To develop direct analytical methods for stability analysis of interconnected electric energy systems that are compatible with on-line digital computers.

To develop techniques for calculating the expected benefits of using real-ijme state vector measurement procedures to evaluate bus voltage magnitudes and phase angle. Expected benefits are being evaluated through consideration of elements such as data volume through estimating dynamic models and hierarchical/dynamic states, and through testing realtime algorithms.

Limits for the Harmonic Pollution of Residential Electric Power Systems
To define impact parameters for harmonics produced by solid-state electrical appliances and develop a harmonics model for all passive an active elements of a single-phase and three-phase residential distributions feeder. 
TABLE A.3. (contd)

Principal Project Contact

Paul Hughes

Westinghouse

Electric Corp.

K. Krause and

G. Garies

Purdue University

J. P. Stovall

$\infty$

ORNL

J. P. Stovall

ORNL

R. Fox

ORNL

A. G. Phadke Virginia Poly-

Technic Institute
Project Name

Variable Speed Generator

Special Purpose Power System Simulator

Power System Information Management

Dynamic Security using Real-Time Measurements

Fiber-0ptic Temperature Measurement Technique

Adaptive Transmission Protection System
Summary of Project Goals and Methodology

To examine the technical feasibility of a generator that converts varying mechanical input from wind turbines into a constant frequency and voltage output. Functional testing of the variable-speed generator at an actual test site has been completed and a final report is being prepared.

To develop a hybrid power system simulator to facililitate testing of new power system control techniques and energy-saving technologies without the risk associated with performing experiments on actual power systems.

This program plan serves as a guide to other research and development projects concerned with new computer-aided information management techniques for electric power system.

To develop the theoretical basis for using the realtime phasor measurement technique for on-line supervision and control of system dynamic phenomena and confirm it with dynamic cumulation studies conducted on realistic system configurations.

To investigate the use of fiber-optic sensors as an aid to monitoring the operating conditions of electric power equipment. Such sensors could reduce the required number of sensors and transformer containment penetrations significantly.

To conceptualize an integrative protection systern that is responsible for protection control, alarm, and monitoring of a power system; improves system performance and is compatible with existing protection equipment. 
TABLE A.3. (contd)

Principal

Project Contact

R. Dugan

McGraw Edison

Company

\section{J. D. Birdwel \\ University of \\ Tennessee,}

Knoxville

\section{W. Feero and}

G. Rockefeller

Electric Research and Management

L. Suelzel

Helionetics, Inc.

K. Shaw and

E. Detjen

Shaw and Asso-

ciates, Inc.
Project Name

Computer Simulation

Harmonics Study

Computer-Aided Control System Design

Adaptive Transmission Protection System

Development of a Unique Power Conversion Unit

Adaptive Distribution System Protection
Summary of Project Goals and Methodology

Research has been completed on the analysis and control of harmonic distortion of distribution feeders and on procedures to control the harmonic voltage where harmonic sources are widely dispersed. Technology transfer to the electric utility industry is now under way.

To develop software that use a system-based environment for the analysis and design of control systems. Another purpose of this project is to examine modeling problems in utilizing control system theory in power system models.

To define functional requirements and organization of an adaptive protection system which will take into account system-wide bulk power information by linking relays at different suhstations. Such a system may reduce the number of false trips that remove equipment from service.

To design, develop and test a high-quality, low-cost 5-kW DC-to-AC power inverter that will feed solar photovoltaic cell output to an $A C$ electric power distribution system.

To define the general functional requirements and organization for an adaptive protection system that will adjust to changes in the electric power distribution system such as configuration changes, short circuit conditions, loading, and other time-varying parameters. 
TABLE A.3. (contd)

Principal Project Contact

: S. Ibqual Systems Control, Inc.
Project Name

Protection Schemes for Cogenerators
Summary of Project Goals and Methodology

To study the cost/risk trade-offs of alternate protection schemes for cogenerators and small power producers interconnected to the electric utility distribution system by using a decision analysis assessment method. 
TABLE A.4. Identification and Summary of EES-Supported Research and Failure Mechanisms

Principal Project Contact

T. F. Clark Phoenix Electric

Company

\section{G. Gaines}

Battelle-Col umbus

Laboratories

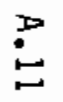

M. Uman and

E. Thompson University of Florida

M. Sosnowski Cable Technology Laboratory
Project Name

Development of Current

Limiting Circuit

Protector

Aging Process in Solid Dielectrics

Analysis of Distribution Lightning Protection System

Threshold and Operating Stresses for HighVoltage Insulating Systems
Sumary of Project Goals and Methodology

To design, develop, manufacture and test currentlimiting circuit protector (CLP) with the ability to limit fault current to $40,000 \mathrm{~A}$ on a $330,000 \mathrm{~A}$ (RMS) fault by using a unique pyrotechnic current commuting scheme.

To study the basic mechanisms of dielectric aging and electrical breakdown in power transmission cables with extruded insulation and to predict the service life of such cables through the development of accelerated test methodologies. This study has been completed except for the dissemination of research results to the electrical insulation community.

To determine the relationship between electric fields and lightning-induced voltages on overhead electric power distribution system structures through examination of present theory and new research involving field measurements and computer analyses.

To determine operating electric stresses for selected high-voltage insulation systens and to develop a test method for varifying threshold voltage levels above which partial discharges appear in the insulation system. 
TABLE A.5. Identification and Summary of EES-Supported Research on High-Voltage Direct Current

Principal Project Contact

P. A. Gnadt and J. P. Stovall ORNL

J. P. Stovall ORNL

D. Carroll and

C. Ong

Purdue University

?

Dr. J. R. Stewart Power Technologies Inc.

\section{W. Long University of Wisconsin}

W. South and John Cooper Westinghouse Electric Cord.
Project Name

Research and Development for High-Voltage Direct Current

Comparison of Costs and Benefits for $D C$ and $A C$ Transmission

HVDC Control Concepts

High Phase Order Transmission

Systen Studies for HVDC Power Transmission

Installation and Testing of the 1200-kV DOE Semiflex CGIT Cable
Summary of Project Goals and Methodology

To further the advancement and direction of HVDC transmission system research in order to lead to more widespread and efficient use of HVDC for the nation's benefit. This project serves a management role to otber HVDC projects.

To identify instances where HVDC is economically superior in electric utility systems by comparing the costs associated with applying HVDC technology versus standard $\mathrm{AC}$ technology.

To simulate new HVDC control concepts and investigate their technical feasibility and potential $A C / D C$ system benefits. Steady-state dispatching and dynamic network flow cr.itrol are also being investigated.

To experimentally verify analytical models of highphase-order AC transmission lines, develop further analytical tools, develop insulators, and demonstrate 12-phase AC operation in a real-world situation

To better understand the economics and performance of integrated $A C / D C$ power systems through the development of new modeling and design techniques. The main task of this project is to develop new techniques for modeling integrated $A C / D C$ power transmission systems.

To install a previously developed $360 \mathrm{ft} 1200-\mathrm{kV}$ semiflex power cable at EPRI's Waltz Mill Test Facility and subject it to long-term life tests. 
TABLE A.5. (contd)

Principal Project Contact

M. Duyang General Electric Company

点

P. Bolin Westinghouse Electric Corp.
Project Name

Technical Feasibility

Study of an HVDC

Compressed Gas Insulated

Transmission Line

Technical Feasibility

Study of an HVDC

Compressed Gas Insulated

Transmission Line
Summary of Project Goals and Methodology

This project supplements previous work done on HVDC $\mathrm{SF}_{6}$ cable. It will demonstrate particle-scavenging procedures using a cycling DC voltage, review and recommend improvements for gas-insulated cable test methodologies, and demonstrate testing procedures using a $\pm 600-k v$ prototype gas-insulated transmission line.

To develop HVDC gas-insulated cavle and substation equipment, test methodologies, and to demonstrate the feasibility of a 550-kV AC semiflexible compressed gas insulated cable design for HVDC application. 
TABLE A.6. Identification and Sumary of EES-Supported Research on New Materials

\section{Principal}

Project Contact

E. R. Forsyth

Brookhaven National

Laboratory

Dr. Robert Hebner NBS

$\stackrel{\sim}{\rightarrow}_{\infty} \quad$ Dr. Robert Hebner

S. J. Dale

ORNL

\section{Project Name}

Fully Synthetic Dielec-

tric Tape Development

Gaseous Dielectrics Research

Interfacial Phenomena in Liquids

Research and Development of Dielectric Materials for Electric Ittility

Equipment
Summary of Project Goals and Methodology

To develop optimized polymeric film tapes for possible use in flexible $A C$ superconducting power transmission cables and underground high-voltage cables. Candidate polyfolefins are being evaluated with regard to their chemical, physical and electrical characteristics.

To develop measurement capabilities and provide fundamental data for the development and evaluation of advanced-compressed-gas insulation technology by directing research toward insulation performance techniques, corona characterization, gaseous dielectrics, and effects of contaminants on discharges.

To develop techniques to measure the electrical behavior of liquid-solid composite insulation for of high-voltage system application. Tasks include measuring the effects of varying contaminants and temperature upon the electric field near the interface of a solid-liquid insulation system.

To develop improved dielectric materials that will reduce life-cycle costs and increase the reliability and efficiency of electric power systems. This objective will be met by managing and conducting research directed towards generating a fundamental understanding of dielectric materials, developing dielectric materials ar.d concepts, and by providing for technology transfer of the new materials and concepts to the electric power industry. 
TABLE A.6. (contd)

Principal

Project Contact

S. J. Dale

ORNL

C. R. Brinkman and

H. E. McCoy

ORNL.

L. G. Christophorou ORNL

它
R. Lauf and

R. K. Williams

ORNL.
Project Name

Conducting Polymer

Research for Power

Equipment Application

Evaluation of Polymers

for Electric Insulation

Gaseous and Liquid

Dielectric Research
Summary of Project Goals and Methodology

To explore the technical and economic feasibility of using conducting polymers as replacements for carbon hlack-loaded materials in power equipment where ability to withstand electrical stress is an essential ingredient of the design.

To characterize the mechanical, electrical and thermal properties of polymers suitable for use as dielectric materials and perform multifactor aging and long-term degradation studies in a number of dielectric liquid and gas environments.

To improve the understanding and use of practical gas and liquid insulation systems. Research includes studying the rroton process in certain gas discharges, the development of improved dielectrics, the development of improved dielectrics, research on inhibiting insulation breakdowns and smali-scale simulation of practical conditions for breakdown tests.

Development of Advanced Metal Oxide Materials
To develop and characterize fine-grained zinc-oxide $(\mathrm{ZnO})$ varistors and better understand their properties, especially how they are affected by processing methods. Investigations include synthes is of highly active powders by sol-gel or coprecipitation techniques, processing studies and testing the electrical characteristics of previously developed samples. 
TABLE A.6. (contd)

Principal Project Contact

D. M. Kroeger ORNL

T. L. Ferrell

ORNL

M. Maskikian University of Connecticut

G. L. Wilson and J. L. Smith, Jr. Massachusetts Institute of Technology

\section{Project Name}

Development of Amorphous Ferromagnetic Alloy for Transformers and Motors

Solid Dielectric and and Interfacial Breakdown

Interfacial Aging Phenomena in Power Cable Insulation Systems

Advanced Concept SuperConducting 10 MVA Generator
Summary of Project Goals and Methodology

The development of ferromagnetic alloys for potential use in transformers and motors that do not possess the brittle characteristics of currently produced alloys. Current efforts seek to define the sites within the alloys that are affected by impurities and determine the compositional dependence of adding small amounts of elements to prevent annealing embrittlement.

To form an understanding of dielectric breakdown at the electrode/solid insulator interface for the highest electric field strengths practical. Experiments will utilize techniques of submicron, surface and condensed matter physics.

To better understand the role of semiconducting shields on changes in polyethylene insulation and to determine the factors that contribute to cable insulation aging. This project will study certain currently used cable materials and will conduct aging tests on these samples.

To develop advanced concepts for super-conducting electric generators. These concepts are being verified through the use of an experimental 10 MVA synchronous generator and will be tested under fullload operating conditions interconnected to a utility system for 30 days. 
TABLE A.7. Identification and Summary of EES-Supported Research on Superconducting Technology

\begin{tabular}{|c|c|c|}
\hline $\begin{array}{c}\text { Principal } \\
\text { Project Contact }\end{array}$ & Project Name & Summary of Project Goals and Methodology \\
\hline $\begin{array}{l}\text { E. B. Forsyth } \\
\text { Brookhaven National } \\
\text { Laboratory }\end{array}$ & $\begin{array}{l}\text { Synthet ic Tape } \\
\text { Development }\end{array}$ & $\begin{array}{l}\text { To perform a full engineering evaluation of a } \\
\text { previously developed prototype ambient temperature } \\
\text { cable with full wall synthetic tape insulation. }\end{array}$ \\
\hline $\begin{array}{l}\text { E. B. Forsyth } \\
\text { Brookhaven National } \\
\text { Laboratory }\end{array}$ & $\begin{array}{l}\text { AC Superconducting } \\
\text { Power Transmission } \\
\text { Cable Development }\end{array}$ & $\begin{array}{l}\text { Development of an underground superconducting power } \\
\text { transmission system ( } 138 \mathrm{kV}, 4000 \mathrm{~A}) \text { capable of } \\
\text { carrying very large blocks of electric power. This } \\
\text { system is based upon a flexible cable employing a } \\
\text { N6 }{ }_{3} \text { S superconductor and an insulation system con- } \\
\text { sisting of synthetic tape impregnated with super- } \\
\text { critical helium refrigerant. }\end{array}$ \\
\hline $\begin{array}{l}\text { S. D. Umans } \\
\text { Massachusetts } \\
\text { Institute of } \\
\text { Technology }\end{array}$ & $\begin{array}{l}\text { Advanced Concept Super- } \\
\text { Conducting } 10 \mathrm{MVA} \\
\text { Generator }\end{array}$ & $\begin{array}{l}\text { To assess the performance of an experimental } 10 \text { MVA } \\
\text { synchronous generator by performing generator cool- } \\
\text { ing system tests, of f-line steady state electrical } \\
\text { tests, full-load tests, and transient electrical } \\
\text { tests. }\end{array}$ \\
\hline
\end{tabular}


TABLE A.8. Identification and Summary of EES-Supported Research on Automation/Processing Concepts

Principal Project Contact

F. Wu and

P. Variaya

University of

California at

Berkeley

G. Mealy

The Analytic

Sciences Corpora-

$t i o n$ (TASC)

$\overbrace{\infty}^{\infty}$

\section{J. Kassakian Massachusetts \\ Institute of \\ Technology}

Dr. James Momoh

Howard IJniversity
Project Name

Disturbance Recognition and System Impact

Evaluation

Disturbance Recognition and System Impact

Evaluation

A New Method of Simulating Static Energy Conversion and Control Systems

Laboratory Development and Power System Optimization Research Program
Summary of Project Goals and Methodology

To develop analytical methods for identifying and evaluating major disturbances and induced system changes in transmission and distribution systems. Tasks include "on-line recognitions of major disturbances," and "key indicators of trends in abnormal operations."

To develop analytical methods for identifying and evaluating major disturbances and induced system changes. The four-part approach includes:

1) Determine number of levels of control necessary by considering decentralized power system structures; 2) Compute sensitivity coefficients by using the "adjoint network" to estimate disturbanceinduced changes; 3 ) Interview system operators to help identify key indicators; 4) Incorporate prior experience to help compute the indicators.

To develop a better understanding of the interaction between the electrical generating source and its transmission/distribution system through the deve1opment of a "parity simulator" of complex systems that permits the addition or removal of critical elements and the ability to change their values during an automated system investigation.

To develop a laboratory facility to simulate complex power systems for conducting research to enhance power system reliability. 
TABLE A.8. (contd)

Principal Project Contact

K. Kirkham

NASA Jet Propulsion

Laboratory

J. M. King

United Technologies

Incorporated

S. L. Purucker

ORNL

$i_{0}$
Brown Boveri

Control Systems, University

of Tennessee

\section{L.0. Monteen and}

N. Fortson

Athens Jtility

Board

\section{R. Dugan}

McGraw-Edison

Company

Summary of Project Goals and Methodology

Communications and

Control for Electric

Power Systems

Advance Converter

Technologies

Athens Automation and Control Experiment (AACE)

Athens Utility Board Activities

Switching Transient and Harmonics Study
To better utilize new information technologies in electric power systems. Current research efforts concentrate on the development of fiber optic measurement and communication systems for power system use.

To define a multimagnetic grid-connected power conditioner that incorporates advanced components and systems technology. A two-bridge high-switching frequency converter system has been defined and a preliminary design produced.

To develop hardware/software computer control technologies for use in the automated management of electric power distribution networks. This project oversees all Athens Experiment-related studies.

To install all hardware and ready the Athens Utility Board (AUD) for operation of the Athens Automation and Control Experiment, which is a computerized hierarchy that operates and controls an electrical distribution system from a central location.

To determine recommendations for capacitor sizes, replacements, and operating systems for feeder switches, plus study the adequacy of switching equipment and current transient protection hardware in support of the reactive power control experiment and the system reconfiguration experiment on the Athens Utility Board. 
TABLE A.9. Identification and Summary of Recent EES Research on Load Leveling

Principal

Project Contact

\section{Al Pivec}

Public Service

Electric and Gas

Company

iñ
T. E. Sharp

Public Service Electric and Gas

Company

Peter Carr

Energy Development

Associates
Project Name

Battery Energy Storage

Test (BEST) Facility

Technical and Economic Assessment of Electrochemical Energy Storage Systems

Zinc Chloride BEST Battery
Summary of Project Goals and Methodology

To provide for the continued operation of the BEST

facility, which is a national center for testing and evaluating advanced battery energy storage systems and associated AC-DC power conversion equipment .

To provide a comparison of the degrees of flexibility in operation, ultimate costs, and environmental safety impacts among advanced batteries.

To produce a zinc-chloride advance battery for use in load-leveling applications by utilities or their customers. A prototype was developed and tested, test results and a summary report are being compiled. 
TABLE A.10. Identification and Summary of EES-Supported Research on Hawaii Deep Water Cable (HDWC)

Principal Project Contact

William Bonnet

Hawailan Electric

Project Name

HDWC (Phase II)

Company, Inc.

C. Traugh II

VSE Corporation

HDWC Technical Support

Summary of Project Goals and Methodology

To determine the technical and economic feasibility of a submarine cable power system between the islands of 0ahu and Hawai i. Factors such as repair, deployment and retrieval at extreme depths and distances will be explored.

To assist EES in the management of the HDWC program by providing engineering and administrative support in areas such as program cost and progress, technical evaluations of designs and concepts, and technical assessments of at-sea routes and cable longevity. 
.

-

.

: 


\section{APPENDIX B}

DOE/EES PRGJECT CHARACTERIZATION MATRICES 
Table B.1. Characterization Matrix for Electric Field Effects Projects

\begin{tabular}{|l|l|l|l|l|l|}
\hline \multicolumn{1}{|c|}{ Stage of R\&D } \\
$\begin{array}{l}\text { Technology } \\
\text { Application }\end{array}$ & $\begin{array}{l}\text { Basic } \\
\text { Research }\end{array}$ & $\begin{array}{l}\text { Applied } \\
\text { Research }\end{array}$ & $\begin{array}{l}\text { Exploratory } \\
\text { Development }\end{array}$ & $\begin{array}{l}\text { Engineering } \\
\text { Development }\end{array}$ & Demonstration \\
\hline $\begin{array}{l}\text { Scientific } \\
\text { Information/ } \\
\text { Technology Base }\end{array}$ & 2,4 & $1,7,11$ & & & \\
\hline $\begin{array}{l}\text { Models and } \\
\text { Analylical } \\
\text { Devices }\end{array}$ & $9,10,14$ & $5,8,13$ & & & \\
\hline $\begin{array}{l}\text { New } \\
\text { Technology }\end{array}$ & & & & & \\
\hline
\end{tabular}

\begin{tabular}{|c|c|}
\hline Project Number & Project Name \\
\hline $\begin{array}{c}1 . \\
2 . \\
3 . \\
4 . \\
5 . \\
6 . \\
7 . \\
8 . \\
9 . \\
10 . \\
11 . \\
12 . \\
13 . \\
14 .\end{array}$ & $\begin{array}{l}\text { Effects of Electric Fields on Non-Human Primates } \\
\text { Circadian Phase Shift Research } \\
\text { Biological Research } \\
\text { Tissue Interaction with Non-Ionizing Electromagnetic Fields } \\
\text { Computer Modeling of } 60-\mathrm{Hz} \text { Electric Field Effects } \\
\text { Biological Effects of Electric Fields } \\
\text { Immunological and Biochemical Effects of } 60-\mathrm{Hz} \text { Electric and } \\
\text { Magnetic fields in Humans } \\
\text { AC Electric and Magnetic Fields } \\
\text { Human Risk Analysis } \\
\text { Risk Assessment Methodology } \\
\text { Analysis of TVA Electric Field Data } \\
\text { Technical Support in Electric Field Effects (a) } \\
\text { HVDC Ion Research } \\
\text { DC Fields and Ion Measures }\end{array}$ \\
\hline
\end{tabular}

(a) This project's objective is to provide technical support to all Electric Field Effects programs in terms of coordination, structure, and information dissemination; it conducts research, and thus is not categorized.

Source: Field interviews with Larry Anderson, Pacific Northwest Laboratory; and Dr. Bill Wisecup, W/L Associates Ltd. 
TABLE B.2. Characterization Matrix for EMP Impact Analysis Projects

\begin{tabular}{|l|l|l|l|l|l|}
\hline \multicolumn{1}{|c|}{$\begin{array}{c}\text { Stage of R\&D } \\
\text { Technology } \\
\text { Application }\end{array}$} & $\begin{array}{l}\text { Basic } \\
\text { Research }\end{array}$ & $\begin{array}{l}\text { Applied } \\
\text { Research }\end{array}$ & $\begin{array}{l}\text { Exploratory } \\
\text { Development }\end{array}$ & $\begin{array}{l}\text { Engineering } \\
\text { Development }\end{array}$ & Demonstration \\
\hline $\begin{array}{l}\text { Scientific } \\
\text { Information/ } \\
\text { Technology Base }\end{array}$ & $7 \leftarrow \begin{array}{c}7,5,6 \\
9,10\end{array}$ & 8 & & \\
\hline $\begin{array}{l}\text { Models and } \\
\text { Analytical } \\
\text { Devices }\end{array}$ & 3 & 11 & & & \\
\hline $\begin{array}{l}\text { New } \\
\text { Technology }\end{array}$ & 4 & & & & \\
\hline
\end{tabular}

Project Number

1.

2.

3.

4.

5.

6.

7.

8.

9.

10.

11.
Project Name

Nanosecond Breakdown in Power System Dielectrics

Research and Development of Power Systems Under the In luence Corona Modeling

Fast-Response Zinc Oxide (ZnO) Varistor Material Deve opment Nuclear Plant Study Review

Design Concepts to Simulate Surges Induced by EMP

Delayed Dielectric Breakdown

Experimental Investigation of Corona

Design Concepts to Simulate Surges Induced by High-Altitude EMP

Design Concepts to Simulate Surges Induces by High-Alt'tude MHD EMP

Electromagnetic Pulse Assessment of Electric Power Systems

(a) This project's objective is to manage and oversee all other projects in EMP Impact Analysis research, and thus was not categorized.

Source: Field interview with Paul R. Barnes, Oak Ridge National Laboratory 
TABLE B.3. Characterization Matrix for Normal/Emergency Operating Concepts Projects

\begin{tabular}{|l|l|l|l|l|l|}
\hline $\begin{array}{c}\text { Stage of R\&D } \\
\text { Technology } \\
\text { Application }\end{array}$ & $\begin{array}{l}\text { Basic } \\
\text { Research }\end{array}$ & $\begin{array}{l}\text { Applied } \\
\text { Research }\end{array}$ & $\begin{array}{l}\text { Exploratory } \\
\text { Development }\end{array}$ & $\begin{array}{l}\text { Engineering } \\
\text { Development }\end{array}$ & Demonstration \\
\hline $\begin{array}{l}\text { Scientific } \\
\text { Information/ } \\
\text { Technology Base }\end{array}$ & $8,13,15$ & 4 & 17 & & \\
\hline $\begin{array}{l}\text { Models And } \\
\text { Analytical } \\
\text { Devices }\end{array}$ & 1,2 & $\begin{array}{r}\checkmark \\
17\end{array}$ & $3,5,10$ & 11 & \\
\hline $\begin{array}{l}\text { New } \\
\text { Technology }\end{array}$ & & 9 & 6 & 7,14 & \\
\hline
\end{tabular}

Project Number

1 .

2.

3 .

4 .

5.

6.

7.

8 .

9.

10.

11.

12.

13.

14.

15.

16.

17.
Project Name

On-line Detection for System Instabilities - John Raborszky System Restoration On-line Detection of System Instabilities - Joe Crow Real-Time Measurement in Power Systems Limits for the Harmonic Pollution of Residential Electric Power

Variable-Speed Generator

Special-Purpose Power System Simulator

Power System Information Management

Fiber-Optic Temperature Measurement Technique

Adaptive Transmission Protection System

Computer Simulation Harmonies Study

Computer-Aided Control System Design

Adaptive Transmission System Protection

Development of a Unique Power Conversion Unit

Adaptive Distribution System Production

Protection Schemes for Cogenerators

Lightning Protection Systems

Source: Field interviews with Tom Rizy, Oak Ridge National Laboratory and Thomas Reddoch, Electrotek Concepts, Inc. 
TABLE B.4. Characterization Matrix for Failure Mechanisms

\begin{tabular}{|l|l|l|l|l|l|}
\hline \multicolumn{1}{|c|}{ Stage of R\&D } \\
$\begin{array}{l}\text { Technology } \\
\text { Application }\end{array}$ & $\begin{array}{l}\text { Basic } \\
\text { Research }\end{array}$ & $\begin{array}{l}\text { Applied } \\
\text { Research }\end{array}$ & $\begin{array}{l}\text { Exploratory } \\
\text { Development }\end{array}$ & $\begin{array}{l}\text { Engineering } \\
\text { Development }\end{array}$ & Demonstration \\
\hline $\begin{array}{l}\text { Scientific } \\
\text { Information/ } \\
\text { Technology Base }\end{array}$ & 1,3 & & & \\
\hline $\begin{array}{l}\text { Models and } \\
\text { Analytical } \\
\text { Devices }\end{array}$ & $2 \leftarrow-7$ & -2 & & 4 & \\
\hline $\begin{array}{l}\text { New } \\
\text { Technology }\end{array}$ & & & & & \\
\hline
\end{tabular}

Project Number

1.

2.

3.

4.
Project Name

Threshold and Operating Stresses for High-Voltage Insulating Systems Aging Process in Solid Dielectrics

Analysis of Distribution Lightning Protection Systems Development of a Current-Limiting Circuit Protector 
TABLE B.5. Characterization Matrix for HVDC

\begin{tabular}{|c|c|c|c|c|c|}
\hline $\begin{array}{l}\text { Stage of R\&D } \\
\text { Technology } \\
\text { Application }\end{array}$ & $\begin{array}{l}\text { Basic } \\
\text { Research }\end{array}$ & $\begin{array}{l}\text { Applied } \\
\text { Research }\end{array}$ & $\begin{array}{l}\text { Exploratory } \\
\text { Development }\end{array}$ & $\begin{array}{l}\text { Engineering } \\
\text { Development }\end{array}$ & Demonstration \\
\hline $\begin{array}{l}\text { Scientific } \\
\text { Information/ } \\
\text { Technology Base }\end{array}$ & & $2,7,8$ & & & \\
\hline $\begin{array}{l}\text { Models and } \\
\text { Analytical } \\
\text { Devices }\end{array}$ & $5 \leftarrow$ & $\rightarrow 5$ & & & \\
\hline $\begin{array}{l}\text { New } \\
\text { Technology }\end{array}$ & & & 6 & 4 & \\
\hline
\end{tabular}

\section{Project Number}

1.

2.

3.

4.

5.

6.

7.

8.

\section{Project Name}

Research and Development of HVDC (a)

Comparison of Costs and Benefits for DC and AC Transmission HVDC Control Concepts

High-Phase-Order Transmission

Systems Studies for HVDC Power Transmission

Installation and Testing of the 1200-KV DOE Semiflexible CGIT Cable

Technical Feasibility Study of an HVDC Compressed Gas Insulated Transmission Line

Technical Feasibility Study of an HVDC Compressed Gas

Insulated Transmission Line

(a) This project's objective is to manage and oversee all other projects in HVDC research and thus was not categorized.

- Source: Field interview with John Stovall, Oak Ridge National Laboratory. 
TABLE B.6. Characterization Matrix for New Materials

\begin{tabular}{|l|l|l|l|l|l|}
\hline \multicolumn{1}{|c|}{$\begin{array}{c}\text { Stage of R\&D } \\
\text { Technology } \\
\text { Application }\end{array}$} & $\begin{array}{l}\text { Basic } \\
\text { Research }\end{array}$ & $\begin{array}{l}\text { Applied } \\
\text { Research }\end{array}$ & $\begin{array}{l}\text { Exploratory } \\
\text { Development }\end{array}$ & $\begin{array}{l}\text { Engineering } \\
\text { Development }\end{array}$ & Demonstration \\
\hline $\begin{array}{l}\text { Scientific } \\
\text { Information/ } \\
\text { Technology Base }\end{array}$ & $\begin{array}{l}2,3,5,6, \\
9,11,12, \\
13,14\end{array}$ & & & & \\
\hline $\begin{array}{l}\text { Models and } \\
\text { Analytical } \\
\text { Devices }\end{array}$ & & & & & \\
\hline $\begin{array}{l}\text { New } \\
\text { Technology }\end{array}$ & 7,8 & 1,10 & & & \\
\hline
\end{tabular}

Project Number
1.
2.
3.
4.
5.
6.
7.
8.
9.
10.
11.
12.
13.
14.

\section{Project Name}

Fully Synthetic Dielectric Tape Development Gaseous Dielectric Research Interfacial Phenomena in Liquids Research and Development of Dielectric Materials for Electric Equipment ${ }^{(a)}$ Evaluation of Polymers for Electric Insulation Gaseous and Liquid Dielectrics Research Development of Advanced Metal Oxide Materials Development of Amorphous Ferromagnetic Alloy for Transformers and Motors Solid Dielectric and Interfacial Breakdown Interfacial Aging Phenomena in Power Cable Insulation Systems Investigation of Interfacial Phenomena Breakdown Studies in Liquid Dielectrics Gaseous Dielectric Toxicity Studies HVDC Don Chemistry

(a) This project's objective is to manage and oversee all other projects in Now Materials research, and thus was not categorized.

Source: Field interview with S. J. Dale, Oak Ridge National Laboratory. 
TABLE B.7. Characterization Matrix for Superconducting Technology

\begin{tabular}{|c|c|c|c|c|c|}
\hline $\begin{array}{l}\text { Stage of R\&D } \\
\text { Technology } \\
\text { Application }\end{array}$ & $\begin{array}{l}\text { Basic } \\
\text { Research }\end{array}$ & $\begin{array}{l}\text { Applied } \\
\text { Research }\end{array}$ & $\begin{array}{l}\text { Exploratory } \\
\text { Development }\end{array}$ & $\begin{array}{l}\text { Engineering } \\
\text { Development }\end{array}$ & Demonstration \\
\hline $\begin{array}{l}\text { Scientific } \\
\text { Information/ } \\
\text { Technology Base }\end{array}$ & & & & & \\
\hline $\begin{array}{l}\text { Models and } \\
\text { Analytical } \\
\text { Devices }\end{array}$ & & & 3 & & \\
\hline $\begin{array}{l}\text { New } \\
\text { Technology }\end{array}$ & & & 2 & 1 & \\
\hline
\end{tabular}

Project Number

1.

2.

3.
Project Name

AC Superconducting Power Transmission Cable Development Synthetic Tape Development

Advanced concept Superconducting 10 MVA Generator

Source: Field interview with Eric Forsyth, Brookhaven National Laboratory 
TABLE B.8. Characterization Matrix for Automation/Processing Concepts

\begin{tabular}{|c|c|c|c|c|c|}
\hline $\begin{array}{l}\text { Stage of R\&D } \\
\text { Technology } \\
\text { Application }\end{array}$ & $\begin{array}{l}\text { Basic } \\
\text { Research }\end{array}$ & $\begin{array}{l}\text { Applied } \\
\text { Research }\end{array}$ & $\begin{array}{l}\text { Exploratory } \\
\text { Development }\end{array}$ & $\begin{array}{l}\text { Engineering } \\
\text { Development }\end{array}$ & Demonstration \\
\hline $\begin{array}{l}\text { Scientific } \\
\text { Information/ } \\
\text { Technology Base }\end{array}$ & & & $\begin{array}{ll}7 & 8 \\
1 & \uparrow\end{array}$ & & \\
\hline $\begin{array}{l}\text { Models and } \\
\text { Analytical } \\
\text { Devices }\end{array}$ & 1,2 & 4 & $\begin{array}{ll}\downarrow & \vee \\
7 & 8 \\
3 & \end{array}$ & & \\
\hline $\begin{array}{l}\text { New } \\
\text { Technology }\end{array}$ & & $5,6,9$ & $\frac{V}{3}$ & & \\
\hline
\end{tabular}

Project Number

1.

2.

3.

4.

5.

6.

7.

8.

9.
Project Name

Disturbance Recognition \& System Impact Evaluation ( $U$ of $C$ )

Disturbance Recognition \& System Impact Evaluation (TA:3C) A New Method for Simulating Static Energy Conversion and Control Systems

Laboratory Development and Power System Optimization Research Program

Communications and Control for Electric Power Systems

Advanced Converter Technologies

Athens Automation and Controt Experiment

Athens Utility Board Activities

Switching Transient and Harmonics Study

Source: Field interview with Steve Purucker, Oak Ridge National Laboratory. 
TABLE B.9. Characterization Matrix for BEST/Load Leveling

\begin{tabular}{|c|c|c|c|c|c|}
\hline $\begin{array}{l}\text { Stage of R\&D } \\
\text { Technology } \\
\text { Application }\end{array}$ & $\begin{array}{l}\text { Basic } \\
\text { Research }\end{array}$ & $\begin{array}{l}\text { Applied } \\
\text { Research }\end{array}$ & $\begin{array}{l}\text { Exploratory } \\
\text { Development }\end{array}$ & $\begin{array}{l}\text { Engineering } \\
\text { Development }\end{array}$ & Demonstration \\
\hline $\begin{array}{l}\text { Scientific } \\
\text { Information/ } \\
\text { Technology Base }\end{array}$ & & 2 & & & \\
\hline $\begin{array}{l}\text { Models and } \\
\text { Analytical } \\
\text { Devices }\end{array}$ & & & & & \\
\hline $\begin{array}{l}\text { New } \\
\text { Technology }\end{array}$ & & 1 & & 3 & \\
\hline
\end{tabular}

Project Number

1.

2.

3.
Project Name

Battery Energy Storage Test Facility

Technical and Economical Assessment of Electrochemical Energy Storage Systems

Zinc-Chloride BEST Battery

Source: Field interview with Al Pivec, BEST Facility Program Manager. 
IABLE B.10. Characterization Matrix of Hawaji Deep Water Cable

\begin{tabular}{|l|l|l|l|l|l|}
\hline $\begin{array}{c}\text { Stage of R\&D } \\
\text { Technology } \\
\text { Application }\end{array}$ & $\begin{array}{l}\text { Basic } \\
\text { Research }\end{array}$ & $\begin{array}{l}\text { Applted } \\
\text { Research }\end{array}$ & $\begin{array}{c}\text { Exploratory } \\
\text { Development }\end{array}$ & $\begin{array}{l}\text { Engineering } \\
\text { Development }\end{array}$ & Demonstration \\
\hline $\begin{array}{l}\text { Scientific } \\
\text { Inforriation/ } \\
\text { Technology Base }\end{array}$ & & 1 & & \\
\hline $\begin{array}{l}\text { Models and } \\
\text { Analytical } \\
\text { Devices }\end{array}$ & 2 & 1 & & \\
\hline $\begin{array}{l}\text { New } \\
\text { Technology }\end{array}$ & & & 1 & & \\
\hline
\end{tabular}

Project Number

1.

2.
Project Name

HDWC Program (Phase II)

HDWC Technical Support

Source: Field interview with Charles Traugh, VSE, Inc. 
APPENDIX C

OJESTIONNAIRE USED IN GATHERING INFORMATION ON

TECHNOLOGY TRANSFER ACTIVITIES OF DOE/EES PROGRAM 


\section{Questionnaire for EES Program Managers}

1. Please list any journals or magazines that you or anyone else associated with DOE/EES funded research in failure mechaniams have published in since December 1983, the date of the publication, the title of the article, and the authors of the article. You do not need to include any DOE reports in this listing.

\section{Jounal or Magazine Name}

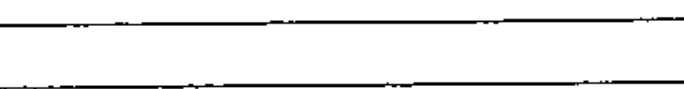

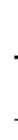

$-$

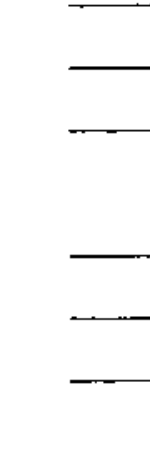

\section{Publication} Date
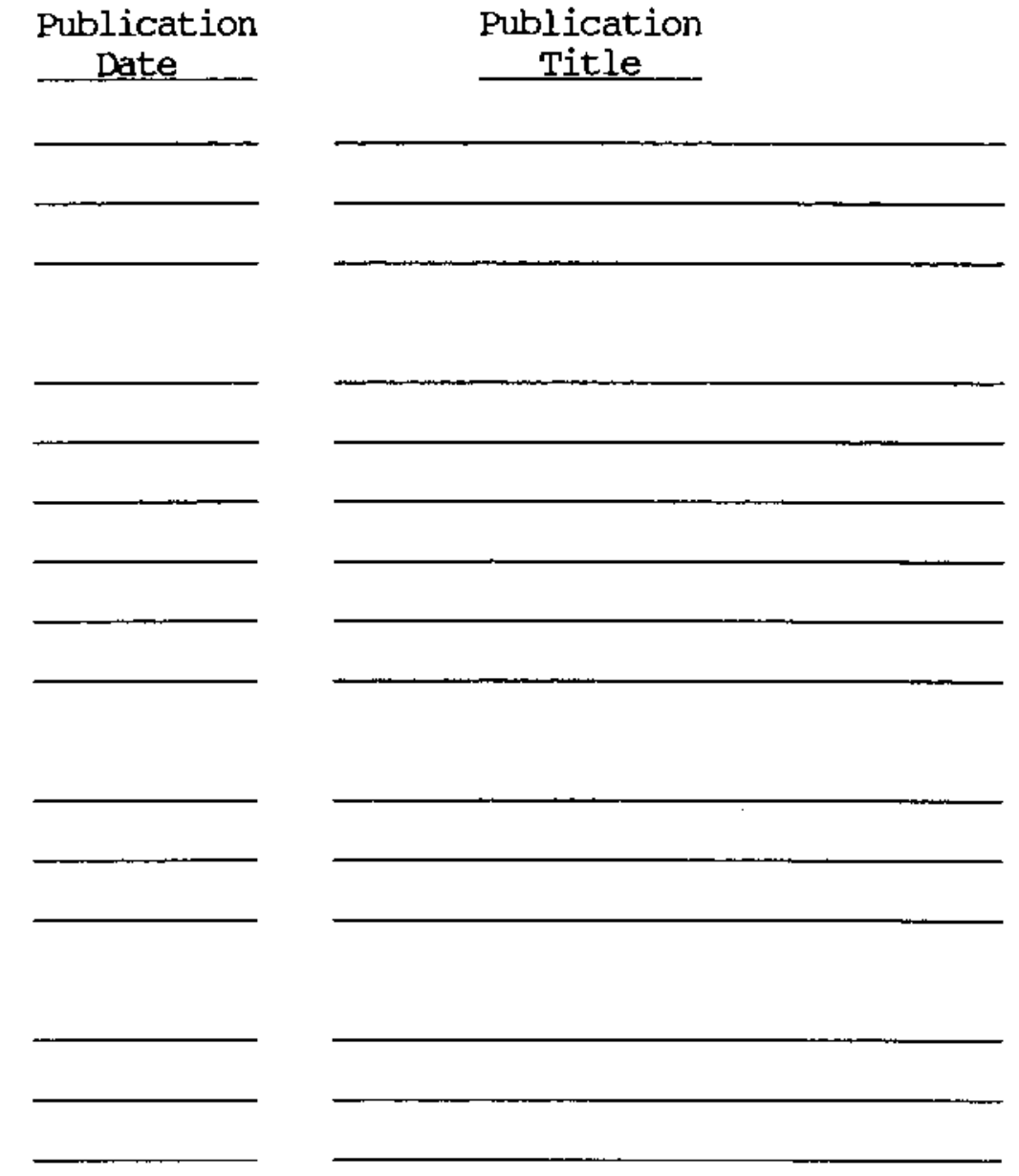

Publication

Title
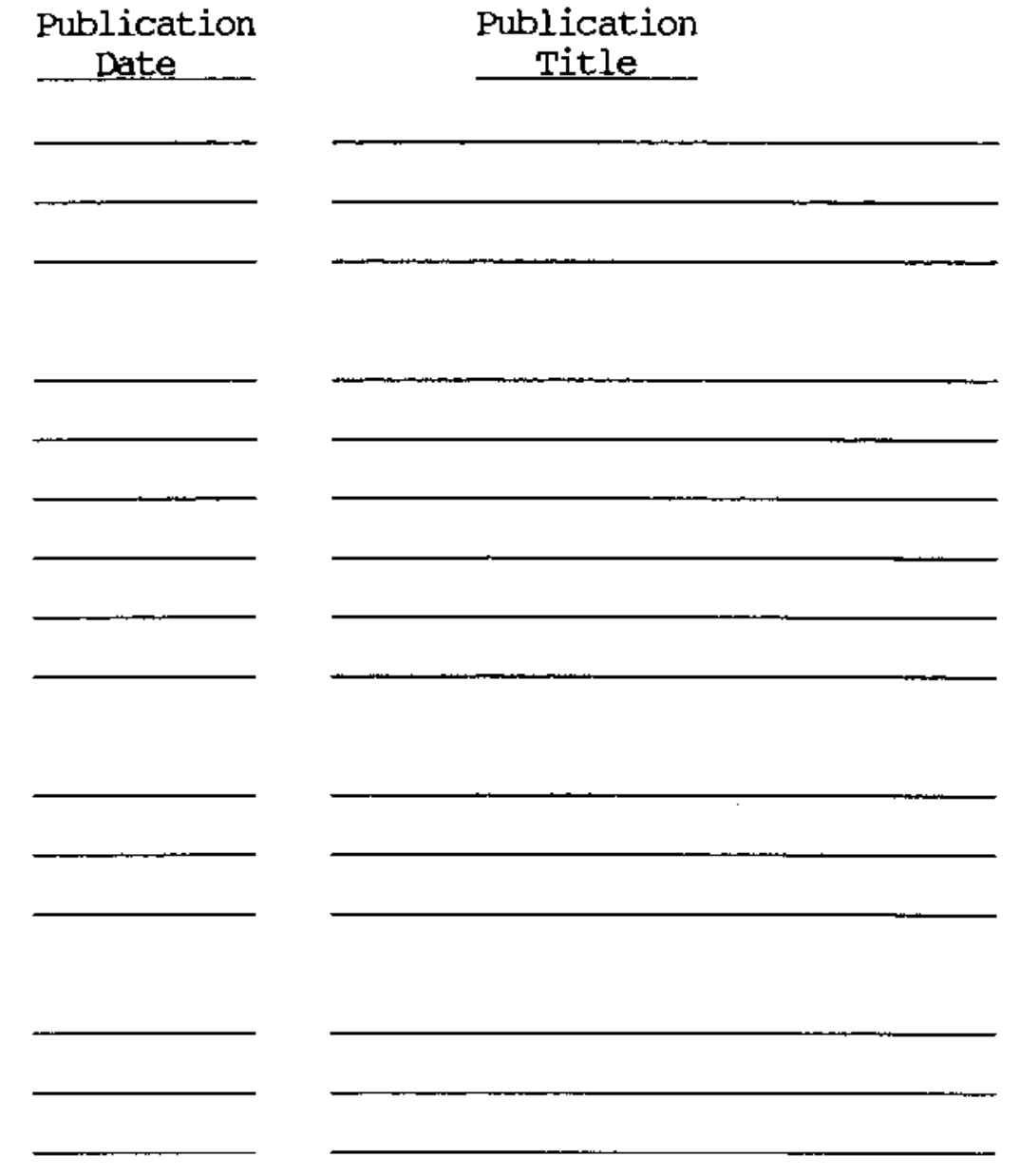


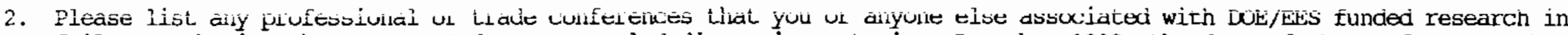
failure mechanisms have presented papers or led discussions at since Decenber 1983, the date of the conference, the title of the paper or discussion group, and the names of the presenters.

\section{Conference Name and sponsor}
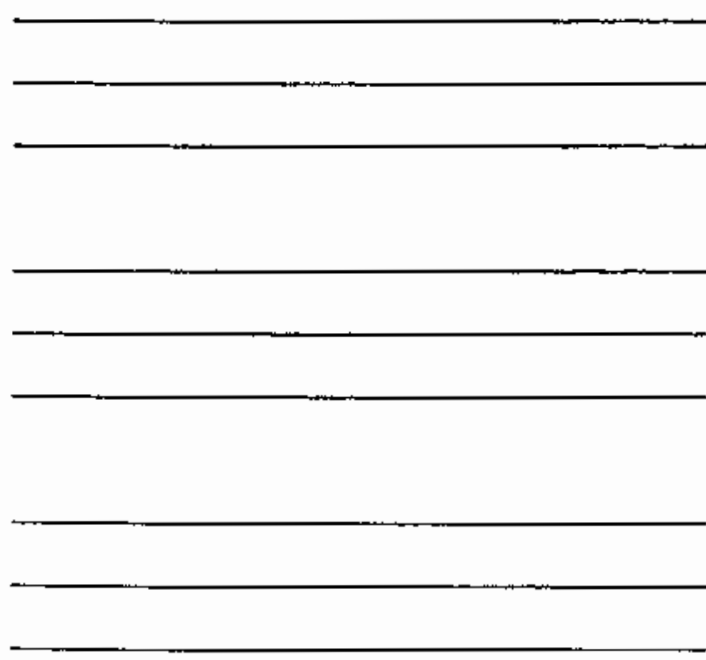

Conference Dates
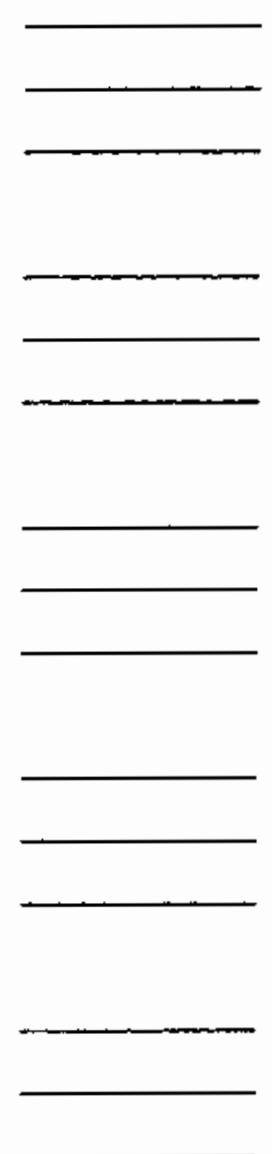

Paper or Discussion Group Title
Names of presenters
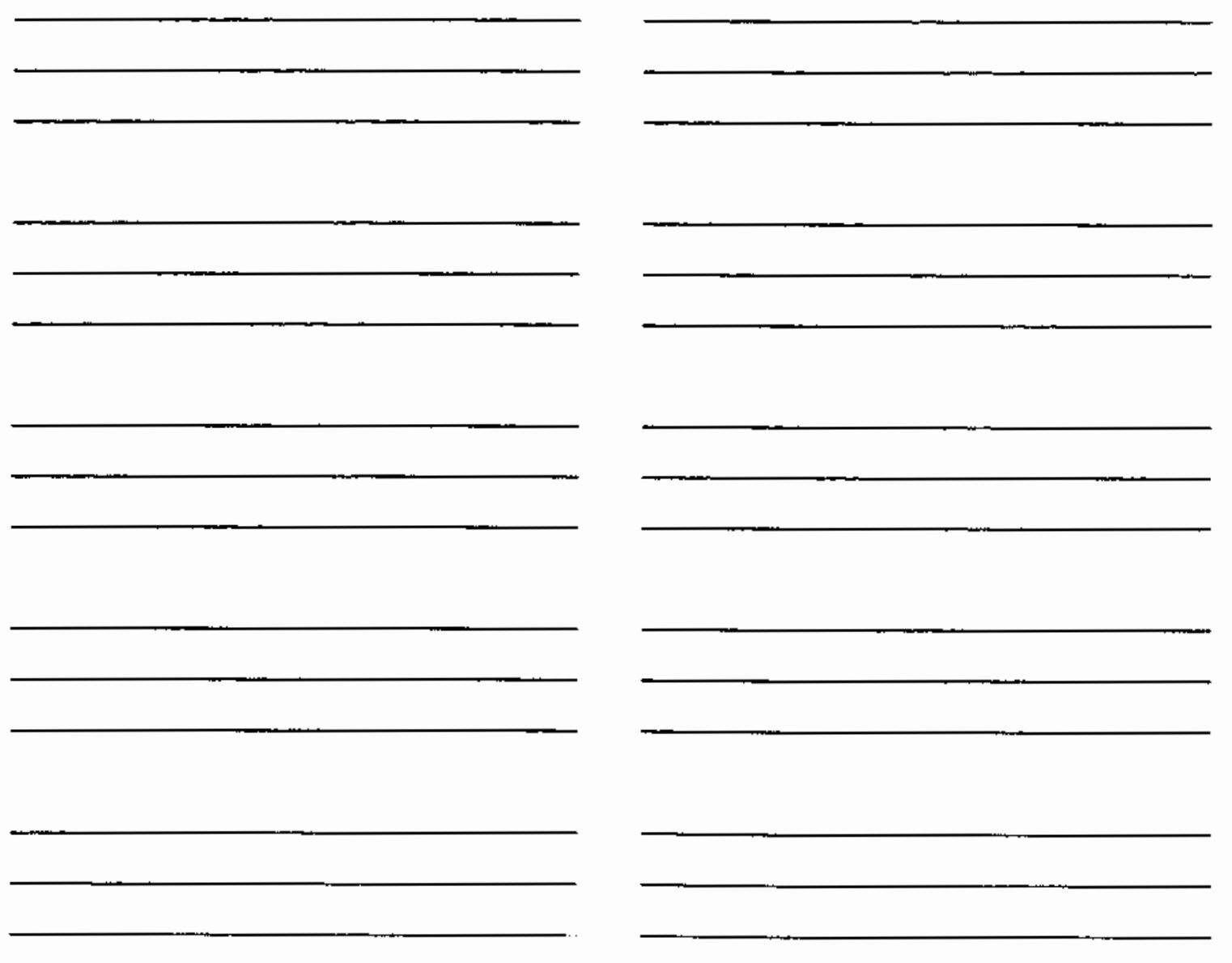
3. Please list any conferences (other than those listed in Question 2) that you or others associated with DoE/EES research i failure mechanisms have attended since December 1983, where there were significant opportunities for you to interact with scientific peers, representatives of government agencies and/or representatives of the utility industry concerning the progress and results of fajlure mechanisms research.

Conference Name

$?$

$\omega$

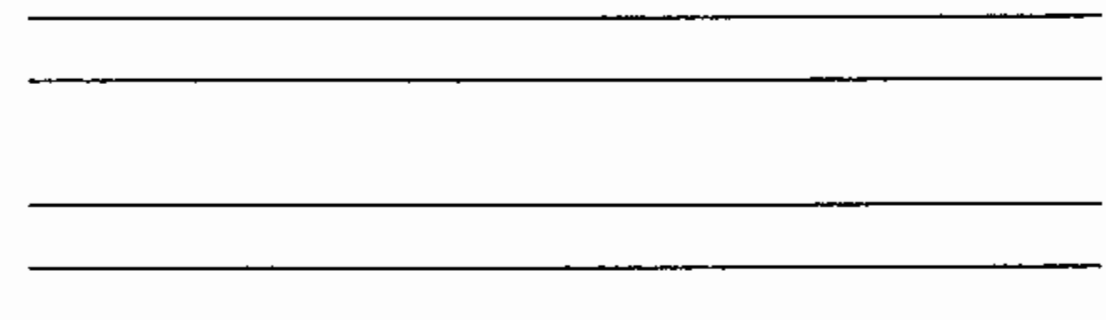

Conference_Dates

Conference Sponsors 
4. Please describe any activities other than publications and conferences that you or others associated with DOE/EES research in failure mechanisms have participated since December 1983 that involve transferring the progress and/or results of this research to target audiences in government agencies, utilities, etc. A list of posstble activities has been provided. If you or others in your research area have performed a listed activity, simply circle the activity and provide additional details on the activity in the space provided.

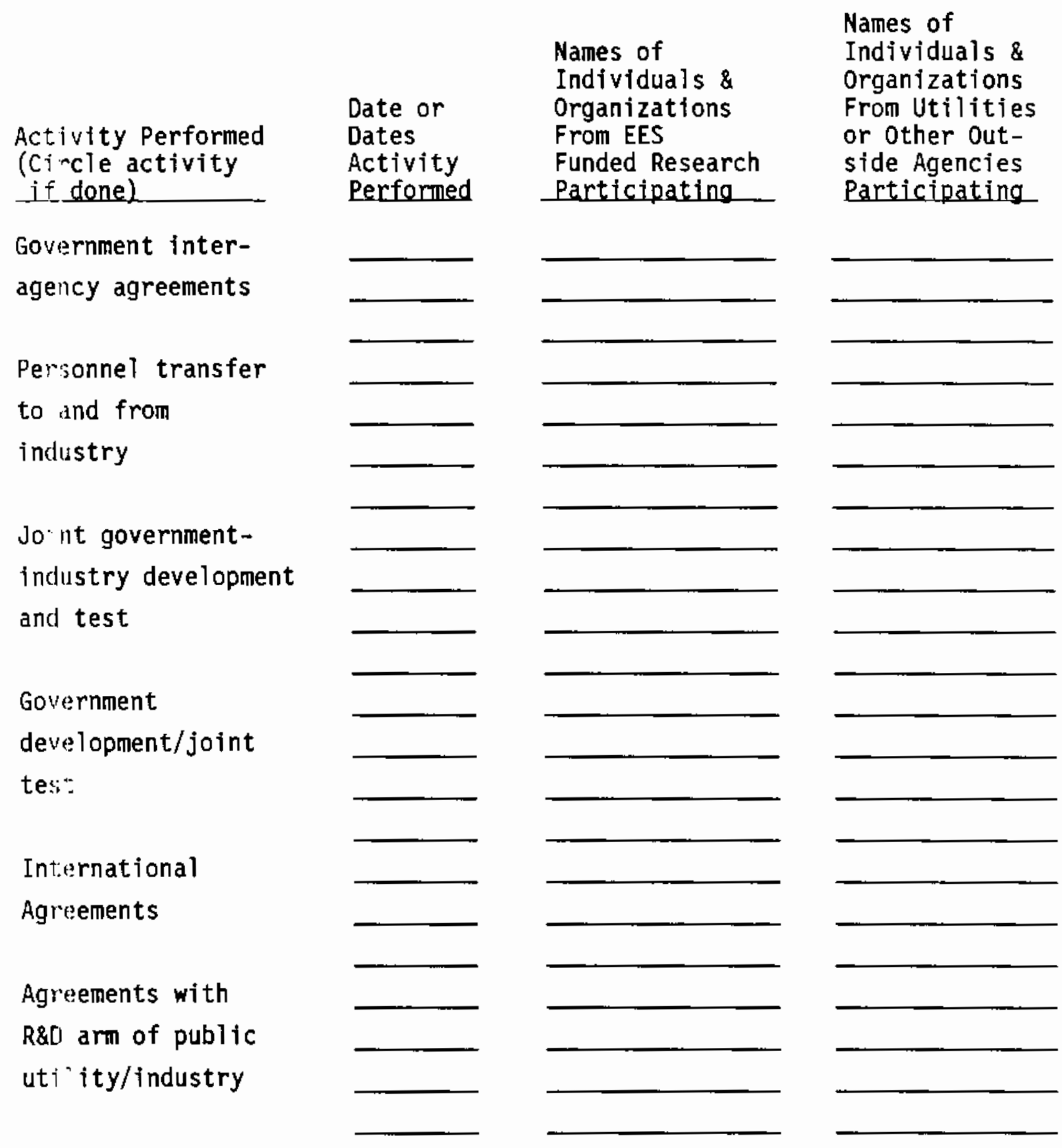

C. 4 
4. (continued)

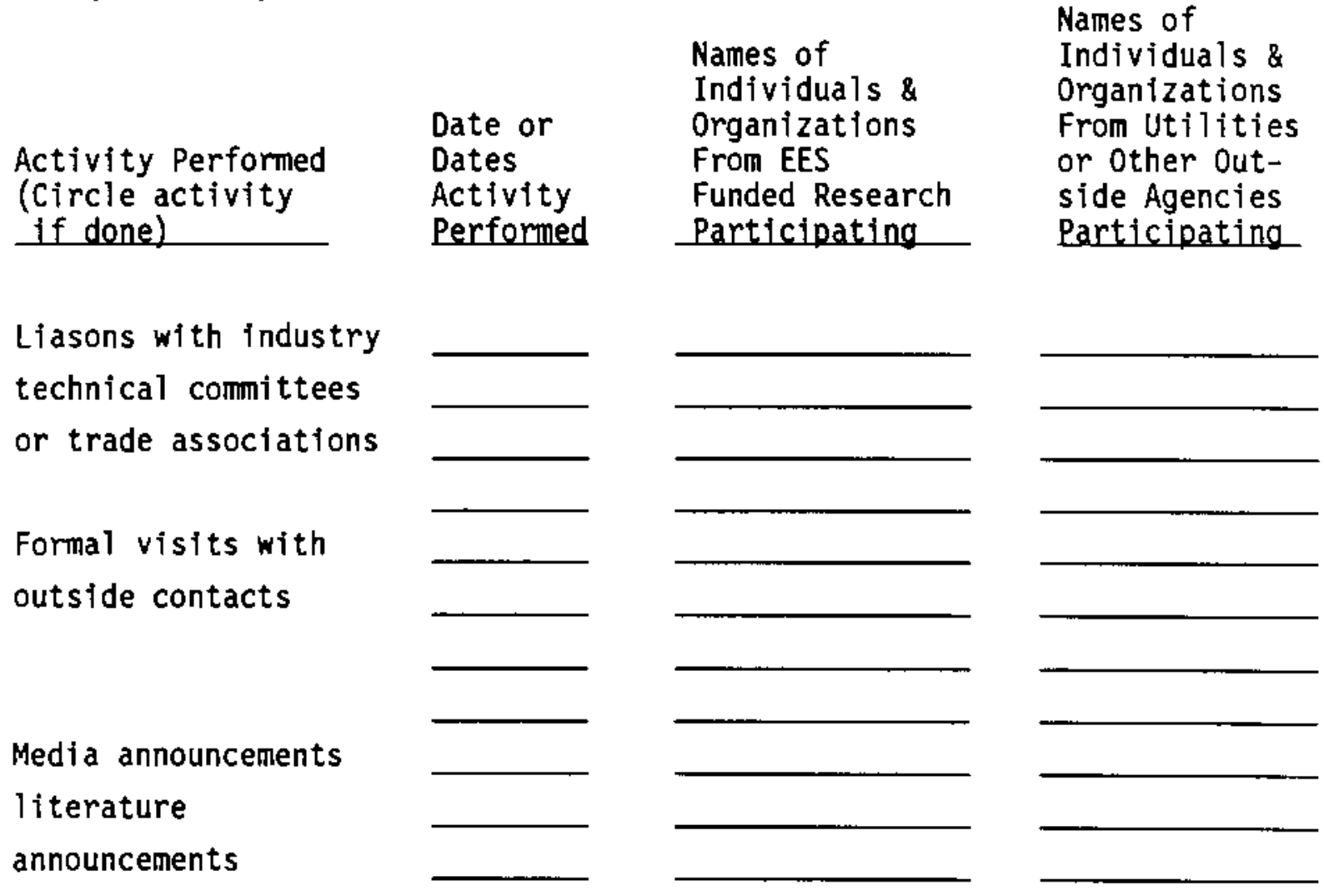

5. Please describe any other technology transfer activities that you or others associated with failure mechanisms research have been involved with. Include the nature of the activity, the dates performed, who participated from the failure mechanisms program, who participated from utilities or other outside agencies, and whether you consider it to have been a successful effort to transfer fallure mechanisms research. 
6. Please identify the audiences that you feel are appropriate for technology transfer efforts related to failure mechanisms research. If an audience is appropriate, simply circle yes and identify two methods that you feel would be effective in transferring technology to this audience. Identified methods for effective technology transfer can be selected from among the following alternatives: 1) magazine or journal articles, 2) presentations at specific conferences, and 3) any of the methods listed in Questions 4 and 5. Space is also provided for you to list any other audiences that may be appropriate for technology transfer for failure mechanisms and the two technology transfer methods you would recommend for these audiences.

Name of Audience
Tentatively
Selected
For Technology
Iraysfer

Utility Engineers

Utility Managers

Transmission and Distribution Equipment Manufacturers

Public Utility

Commissions

Pubi ic Utility Coninissions

EPF:

Yes

Is This Audience Appropriate for Technology

Transfer (Please circle one)
If appropriate, please identify two methods that you would recommend to transfer technology to this audience

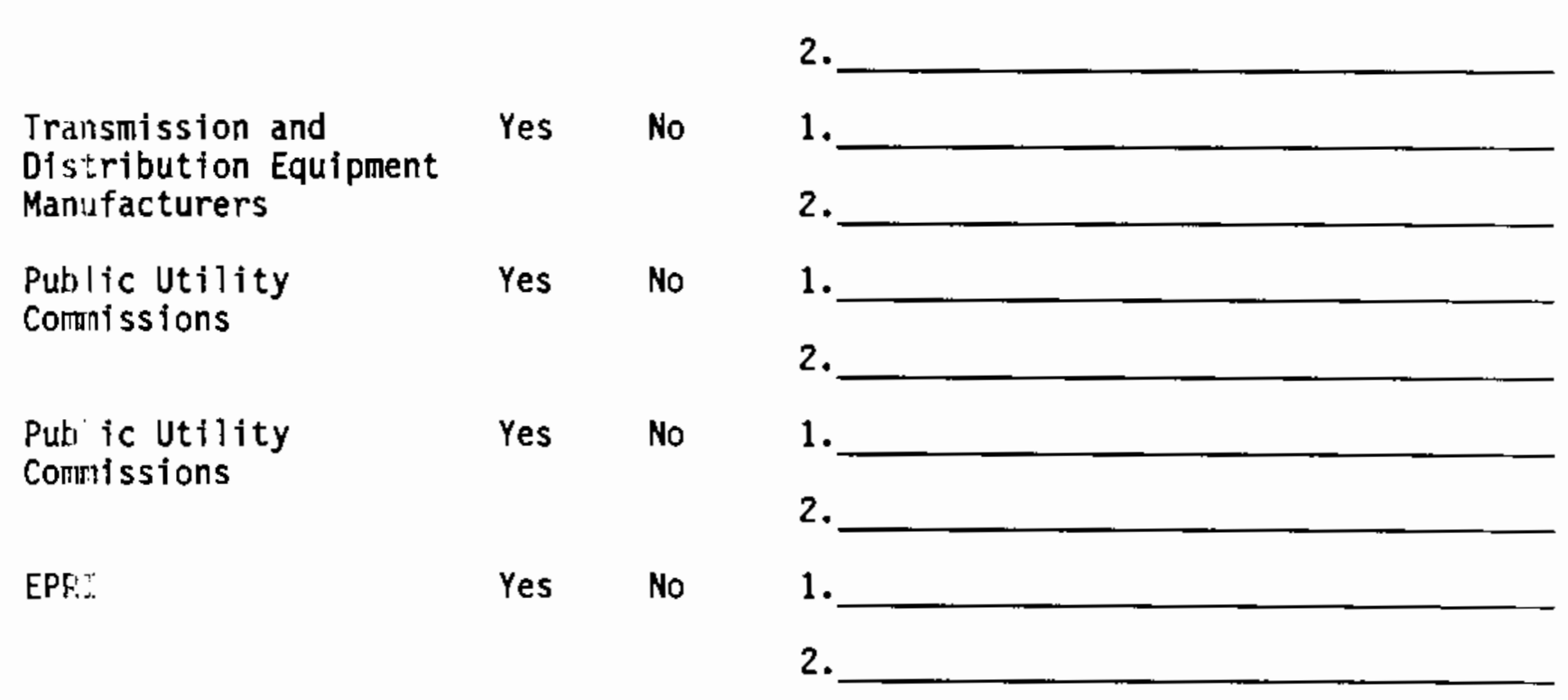

otrer (describe)

1.

2.

other (describe)

1.

2. 
7. Please evaluate the following six factors in terms of their importance in inhibiting technology transfer activities for failure mechanisms research by placing the number corresponding to each factor on the scale that has been provided. For example, if you feel that Factor 6 listed below is "Very Important" and is also the most important of all of the six factors, then a 6 should be placed on the far right-hand side of the scale.

\begin{tabular}{|l|l|l|l|}
\hline $\begin{array}{l}\text { Not at all } \\
\text { Important }\end{array}$ & $\begin{array}{l}\text { Somewhat } \\
\text { Important }\end{array}$ & Important & $\begin{array}{l}\text { Very } \\
\text { Important }\end{array}$ \\
\hline
\end{tabular}

Factor 1: "Don't have enough funding to perform technology transfer."

Factor 2: "Don't have enough time to perform technology transfer."

Factor 3: "Don't know who appropriate audiences are for technology transfer."

Factor 4: "Don't know what technology transfer activities are appropriate and would be effective."

Factor 5: "Other government agencies and industry not interested in our research."

Factor 6: "Research results not ready for technology transfer."

8. Please attach a copy of a current distribution list for a recent final DOE report related to EES fallure mechanisms research.

9. Please provide any comments that you might wish to make on how the process of transferring information and technology developed as part of DOE/EES fallure mechanisms research could be improved. 
10. One of the tasks that is necessary to develop an efficient and successful technology transfer plan is to characterize DOE/EES research in terms of the applications and stages of development of the various technologies that are being developed as part of this research. For performing this task, we have developed a matrix characterization scheme as follows:

\begin{tabular}{|l|l|l|l|l|l|}
\hline \multicolumn{1}{|c|}{$\begin{array}{c}\text { Stage of R\&D } \\
\text { Technology } \\
\text { Application }\end{array}$} & $\begin{array}{l}\text { Basic } \\
\text { Research }\end{array}$ & $\begin{array}{l}\text { Applied } \\
\text { Research }\end{array}$ & $\begin{array}{l}\text { Exploratory } \\
\text { Development }\end{array}$ & $\begin{array}{l}\text { Engineering } \\
\text { Development }\end{array}$ & Demonstration \\
\hline $\begin{array}{l}\text { Information } \\
\text { and/or Data } \\
\text { Generation }\end{array}$ & & & & & \\
\hline $\begin{array}{l}\text { Tools or } \\
\text { Model } \\
\text { (Analytical } \\
\text { Devices) }\end{array}$ & & & & & \\
\hline $\begin{array}{l}\text { Hardware } \\
\text { (New } \\
\text { Technology) }\end{array}$ & & & & & \\
\hline
\end{tabular}

Tease place the projects within your area in the location that you fee? they fall within this matrix. 
APPENDIX D

DOE/EES PROGRAM MAJOR PUBLICATIONS AND CONFERENCE PRESENTATIONS IN 1984-1985 
TABLE D.1. External Publications and Conference Presentations Related To DOE/EES Electric Field Effects Research in 1984-1985

EXTERNAL PUBLICATIONS

Abu-Assal, M. L., et al. 1984. "Effects of Extracellular Electric Fields on Penicillin-Treated Hippocampal Slices." Soc. Neurosci. 10:548 (Abstract).

Adey, W. R. 1984. "Nonlinear, Nonequilibrium Aspects of Electromagnetic Field Interactions at Cell Membranes." In NonT inear Electrodynamics of Biological Systems, eds. W. R. Adey and A. F. Lawrence, Pp. 3-22. PTenum, New York.

Adey, W. R. 1985. "Electromagnetic Field Interactions in the Brain." In Dynamics of Sensory and Cognitive Processing of the Brain, ed. E. Basar, Springer, Heidelberg, Germany.

Adey, W. R. (In Press.) "Nerve Cell Membranes and Intercellular Communication in Brain Tissue." The Fourth Abbie Memorial Lecture. University of Adelaide, August, Australia.

Adey, W. R. (In Press.) "Our Lives in an Electromagnetic Ocean; Fields without and Within." The Sciences. New York Academy of Sciences.

Adey, W. R. 1985. "The Cellular Microenvironment and Signaling Through Cell Membranes." In Electromagnetic Waves and Neurobehavioral Function, eds. R. H. Lovely and M. E. OTConnor. Liss, New York.

Adey, W. R. (In Press.) "The Sequence and Energetics of Cell Membrane Transducive Coupling to Intracellular Enzyme Systems." In Biolelectrochem. Bioenergetics.

Adey, W. R. 1985. "Tissue Interactions with Electromagnetic Fields." In Magnetic Resonance Imaging of the Brain, Head and Neck; a Text Atlas, eds. W. G. Bradley, A. Hasso and W. R. Adey, Pp. 17-25. Aspen, Rockville, Maryland.

Adey, W. R., and A. F. Lawrence, eds. 1984. Nonlinear Electrodynamics of Biological Systems. Plenum, New York.

Aldrich, T. E., and C. E. Easterly, 1985. Handbook of Epidemiological Methods with Special Emphas is on Extremely Low-Frequency Electromagnetic Fields. ORNL-6237, Oak Ridge National Laboratory, Oak Ridge, Tennessee.

Anderson, L. E. 1985. "Interaction of ELF Electric and Magnetic Fields with Neural and Neuroendocrine Systems: An Overview." Biological and Human Health Effects of Extremely Low Frequency Electromagnetic Fields (AIBS).

Anderson, L. E., et al. 19--. "Neuroendocrine Responses in Rats Exposed to 60-Hz Electric Fields." In Interaction of Biological Systems with Static and ELF Electric and Magnetic Fields (Symposium). 
Anderson, L. E., and W. T. Kaune. (In Press.) "Electric and Magnetic Fields a: Extremely Low Frequencies: Interactions with Biological Systems." Nononizing Radiation Protection (WHO).

Anderson, L. E., and R. D. Phillips. (In Press.) "Biological Effects of Electric Fields: An Overview." In Biological Effects and Dosimetry of Nononizing Radiation: Static and ELF Electromagnetic Fields.

Anderson, L. E., and R. D. Phillips. (In Press.) "Dosimetry and Extremely Low Frequency Electric Fields." In Biological Effects and Dosimetry of Non:onizing Radiation: Static and ELF Electromagnetic Fields (Symposium).

Bawin, S. M., et al. 1984. "Influences of Sinusoidal Electric Fields on Eccitability in the Rat Hippocampal Slice." Brain Research. 323:227-237.

Bawin, S. M., et al. 1985. "Comparison Between the Effects of Extracellular Direct and Sinusoidal Currents on Excitability in Hippocampal Slices." Brain Research. 362:350-354.

Bawin, S. M., et al. 1985. "Effects of Extracellular Fields on Normal and Epileptiform Activity in Adult and Immature Rat Hippocampal Slices." Soc. Neurosci. 11:492 (Abstract).

Bradley, W. G., A. N. Hasso and W. R. Adey, eds. 1985. Magnetic Resonance Inaging of the Brain, Head and Neck. Aspen, Rockville, Maryland.

Byu's, C. V., et al. 1984. "Alterations in Protein Kinase Activity Following Exposure of Cultured Human Lymphocytes to Modulated Microwave Fields." Bioelectromagnetics. 5:341-351.

Cail, C. D., and R. A. Luben. 1985. "Pulsed Electromagnetic Field Effects on "TH-Stimulated CAMP Accumulation and Bone Resorption in Mouse Calvaria." In roceedings of the 23rd Hanford Life Sciences Symposium.

Cain, C. D., and R. A. Luben. (In Press.) "Pulsed Electromagnetic Field Modifies CAMP Metabolism and Ornithine Decarboxylase activity in Primary Bone Sells." In International Conference on Electric and Magnetic Fields in Medizine and Biology London: 4-5 DeC. 1985.

Caranaugh, H. April 1985. "CIGRE Report Says EHV Fields are Safe." Electrical Norld. Pp. 87-88.

Cory, W. E., and W. R. Rogers. 1984. "Operating Characteristics of the CRIEPI/DOE Nonhuman Primate, High Voltage, $60 \mathrm{~Hz}$ Exposure Facility." In Interaction of Biological Systems with Static and ELF Electric and Magnetic Fields, 23 rd Hanford Life Sciences Symposium. Richland, washington.

Creim, J. A., et a1. (In Press.) "Exposure to 30 Gauss Magnetic Fields Does Yot Cause Avoidance Behavior in Rats." In Interaction of Biological Systems with Static and ELF Electric and Magnetic Fields (Symposium). 
Creim, J. A., et al. 1984. "Attempts to Produce Taste-Aversion Learning in Rats Exposed to 60-Hz Electric Fields." Bioelectromagnetics. 5:271-282.

Devine, M. T. April 1985. "The Fears of High Voltage Transmission Lines." Electrical World. pp. 7-9.

Easterly, C. E., et al. (In Progress.) A Preliminary Examination of the Data Base for Estimating Human Health Effects from 60-Hz High Voltage Transmission Lines. ORNL/TM, Oak Ridge National Laboratory, Oak Ridge, Tennessee. In progress.

Easterly, C. E., et al. 1984. "ELF Bioeffects: Use of a Negative Data in a Structured Argument." In Proceedings of the Twenty-Third Hanford Life Science Symposium. Richland, Washington.

Ehret, C. F., et al. (In Press.) Action of High Strength $60 \mathrm{~Hz}$ Elactric Field on Circadian Rhythms in Small Rodents in Electromagnetic Waves and Neurobehavioral Function. R. H. Lovely and M. E. O'Conner, eds. Allen R. Liss, New York.

Forslund, F. April 1984. "Tales of Power." Pacific Northwest. pp. 95-98.

Frazier, M. E., J. E. Samuel and W. T. Kaune. (In Press.) "Viabilities and Mutation Frequencies of CH0-K1 Cells Following Exposure to 60-Hz Electric Fields." In Interaction of Biological Systems with Static and ELF Electric and Magnetic Fields (Symposium).

Gibson, E. G. 1984. "Nonhuman Primate Behavioral Toxicology: Effects of a $60 \mathrm{~Hz}$ Electric Field on Baboons." Am. J. Anthropol. 63:162 (Abstract).

Groh, K. R., et al. (In Press.) "Multiparameter Data Acquisition System for Studies of Circadian Rhythms." In Proceedings of the NATO Advanced Research Workshop on Chronobiotechnology and Chronobiological Engineering, eds. L. E. Scahering, C. F. Ehret and S. Hallberg. Sijthoff and Noordhoff, Ansterdam.

Jaffe, R. A., et al. 1983. "Perinatal Exposure to a 60-Hz Electric Field: Effects on the Development of the Visual-Evoked Response in the Rat." Bioelectromagnetics. $4: 327-340$.

Kaune, W. T. 1985. "Coupling of Living Organisms to ELF Electric and Magnetic Fields." Biologocal and Human Health Effects of Extremely Low Frequency Electromagnetic Fields (AIBS).

Kaune, H. T., L. M. Kistler and M. C. Miller. (In Press.) "Comparison of the Coupling of Grounded and Ungrounded Humans to Vertical 60-Hz Electric Fields." In Interaction of Biological Systems with Static and ELF Electric and Magnetic Fields (Symposium).

Kaune, W. T., et a1. 1984. "System for the Exposure of Cell Suspensions to Power Frequency Electric Fields." Bioelectromagnetics. 5:117-129. 
Kaune, W. T., and F. A. McCreary. 1985. "Numerical Calculations and Measurements of $60-\mathrm{Hz}$ Current Densities Induced in an Upright Grounded Cylinder." Bioelectromagnetics. $6: 209-220$.

Kaune, W. T., and M. C. Miller. 1984. "Short-Circuit Currents, Surface Electric Fields, and Axial Current Densities for Guinea Pigs Exposed to ELF Elec.. tric Fields." Bioelectromagnetics. 5:361-364.

Kaune, W. T., and W. C. Forsythe. 1985. "Current Densities Measured in Human Models Exposed to 60-Hz Electric Fields." Bioelectromagnetics. 6:13-23.

Kelman, B. J., R. L. Rommereim and D. D. Mahl um. (In Press.) "Effects of Static Homogenous and Gradient Magnetic Fields on Mice During Lifetime Exposure." In Interaction of Biological Systems with Static and ELF Electric and Magnetic Fields (Symposium).

Klien, K. August 1984. "High Voltage Fields: Dangerous to Living Tissues?" Agricultural Engineering. Pp. 18-20.

Lee, Jr., J. December 1984. "High Voltage Transmission Lines: The Ongoing Search for 8iological Effects." Public Utilities Fortnightly. pp. 33-42.

Lin-Liu, S., C. Cain and W. R. Adey. 1984. "Effects of ElF on Forskolin Activation of Adenylate Cyclase in Hipocampal Slices." In Proceedings of the 6tin Annual Meeting of the Bioelectromagnetics Socjety, p. 5. At Tanta, Georgia.

Lin-Liu, S., W. R. Adey and M. M. Poo. 1984. "Migration of Cell Surface Concanavalin A Receptors in Pulsed Electric Fields." Biophys. J. 45:1211-1218.

Lovely, R. H. (In Press.) "Studies Assessing the Behavioral Toxicology of Electric Fields." In Electromagnetic Waves and Neurobehavioral Function: An International Workshop.

Lovely, R. H. 1985. "Behavioral Toxicology in ELF Electric and Magnetic Fields." Assessments and Viewpoints on the Biological and Human Health Effects of Extremely Low frequency (ELF) Electromagnetic Fields (AIBS).

Lovely, R. H., and R. D. Phillips. (In Press.) "Perceptions and Avoidance of 60-Hz Electric Fields in Rats: Summary of Effects and Key Parameters." In Interaction of Biological Systems with Static and ELF Electric and Magnetic Fields (Symposium).

Luben, R. A, and C. D. Cain. 1984. "Use of Bone Cell Hormone Response Systems to Investigate Bioelectromagnetic Effects on Membranes in Vitro." In Nonlinear Electrodynamics of Biological Systems, eds. W. R. Adey and A. F. Lawrence, p. 23. Plenum Press, New York. 
Lucas, J. H., and M. J. Johnson. 1984. "In Vitro Simulation of the Electromagnetic Fields near a 3-Phase Powerline." Paper presented at the IEEE Symposium on Electromagnetic Compatibility, May 1983, San Antonio, Texas. Also available as IEEE CH2035-4/84/000-0157 1984.

Lyle, D. B., G. W. Kamin and W. R. Adey. 1984. "Combined Effects of a $60 \mathrm{~Hz}$ Pulsed 20 Gauss Magnetic Field and 12-0-Tetradecanoylphorbol-Acetate (TPA) on T-Cell Growth Factor Responsiveness and Human Myeloid Leukemia Proliferation." In Proceedings of the 6th Annual Meeting of the Bioelectromagnetics Society, p. 8, AtTanta, Georgia.

Mcknight, R. H. April 1985. "The Measurement of Net Space Density Using Air Filtration Methods." IEEE Trans. on Power Appar. and Syst. PAS-104:971-976.

Misakian, M. February 1983. Discussion of paper "Anaylsis of Calibration Arrangements for AC Field Strength Meters," by T. Takuma, et al. IEEE Trans. Power Appar. and Syst. PAS-104:489-496.

Misakian, M. 1984. "Calibration of Flat 60-Hz Electric Field Probes." Bioelectromagnetics. 5:447-450.

Misakian, M., and P. M. Fulcomer. December 1983. "Measurement of Nonuniform Power Frequency Electric Fields." IEEE Trans. on Elecr. InsuT. $E I-18(6): 657-661$.

Morgan, M. G., K. Florig, I. Nair and D. Lincoln. February 1985. "Power-Line Fields and Human Health." IEEE Spectrum. pp. 62-68.

Phillips, R. D. (In Press.) "Effects of 60-Hz Electric Fields on the Function of the Nervous System." In Electromagnetic Waves and Neurobehavioral Function: An International Workshop.

Rogers, W. R., and W. E. Cory. (In Press.) "Effects of $60 \mathrm{~Hz}$ Electric Fields of 30 and $60 \mathrm{kV} / \mathrm{m}$ (unperturbed field strength) on Operant and Social Behavior of Nonhuman Primates." In Interaction of Biological Systems with Static and ELF Electric and Magnetic Fields, 23rd Hanford Life Sciences Symposium. Richland, Washington.

Sagan, P. M. 1985. "Threshold Effect: Limits of Behavioral Assessment of Microwave Detection." In Behavioral Effects of Microwave Radiation Absorption, eds. J. C. Monahan and J. A. D'Andrea, pp. 9-21. Publication No. FDA 85-8238. U.S. Department of Health and Human Services.

Sagan, P. M., et al. 1982. "Study of Biological Effects of EM Fields." In Proceedings of the U.S.-U.S.S.R. Workshop on kervous System Effects of Electromagnetic Waves, 1984. National Institute of Environmental Health Sciences Research, Triangle Park, North Carolina. 
Sagan, P. M., and M. E. Stell. 1985. "Circadian Variation in the Threshold for Electric Field Detection." (Poster) In Proceedings of the Seventh Annual Meeting of the Bioelectromagnetics Society, $\mathrm{p} .57$. San Francisco, California (Abstract $\mathrm{J}-30)$.

Sagan, P. M., and M. E. Stell. 1985. "How Rats Detect $60 \mathrm{~Hz}$ Electric Fields." In Proceedings of the Seventh Annual Meeting of the Bioelectromagnetics Society, P. 21. San Francisco, California (Abstract E-7).

Sheppard, A. R., et a1. 1984. "Modulation of the Firing Rate of Aplysia Neurons by Sinusoidal Electric Fields and Intracellular Currents." Neuroscience Abstracts. 10(2):311.10. Also presented at the Fourteenth Annual Meeting of the Society of Neuroscience, Anaheim, California.

Sheppard, A. R., et al. 1985. "Angular Dependence of Thresholds for Electric Field Effects on Firing Rates of Aplysia Pacemaker Cells." Neuroscience Abstracts. 11(1):506.

Sikov, M. R. 1985. "Reproductive and Developmental Alterations Associated with Exposure of Mammals to ELF Electromagnetic Fields." Assessments and Viewpoints on the 8iological and Human Health Effects of Extremely Low Frequency (LF) Electromagnetic Fields (AIBS).

Sikov, M. R., et al. 1984. "Effects of 60-Hz Electric Fields on Prenatal and Postnatal Development in Rats. Bioelectromagnetics. 5:101-112.

Star, D. 1985. "Mysterious Microwaves: Life." Omni. p. 22.

Vasquez, B. J., P. McNeeley and W. R. Adey, 1984. "Effects of $60 \mathrm{~Hz}$ Electric Fields on Brain Biogenic Amines in the Rat." Neuroscience Abstracts. $10: 682$.

Vasquez, B. J., P. McNeeley and W. R. Adey. 1985. "In Vitro Release of Rat Brain Catecholamines after Exposure to ELF Modulated Fields." In Proceedings of the 6th Annual Meeting of the Bioelectromagnetics Society, p. $8 \overline{2}$. Atlanta, Georgia.

Wilson, 8. W., E. K. Chess and L. E. Anderson. (In Press.) "60-Hz Electric Field Effects on Pineal Melatonin Rhythms: Time Course for Onset and Recovery." Bioelectromagnetics. 7.

Zaffanella, L. E. 1984. "Space Charge Effects of HVDC Transmission Line Corona - Full Scale and Model Line Tests." In Proceedings of the 1984 Japan.. United States Science Seminar on Detection and Controt of Electric Field and Space Charge in Electrical Environmental Problems. Fukuoka, Japan. 
Adey, W. R. 1985. "The Sequence and Energetics of Cell Membrane Transductive Coupling to Intracellutar Enzyme Systems." Paper presented at the DOE, EPRI, NYSHD Contractor's Review, Washington, D.C.

Albert, E. N., and L. E. Anderson. 1985. Morphological Aspects of Developing Cerebellum in 60-Hz Electric Fields." Paper presented at the DOE/EPRI/NYC Contractors Review, November 1985.

Anderson, L. E. 1984. "Biological Effects of Electric and Magnetic Fields: Laboratory Research." Paper presented at the Bonneville Power Administration Workshop, July 1984.

Anderson, L. E. 1984. "Neurochemical Effects of 60-Hz Electric Fields. Paper presanted at the DOE/EPRI/NYS Contractors Review, November 1984.

Anderson, L. E. 1984. "The Pineal Gland and Implications in Electric Field Research." Paper presented at the DOE Contractors Workshop, November 1984.

Anderson, L. E. 1985. "Electric and Magnetic Fields at Extremely Low Frequencies: Interactions with Biological Systems." Paper presented at the World Health Organization (WHO) Working Group Workshop, October 1985.

Anderson, L. E. 1985. "Interaction of ELF Electric and Magnetic Fields with Neural and Neuroendocrine Systems. An Overview Paper." Paper presented at the American Institute of Biological Sciences, February 1985.

Anderson, L. E. 1985. "Interaction of ELF Fields with the Nervous System." Paper presented at the Fifth Workshop of the US/USSR Scientific Exchange Program, April 1985.

Anderson, L. E., et al. 1984. "Neuroendocrine Responses in Rats Exposed to 6D-Hz Electric Fields." Paper presented at the 23rd Annual Hanford Life Sciences Symposium, October 1984.

Barnes, F. S., A. R. Sheppard and M. B. Sagan. 1984. "Phase Locking of Pacemaker Cells from Aplysia with External Electrical Signals." Paper presented at the 6th Annua? Meeting of the Bioelectromagnetics Society, Atlanta, Georgia.

Bawin, S. M., et al. 1985. "Effects of ELF Electric Fields on Normal and Epileptiform Activity in Adult and Immature Rat Hippocampal S1ices." Paper presented at the DOE, EPRI, NYSHD Contractor's Review, Washington, D.C. (Abstract).

Cain, C. D., et al. 1985. "Pulsed Electromagnetic Field Inciuences PTHStimulated CAMP Accumulation and Ornithine Decarboxylase Activity in Primary Bone Cells." Paper presented at the DOE, EPRI, NYSHD Contractor's Review, Washington, D.C. (Abstract). 
Cain, C. D., R. A. Luben and W. R. Adey. 1984. "Pulsed Electromagnetic Field Effects on PTH Stimulated CAMP Accumulation and Bone Resorption in Mouse Calvariae." Paper presented at the DOE, EPRI, NYSHD Contractor's Review, Washington, D.C. (Abstract).

Creim, J. A., et al. 1984. "Rats' Preference for Saccharin-Flavored Chow Depends on Feeder Location in a $60-\mathrm{Hz}$ Electric Field." Paper presented at the Sixth Annual Meeting of the Bioelectromagnetics Society, July 1984.

Creim, J. A., R. H. Lovely and W. T. Kaune. 1984. "Exposure to 30-Gauss Magnetic Fields Does Not Cause Avoidance Behavior in Rats." Paper presented at the 23rd Annual Hanford Life Sciences Symposium, October 1984.

Creim, J. A., et a1. 1985. "60-Hz Magnetic Fields: Do Rats Avoid Exposure?" Paper presented at the Seventh Annual Meeting of the Bioelectromagnetics Society, June 1985.

Fletcher, W. 1985. "The Influence of Weak Electric Fields on the Intercellular Communication of Bioactive Signals." Paper presented at the OOE, EPRI, NYSHD Contractor's Review, Washington, D.C. (Abstract).

Frazier, M. E., et al. 1985. "Cellular and Molecular Models for Measuring Effects of $60-\mathrm{Hz}$ AC Electromagnetic Fields." Paper presented at the DOE/EPRI/NYC Contractors Review, November 1985.

Frazier, M. R., J.E. Samual and W. T. Kaune. 1984. "Viabilities and Mutation Frequencies of $\mathrm{CHO}-\mathrm{K} 1$ Cells Following Exposure to 60-Hz Electric Fields." Paper presented at the 23rd Annual Hanford Life Sciences Symposium, October 1984.

Gnadt, P. A., organizer. 1984. DOE/EPRI Contractors Review of Biological Effects from Electric and Magnetic Fields, November 5-9, St. Louis, Missouri.

Hilton, D. I., and L. E. Anderson. 1984. "Catecholamine and Indolamine Levels in Various Brain Regions of Rats Exposed to 60-Hz Electric Fields." Paper presented at the 14th Annual Meeting of the Society for Neurosciences, October, 1984.

Xamin, G., A. R. Sheppard and R. Jones. 19--. "Development of 100KHz Electric Field Exposure Apparatus for Small Animals." Paper Presented at the Seventh Annual Meeting of the Bioelectromagnetics Society, June 16-20, 19--, San Francisco, California (Abstract).

Kaune, W. T. 1984. "Sources and Structure of Magnetic and Electric Fields in the Home." Paper presented at the 23rd Annual Hanford Life Sciences Symposium, October 1984.

Kaune, W. T. 1985. "Coupling of Living Organisms to ELF Electric and Magnetic Fields. An Overview Paper." Paper presented at the American Institute of Biological Sciences, February 1985. 
Kaune, W. T. 1985. "Dosimetry of Extremely Low Frequency Fields." Paper presented at the Fifth Workshop of the US/USSR Scientific Exchange Program, April 1985.

Kaune, W. T. 1985. "Electric and Magnetic-Field Dosimetry." Paper presented at the DOE/EPRI/NYC Contractors Review, November 1985.

Kaune, W. T. 1985. "Review of Experimental ELF Dosimetry." Paper presented at the ELF Electric Field Dosimetry Workshop, November 1985.

Kaune, W. T., L. M. Kistler and M. C. Miller. 1984. "Comparison of the Coupling of Grounded and Ungrounded Humans to Vertical 60-Hz Electric Fields." Paper presented at the 23rd Annual Hanford Life Sciences Symposium, October 1984.

Kaune, W. T., and F. McCreary. i985. "Numerical Calculations and Measurements of 60-Hz Current Densities Induced in an Upright Grounded Cylinder." Paper presented at the Seventh Annual Meeting of the Bioelectromagnetics Society, June 1985.

Kaune, W. T., and W. C. Forsythe. 1984. "Measurement of the 60-Hz Current Densities Induced in Grounded Models of Rats and Mice." Paper presented at the DOE/EPRI/NYC Contractors Review, November 1984.

Kaune, W. T., and M. C. Miller. 1984. "Comparative Dosimetry for Guinea Pigs Exposed to ELF Electric Fields." Paper presented at the Sixth Annual Meeting of the Bioelectromagnetics Society, July 1984.

Kelman, B. J., R. L. Romereim and D. D. Mahlum. 1984. "Lifetime Exposure of CE-1 Mice to 1-T and 2-T/m Gradient de Magnetic Fields." Paper presented at the Sixth Annual Meeting of the Bioelectromagnetics Society, July 1984.

Kelman, G. J., R. L. Romereim and D. D. Mahlum. 1984. "Effects of Static Homogenous and Gradient Magnetic Fields on Mice During Lifetime Exposure." Paper presented at the 23rd Annual Hanford Life Sciences Symposium, October 1984.

Lessor, D. L. 1985. "Computer Modeling of 60-Hz Electric Field Coupling to Biological Tissue." Paper presented at the DOE/EPRI/NYC Contractors Review, November 1985.

Lessor, D. L. 1985. "Theoretical ELF Dosimetry Modeling." Paper presented at the DOE/EPRI/NYC Contractors Review, November 1985.

Lin-Liu, S., C. Cain and W. R. Adey. 1985. "Effects of ELF on Forskolin Activation of Adenylate Cyclase in Hippocampal Slices." Paper presented at the DOE/EPRI, NYSHD Contractor's Review, Saint Louis, Missouri (Abstract). 
Lovely, R. H. 1984. "Studies Assessing the Behavioral Toxicology of Electric Fields." Paper presented at Electromagnetic Waves and Neurobehavioral Function: An International Workshop, August 1984.

Lovely, R. H. 1984. "Studies in the Behavioral Toxicology of 60-Hz Electric Fields." Paper presented at the DOE/EPRI/NYC Contractors Review, November 1984.

Lovely, R. H., J. A. Creim and L. E. Anderson. 1985. "Studies in the Behavioral Toxicology of 60-Hz Electric Fields." Paper presented at the DOE/EPRI/NYC Contractors Review, November 1985.

Lovely, R. H., J. A. Creim and L. E. Anderson. 1985. "The Role of Ears, Vibrissa, and Other Body Hair in the Rats Aversion to Intense 60-Hz Electric Fields." Paper presented at the Seventh Annual Meeting of the Bioelectromagnetics Society, June 1985.

Lovely, R. H., J. A. Creim and R. D. Phillips. 1984. "Adult Behavioral Effects of Prenatal and Early Postnatal Exposure to 60-Hz Electric Fields in the Rat. Paper presented at the XXI General Assembly of the International Union of Radio Sciences, August 1984.

Lovely, R. H., and R. D. Phillips. 1984. "Perception and Avoidance of 60-Hz Electric Fields in Rats: Summary of Effects and Key Parameters." Paper presented at the 23rd Annual Hanford Life Sciences Symposium, October 1984.

Lyle, D. B., G. W. Kamin and W. R. Adey. 1984. "T-Cell Growth FActor Responsiveness/Production and 3 -Thymidine Incorporation By Myeloid Leukemia Cells in the Presence of a $60 \mathrm{~Hz}$ Pulsed 20 Gauss Magnetic Field and/or 12-0-Tetradecanoy?phorbol-13-Acetate (TPA)" Department of Energy Contractors Review, November 5-9, St. Louis, Missouri (Abstract).

Lyle, O. B., et a1. 1985. "T-Cell Growth Factor Production and ${ }^{3} \mathrm{H}$-Thymidine Incorporation by the Myeloid Leukemia Cells M1 and U-937 in the Presence of 12-0-Tetradecanoylphorbol-13-Acetate (TPA) are Unaffected by a $60 \mathrm{~Hz}$ Puised 20 Gauss Magnetic Field." Paper presented at the Seventh Annual Meeting of the Bioelectromagnetics Society, June 16-20, 1985, San Francisco, California (Abstract).

Lyle, D. B., et al. 1984. "Response of Cytoxic Lymphocytes to Specific Growth Factor, Allogeneic Cytotoxicity, and Proliferation of Myeloid Leukemia Cell Lines in the Presence of ELF Fields". Paper presented at the Department of Energy Contractors Review, November 5-7, 1985, Alexandria, Virginia (Abstract).

McClanahan, B. J. 1984. "Evaluation of the Mutagenic Potential of a $60-\mathrm{Hz}$ Electric Field on Germ Cells of Male Mice." Paper presented at the DOE/EPRI/NYC Contractors Review, November 1984. 
Morris, J. E. 1984. "Immunological Studies and 60-Hz Electric Fields." Paper presented at the DOE/EPRI/NYC Contractors Review, November 1984.

Morris, J. E. 1985. "Immune System Responses in 60-Hz Electric Fields. Paper presented at the Seventh Annual Meeting of the Bioelectromagnetics Society, June 1985.

Morris, J. E. 1985. "Immunological Studies and 60-Hz Electric Fields." Paper presented at the DOE/EPRI/NYC Contractors Review, November 1985.

Orr, J. L., et al. 1986. "Determination of Threshold Intensity for Deteciton of $60 \mathrm{~Hz}$ Electric Fields." Paper to be presented at the 8th Annual Meeting of the Bioelectromagnetics Society, June 1986, Madison, Wisconsin (Abstract).

Orr, J. L., and W. R. Rogers. 1985. "Determination of Threshold Intensity for Detection of $60 \mathrm{~Hz}$ Electric Fields." Paper presented at the Seventh Annual Meeting of the Bioelectromagnetics Society, June 1985, San Francisco, California (Abstract).

Phillips R. D., and M. R. Sikov. 1984, "Reproduction and Development of Miniature Pigs and Rats Exposed to $60-\mathrm{Hz}$ Electric Fields. Paper presented at the XXI General Assembly of the International Union of Radio Sciences, August 1984.

Phillips, R. D. 1984. "Biological Effects of Electric Fields: An Overview." Paper presented at the IEEE Biomedical Engineering Society Meeting, Apri 11984.

Phillips, R. D. 1984. "Dosimetry for Extremely Low Frequency Electric Fields." Paper presented at the Environmental Science Seminar, April 1984, Portland State University, Portland Oregon.

Phillips, R. D. 1984. "Effects of 60- Hz Electric Fields on the Function of the Nerovous System." Paper presented at Electromagnetic Waves and Neurobehavioral Function: An International Workshop, August 1984.

Phillips, R. D. 1984. "Neurophysiologic Response to Extremely Low Frequency Electric Fields." Paper presented at the International Workshop on Electromagnetic Waves and Neurobehavioral Function, August 1984.

Rogers, L. E., P. A. Beedlow and J. M. Lee. 1984. "Effects of an 1100-kV Prototype Transmission Line on Tree Growth." Paper presented at the 23rd Annual Hanford Life Sciences Symposium, October 1984.

Rogers, W. R. 1984. "Effects of $60 \mathrm{~Hz}$ Electric Fields on the Behavior of Groups of Nonhuman Primates." Paper presented at Department of Energy Contractors Conference, "Biological Effects from Electric and Magnetic Fields Associated with High Voltage Transmission Lines," November 1984, St. Louis Missouri (Abstract). 
Rogers, W. R. 1985. "Nonhuman Primates" Thresholds for Deteciton of and Escape from $60 \mathrm{~Hz}$ Electric Fields." Paper presented at the Department of Energy Contractors Conference, "Biological Effects from Electric and Magnetic Fields, Air Ions and Ion Currents Associated with High Voltage Transmission Lines," November 1985, Alexandria, Virginia (Abstract).

Rogers, W. R., et al. 1986. "60 Hz Electric Fields do not Serve as a Negative Reinforcer in Nonhuman Primates." Paper to be presented at the 8th Annual Meeting of the Bioelectromagnetics Society, June 1986, Madison, Wisconsin (Abstract).

Rogers, W. R., and J. L. Orr. 1985. "Determination of Threshold Intensity for Avoidance of $60 \mathrm{~Hz}$ Electric Fields by Baboons." Paper presented at the Seventh Annual Meeting of the Bioelectromagnetics Society, June 1985, San Francisco, California (Abstract).

Rommereim, D. N., et al. 1984. "Developmental Effects of Chronic Electric Field Exposure in Rats. Paper presented at the Society for Experimental Biology and Medicine Meeting, October 1984.

Rommereim, D. N., et a1. 1984. "Reproduction and Development in Rats Chronically Exposed to 60-Hz Electric Fields." Paper presented at the 23rd Annual Hanford Life Sciences Symposium, October 1984.

Sagan, P. M., and M. E. Stel1. 1984. "Behavioral Study of Mechanisms for Detection of Electric Fields." Poster presented at the Sixth Annual Meeting of the Bioelectromagnetics Society, Atlanta, Georgia (Abstract J.30).

Sagan, P. M., M. E. Stell and W. R. Adey. 1984. "Behavioral Research on $60 \mathrm{~Hz}$ Electric Fields." Paper presented at the DOE, EPRI, NYSHD Contractor's Review, Saint Louis, Missouri (Abstract).

Sheppard, A. R. 1984. "Environmental Health and the Curious Nature of Biological Interactions with ELF Fields." Paper presented at the Open Symposiun on Interaction of Electromagnetic Fields with Biological Systems, 21 General Assembly of URSI, August/September 1984, Florence, Italy.

Sheppard, A. R. 1984. "Site and Mechanisms for Interaction in Studies of Biological Systems Exposed to ELF Electric or Magnetic Fields." Paper presented at the 23rd Hanford Life Sciences Symposium, Interaction of Biological Systems with Static and ELF Electric and Magnetic Fields, October 1984, Richland, Wasington.

Sheppard, A. R., M. Burton-Sagan and W. R. Adey. 1984. "Influences of Field Strength and Orientation on the Coupling of Extracellular Fields to Aplysia Neurons." Paper presented at the Seventh Annual Meeting of the Bioelectromagnetics Society, June 16-20, 1984, San Francisco, California. 
Sheppard, A. R., et al. 1985. "The Coupling of ELF Electric Fields to Aplysia Pacemaker Cells Depends on Orientation Angle, Field Strength and Extracel1ular Ca++". Paper presented at the DOE, EPRI, NYSDH Contractors Review, Washington, D.C. (Abstract).

Sheppard, A. R., W. F. Pickard and S. M. Bawin. 1984. "Measurements in Aplysia Neurons Detect No Transmembrane Demodulation of Amplitude Modulated 450 MHz Fields." Paper presented at the Sixth Annual Meeting of the Bioelectromagnetics Society, July 1984, Atlanta, Georgia (Abstract).

Stel1, M. E., P. M. Sagan and W. R. Adey. 1985. "Behavioral Effects of $60 \mathrm{~Hz}$ Electric Fields." Paper presented at the DOE, EPRI, NYSHD Contractors Review, Washington, D.C. (Abstract).

Stevens, R, G. 1984. "Electromagnetic Fields and Risk of Leukemia." Paper presented at the DOE/EPRI/NYC Contractors Review, November 1984.

Stevens, R. G. 1985. "Epidemiological Study of the Risk of Breast Cancer and Residential Exposure to Electromagnetic Fields and Light." Paper presented at the DOE/EPRI/NYC Contractors Review, November 1985.

Vasquez, B. J., L. E. Anderson and W. R. Adey. 1985. "Effects of 6D-Hz Electric Fields on Neurochemical Correlates of Circadian Rhythms." Paper presented at the DOE/EPRI/NYC Contractors Review, November 1985.

Vasquez, B. J., L. E. Anderson, and W. R. Adey. 1985. "Effects of $60 \mathrm{~Hz}$ Electric Fields on Neurochemical Correlates of Circadian Rhythms." Paper presented at the DOE, EPRI, NYSOH Contractors Review Meeting, November 1985, washington, D.C.

Vasquez, B. J., P. McNeeley and W. R. Adey. 1984. "Neurochemical Correlates of EMF." Paper presented at the DOE, EPRI, NYSDH Contractors Review Meeting, November 1984, St. Louis, Missouri.

Vasquez, G. J., P. McNeeley and W. R. Adey. 1984. "In Vitro Release of Rat Brain Catecholamines After Exposure to ELF Modulated Fields." Paper presented at the Sixth Annual Meeting of the Bioelectromagnetics Society, July 1984, Atlanta, Georgia.

Wilson, B. W., E. K. Chase and L. E. Anderson. 1985. "Alterations in Pineal Tryptophan Metabolism in Rats Exposed to 60-Hz Electric Fields." Paper presented at the Seventh Annual Meeting of the Bioelectromagnetics Society, June 1985.

Wilson, B. W., E. K. Chess and L. E. Anderson. 1985. "Influence of $6 \mathrm{D}-\mathrm{Hz}$ Electric Fields on Neurochemical Functions in the Rat." Paper presented at the DOE/EPRI/NYC Contractors Review, November 1985. 


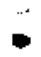


IABLE D.2. External Publications and Conference Presentations Related to DOE/EES Electromagnetic Pulse Research

\section{EXTERNAL PUBLICATIONS}

Barnes, P. R., F. F. Vance, and H. W. Askins, Jr. 1984. Nuclear Electromagnetic Pulse (EMP) and Electric Power Systems. DRNL-6033, Oak Ridge National Laboratory, Oak Ridge, Tennessee.

Barnes, P. R., et a1. 1984. "Corona Effects on EMP Induced Surges in Long Wires." In NEM 1984 Record - Abstracts of Technical Papers. A1 so presented at the Nuclear EMP Meeting, July 2-6, 1984, Baltimore, Maryland.

Barnes, P. R., et al. 1985. "Electromagnetic Pulse and Electric Power Network." IEEE Transactions on Power Apparatus and Systems. PAS-104(6).

Bowe, T. R., et al. 1985. "A Decision Analysis Model to Determine the Appropriate Level of Protection for Small Power Producer/Utility Interconnection." Paper presented at 1985 IEEE PES Summer Meeting, July 1985, Vancouver, Canada. Also in, IEEE 85 SM 327-1.

Engheta, N., K. H. Lee, F. C. Young and R. Aguero. 1985. HEMP-Induced Transients in Transmission and Distribution ( $T$ and $D$ ) Lines. ORNL/Sub84/73986/1. Prepared for Oak Ridge National Laboratory by Kaman Sciences Corporation, Santa Monica, California.

Klien, K. W., P. R. Barnes and H. W. Zaininger. 1985. "Electromagnetic Pulse and the Electric Power Network." IEEE Transactions on Power Apparatus and Systems. PAS-104(6).

Klien, K. W., P. R. Barnes and H. W. Zaininger. 1984. "Electromagnetic Puise and the Electric Power Network." In Proceedings of the 1984 IEEE Suminer Power Meeting. Seattle, Washington.

Lee, K. S. H., F. C. Yang and N. Ergheta. 1983. "Interaction of High-Altitude Electromagnetic Pulse (HEMP) with Transmission and Distributions Lines: An Early-Time Consideration." AFWL Interaction Notes, Note 435. Air Force Weapons Laboratory, Albuquerque, New Mexico.

Legro, J. R., N. C. Abi-Samra and F. M. Tesche. 1985. Study to Assess the Effects of Magnetohydrodynamic Electromagnetic Pulse on Electric Power Systems, Phase I, Final Report, Volume 3. ORNL/Sub-83/43374/1/V3, Oak Ridge National Laboratory, Oak Ridge, Tennessee.

McConnell, B. W., and P. R. Barnes. 1984. "A Preliminary Assessment of the Impact of Electromagnetic Pulse on Electric Power System Insulation." In Proceedings of the Fourth International Symposium on Gaseous Dielectrics. Pergamon Press. 
Modine, F. A., et al. (In Press.) "Laser Fabrication of Electrodes on Zinc Oxide Varistors." Journal of Applied Physics.

Neff, H. P., and D. A. Reed. 1984. "Finitely Conducting Infinitely Long, Cylindrical Wire in the Presence of a Plane Wave (EMP)." AFWL Interaction Notes, Note 436. Air Force Weapons Laboratory, Albuquerque, New Mexico.

Neff, H. P., and D. A. Reed. 1984. "Multiple Parallel Wires Above a Finitely Conducting Plane Earth in the Presence of a Plane Wave (EMP)." AFWL Interac-tion Notes, Note 441. Air Force Weapons Laboratory, Albuquerque, New Mexico.

Neff, H. P., and D. A. Reed. 1984. "Plane Waves (EMP) Incident on a Finitely Conducting Plane Earth with the Magnetic Field Intensity Parallel to the Earth's Surface." AFWL Theoretical Notes, Note 351. Air Force Weapons Laboratory, Albuquerque, New Mexico.

Zaininger, H. W. 1984. Electromagnetic Pulse (EMP) Interaction with Electric Power Systems Final Report. ORNL/Sub/82-47905/1. Prepared for Oak Ridge National Laboratory by Zaininger Engineering Company, San Jose, California.

Zaininger, H. W, and G. M. Jaszewski. 1985. HEMP Interaction with an Electric: Power Distribution Circuit. ORNL/Sub/84-739 $\overline{86 / 1}$. Prepared for Oak Ridge National Laboratory by Zaininger Engineering Company, San Jose, California.

\section{CONFERENCE PRESENTATIONS}

Barnes, P. R. 1984. "Electromagnetic Pulse (EMP) and Its Implications to Electric Power Communications." Paper presented at the IEEE East Tennessee Section Meeting, October 9, 1984, Knoxville, Tennessee.

Barnes, P. R. 1985. Electromagnetic Pulse Program Review Meeting, May 29-30, 1985, Washington, D.C.

Barnes, P. R. 1986. 18th Southeastern Symposium on System Theory, April 7-8, 1986.

Legro, J. R., and T. J. Reed. 1985. "Electromagnetic Pulse and the Electric Power System." Paper presented at the 1985 Electric Utility Engineering Conference, May 12-24, 1985, Pittsburgh, Pennsylvania. 
TABLE 0.3. External Publications and Conference Presentation Related to DOE/EES Normal/Emergency Operating Concepts Research

EXTERNAL PUBLICATIONS

Athans, M. T., et al. 1984. Issues in the Design of a Computer-Aided Systems and Control Analysis and Design Environment (CASCADE). ORNL/TM-9038, Oak Ridge National Laboratory, Oak Ridge, Tennessee.

Barnes, P. R., et al. 1985. "A Modified Unit Commitment and Generation Control for Utilities with Large Wind Generation Penetrations." IEEE Transactions on Power Apparatus and Systems. PAS-104(7).

Behera, A. K., M. A. Pai and P. W. Sauer. 1985. "Analytical Approaches to Determine Critical Clearing Time in Multi-Machine Power System." In Proceedings of the 24th IEEE Conference on Decision and Control, pp. 818-323.

Bower, W., F. B. Brumely, and B. Petterson. 1984. Engineering Evaluation Summary Report for Delta Electronic Control Corporation, Model 61289-32 Uti1ity-Interactive Residential photovoltaic Power Conditioning Subsystem. SAND83-2317, Sandia National Laboratory.

Chow, J. H. 1985. "Natural Modes and Their Stability in Power Systems." In Proceedings of the 24th IEEE Conference on Decision and Control, pp. 799-803.

Chow, J. H., et al. 1985. "Applications of Singular Perturbations Theory to Power System Modeling and Stability Analysis." In Proceedings of 1985 American Control Conference, Pp. 1401-1407. Boston, Massachusetts.

Dugan, R. C., S. A. Thomas and D. T. Rizy. 1984. "Integrating Dispersed Storage and Generation (DSG) with an Automated Distribution System." IEEE Transactions on Power Apparatus and Systems. PAS-103(6).

Dugan, R. C., S. A. Thomas and D. T. Rizy. 1984. "Integrating Dispersed Storage and Generation (DSG) with an Automated Distribution System." IEEE Power Engineering Review. PER-4(6).

Fuchs, E. F., D. U. Roesler and F. S. Alashhab. 1984. "Sensitivity of Home Appliances to Harmonics and Fractional Harmonics of the Power System's Voltages, Part I: Transformers and Induction Machines." In Proceedings of the First International Conference on Harmonics in Power Systems, p. 89. Worcester, Massachusetts.

Fuchs, E. F., D. J. Roesler and K. P. Kovacs. 1984. "Aging of Home Appliances Due to Harmonics of the Power System's Voltage." In Proceedings of the First International Conference on Harmonics in Power Systems, p. 111. Worcester, Massachusetts. 
Fuchs, E. F., D. J. Roesler and K. P. Kovacs. 1984. "Sensitivity of Home Appliances to Harmonics and Fractional Harmonics of the Power Systems's Volt.ages, Part II: Television Sets, Induction Watthour Meters and Universal Machines." In Proceedings of the First International Conference on Harmonics in Power Systems, P. 101. Worcester, Massachusetts.

Fuchs, E. F., L. H. Chang and J. Appelbaum. 1984. "Magnetizing Current, Iron Losses and Forces of Three-Phase Induction Machines at Sinusoidal and Nonsinusoidal Terminal Voltages, Part I: Analysis." IEEE Transactions on Power Apparatus and Systems. PAS-103(11):3303.

Fuchs, E. F., D. J. Roesler and L. H. Chang. 1984. "Magnetizing Current, Iron Losses and Forces of Three-Phase Induction Machines at Sinusoidal and Nonsinusoidal Terminal Voltages, Part II: Results." IEEE Transactions on Power Apparatus and Systems. PAS-103(11):3313.

Huang, G., and L. J. Chiang. 1984. "On-Line Stabilization of the Large HV-ACDC Power System by Using Obsercation Decoupled Reference as a System-Wide Target." IEEE Transactions on Power Apparatus and Systems. pp.789-797.

Phadke, A. G., J. S. Thorp and K. Karimi. 1985. "State Estimation with Phaso" Measurements." Paper presented at the Power Industry Computer Applications Conference, May 1985, San Francisco, California. To be published in Conference Proceedings and in IEEE Transactions on Power Apparatus and Systems.

Rizy, D. T. 1984. Protection and Safety Requirements for Electric Distribution Systems with Dispersed Storage and Generation (DSG) Devices. ORNL/CON143, Oak Ridge National Laboratory, Oak Ridge, Tennessee.

Rizy, D. T. 1985. Report of Foreign Trave1 to 8righton and Leatherhead, United Kingdom. ORNL/FTR-2019, Oak Ridge National Laboratory, Oak Ridge, Tennessee.

Rizy, D. T., W. T. Jewell and J. P. Stoval1. 1984. Operational and Design Considerations for Electric Distribution Systems with Dispersed Storage and Generation (DSG). ORNL/CON-134, Oak Ridge National Laboratory, Oak Ridge, Tennessee.

Rizy, D. T., W. T. Jewell and J. P. Stoval1. 1985. "Operational Design Considerations for Electric Distribution Systems with Dispersed Storage and Generation." Paper presented at the 1985 IEEE Winter Meeting. Also published as IEEE WM 230-8.

Rizy, D. T., and R. C. Dugan. 1984. "Electric Distribution Protection Problems Associated with the Interconnection of Small, Dispersed Generation Devices." IEEE Transactions on Power Apparatus and Systems. PAS-103(6). 
Rizy, D. T., and R. C. Dugan. 1984. "Electric Distribution Protection Problems Associated with the Interconnections of Small, Dispersed Generation Devices." IEEE Power Engineering Society Review. PER-4(6).

Rizy, D. T., and R. C. Dugan. 1985. "Protection of Problems Related to Distribution Systems with Interconnected Dispersed Storage and Generation (DSG) Devices." In Proceedings of the 8th International Conference on Electricity Distribution CIRED, IEEE 250. Brighton Centre, Brighton, United Kingdom.

Rizy, D. T., and W. T. Jewel1. 1984. "Power Quality and Protection of Electric Distribution Systems with Smal1, Dispersed Generation Devices." In Proceedings of the 16th Southeastern Symposium on System Theory. Mississippi State University, Starkville, Mississippi.

Thorp, J. S., A. G. Phadke and K. Karimi. (In Press.) "Real-Time Voltage Phasor Measurements for Static State Estimation." Paper presented at the Winter Power Meetings of IEEE, February 1985, New York. To be published in IEEE Transactions on Power Apparatus and Systems.

Vandenput, A. J., and J.P. Montu. 1984. "Impact of Non-Liner Transformers on the Propagation of Current Harmonics in a Residential Distribution System." In Proceedings of the First International Conference on Harmonics in Power Systems, p. 147, Worcester, Massachusetts.

Van Landingham, H. F., et a 1. 1984. A Non1 inear Observer Applied to State Estimation of a Synchronous Generator. IECON-84, Tokyo, Japan.

\section{CONFERENCE PRESENTATIONS}

Chow, J. H. 1985. "Natural Modes and Their Stability in Power Systems." Paper presented at the 23rd IEEE Conference on Decision and Control, December 1985.

Dugan, R. C., and C. D. Ko. 1984. "Analyzing and Controlling Harmonic Distortion on Distribution Feeders." Paper presented at the International Conference on Harmonics in Power Systems, October 22-23, 1984, Worcester Polytechnic Institute, Worcester, Massachusetts.

Hughes, P. 1984. "Improvements in Variable Speed Electrical Generating System for Wind Turbine Applications." Paper presented at the American Wind Energy Association Conference, August 1984.

Hughes, P. 1985. "Doubly-Fed Variable Speed Generating System Testing." Paper presented at the Fourth ASME Wind Energy Symposium, February 18, 1985.

Rizy, D. T. 1985. "Protection Problems Related to Distribution Systems with Interconnected Dispersed-Storage-Generation Devices." Paper presented at the 8th International Conference on Electricity Distribution (CIRED), May 20-24, 1985, Brighton Centre, Brighton, United Kingdom. 


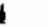


TABLE D.4. External Publications and Presentations in 1984-1985 Related to DOE/EES Failure Mechanisms Research

\section{EXTERNAL PIBBLICATIONS}

Bahder, G., et al. 1982. "Physical Model of Electric Aging and Breakdown of Extruded Polymeric Insulated Power Cables." IEEE Transactions. PAS$101: 1379-1390$.

Bahder, G., et al. 1983. "Electrical Breakdown Characteristics and Testing of High Voltage XLPE and EPR Insulated Cables." IEEE Transactions. PAS102(7):2173-2185.

Hassell, J. A. 1984. "Thermal Analysis--A Tool to Study Aging in Poiyethylene-Insulated, High Voltage Cables." In Proceedings of the 13th North American Thermal Analys is Conference, Sepcember 1984, University of Pennsylvania, Philadelphia, Pennsylvania.

Hassell, J. A. 1985. "Criteria and Practical Applications for Making Service Life Predictions." Paper presented at the 1985 National Meeting of the American Chemical Society. A1so in "Proceedings of the ACS Division of Polymeric Materials." Science and Engineering 52, Spring, 1985 (Abstract).

Hassell, J. A., G. R. Hattery and M. M. Epstein. 1985. "Thermal Analys is of Semi-Crystalline Dielectrics." In Proceedings of the 17th Electrical/Electronics Insulation Conference, September 1985, Boston, Massachusetts (Abstract).

Hassell, J. A., and V. D. McGinniss. 1985. "Chemiluminescence--A Highly Sensitive Method for Determining Chemical Changes in Polymeric Materiais." Paper presented at the 1985 National Meeting of the American Chemical Society. Also in "Proceedings of the ACS Division of Polymeric Materials." Science and Engineering 52, Spring, 1985 (Abstract).

Mangaraj, D., et al. 1984. "Functional Analysis of Antioxidant in Thermoplastic Cable Insulations." Paper presented at the 1984 Conference on Electrical Insulation and Dielectric Phenomena, October 1984. Published in the 1984 Annual Report.

Master, M. J., and M. A. Uman. 1984. "Lightning Induced Voltages on Power Systems: Theory." IEEE Transactions on Power Apparatus and Systems. PAS-103:2502-2518.

Master, M. J., et al. 1984. "Lightning Induced Voltages on Power Lines: Experiment." IEEE Transactions on Power Apparatus and Systems. PAS-103:2519-2529.

McClintock, F. A., et al. 1984. Assessing Expired Fatigue Life in Large Turbine Shafts. ORNL/Sub/83-9062/1, Oak Ridge National Laboratory, Oak Ridge, Tennessee. 
Richter, E. 1984. Permanent Magnet Motors. ORNL/Sub/82-17452/1, Oak Ridge National Laboratory, Oak Ridge, Tennessee.

Thomas, R. E. 1985. "Life Prediction for Cable Insulation Material Based on Weibull Accelerated Testing Without Failures." IEEE Transactions in Electrical Insulation. E1-20(1).

Thompson, E. M., et a1. 1985. "Horizontal Electric Fields from Lightning Return Strokes." In Proceedings of the International Aerospace and Ground Conference of Lightning and Static Electricity, D. T. Rizy, Technical Monitor. Paris, France.

\section{CONFERENCE PRESENTATIONS}

American Chemical Society. 1985. "Workshop on Service Life of Poymers," V. 0. McGuinniss, Chairman; M. M. Epstein, Cochairman, moderator. Paper presented at the American Chemical Society National Meeting, May 5, 1985.

Epstein, and G. B. Gaines. 1983. "Age-Induced Changes in Cable Materials." Paper presented at the EPRI Workshop--Accelerated Aging of Cables, December $14.16,1983$.

G. B. Gaines. 1984. "Physical Theories of Dielectric Materials and Interracial Phenomena." Paper presented ath the 00E/EES Workshop--Research and Development on New Dielectric Materials for Electric Utility Equipment, June 20-21, 1984. 
TABLE D.5. External Publications and Conference Presentations Related to DOE/EES HVDC Research

EXTERNAL PUBLICATIONS

Biggs, R. B., and W. T. Jewell. 19--. Summary of Multiterminal High-Voltage Di rect Current Transmission Technology. ORNL/TM-8724, Oak Ridge National Laboratory, Oak Ridge, Tennessee.

Bowles, J. P., et al. 1985. Comparison of Cost and Benefits for DC and AC Transmission. ORNL-6024, Oak Ridge National Laboratory, Oak Ridge, Tennessee.

Dale, S. J., et al. 1983. "Dielectric Design and Test of 1200-kV SemiFlexible $\mathrm{SF}_{6}$ Insulated Transmission Line." IEEE. PAS-102:400.

Heyer, S. V., et al. 1983. Evaluation of Underground DC Transmission Systems, Final Report. Prepared for Oak Ridge National Laboratory, Oak Ridge Tennessee by the Engineering and Research Department, Philadelphia Electric Company, Philadelphia, Pennsylvania.

Zorpette, Glen. 1985. "HVDC: Wheeling Lots of Power." IEEE Spectrum.

\section{CONFERENCE PRESENTATIONS}

Birdwel1, J. D., et a1. 1985. "Expert Systems Techniques in a Computer-Based Control System Analys is and Design Environment." Paper presented at the 3rd IFAC Symposium on Computer-Aided Design in Control and Engineering Systems, JuTy 31- August 1, 1985, Lyngby, Denmark.

Birdwe]1, J. D., et al. 1985. "CASCADE: Experiments in the Development of Knowledge-Based Computer-Ajded Systems and Control Analysis and Design Environments." Paper presented at the IEEE Control Systems Society 2nd Symposium on Computer-Aided Control Systems Design (CACSD), March 13-15, 1985, Santa Barbara, California.

Cooper, J. H., W. H. South and J. F. Shimshock. 1984. "Field Test Experience and Diagnostic Techniques on 1200-kV Gas Insulated Substation Components." Paper presented at the International Conference on Large High Voltage Electric Systems, August 29 to September 6, 1984.

Gnadt, P. A., and J. P. Stova11. 1984. D0E/EES Workshop on Research and Development of HVDC Power Systems Components, October 9-10, 1984, Knoxville, Tennessee. 
TABLE D.6 External Publications and Conference Presentations Related to DOE/EES Automation/Processing Research

EXTERNAL PUBLICATIONS

Chiang, H. O., M. W. Hirsch and F. F. Wu. (In Press.) "Stability Regions of Non-liner Autonomous Oynamical Systems." IEEE Transactions Circuits and Systems.

Mckinley, J. F. 1985. Economics of Distribution Automation. Energy Division, Oak Ridge National Laboratory, Oak Ridge, Tennessee.

Patten, J. B., J. S. Lawler and K. F. McKinley. 1984. Designing Distribution Automation Application Software. Energy Division, Oak Ridge National Laboratory, Oak Ridge, Tennessee.

Purucker, S. L., et al. 1985. Automation and Control of a Distribution Power System. Energy Division, Oak Ridge National Laboratory, Oak Ridge, Tennessee.

Purucker, S. L., et al. 1985. "Feeder Automation Designs Installing an Integrated Distribution Control System." In Proceedings of the IEEE Power Engineering Society Winter Meeting.

Purucker, S. L., et al. 1985. "Feeder Automation Oesigns for Installing an Integrated Distribution Control System." IEEE Transactions on Power Apparatus and Systems. PAS-104(10).

Purucker, S. L., et al. 1985. "The Design of an Integrated Distribution Control System." IEEE Transactions on Power Apparatus and Systems. PAS-104(3).

Purucker, S. L., et al. 1985. Athens Automation and Control Experiment Project Review Meeting, Dallas, Texas, December 5-6, 1984. ORNL/TM-9758, 0ak Ridge National Laboratory, Oak Ridge, Tennessee.

Reed, J. H. 1984. Marketing a Direct Load Control Program. Energy Division, Oak Ridge National Laboratory, Oak Ridge Tennessee.

Reed, J. H., et al. 1985. Test Plan for the Load Control Experiments, Athens Aut omation and Control Experiment. ORNL/TM-9796, Oak Ridge NationaT Laboratory, Oak Ridge, Tennessee.

Wetherington, G. R., et al. 1985. "Use of a General-Purpose Development System in Support of a Large-Scale Electrical Distribution Control System." In Proceedings of the Internation Load Management Conference and Expostion. Chicago, ITtinois. 


\section{CONFERENCE PRESENTATIONS}

Power Systems Technology Program Participants. 1985. American Public Power Association Workshop on the Athens Automation and Control Experiment, June 24-26, 1985, Knoxvilie, Tennessee.

Power Systems Technology Program Participants. 1985. Athens Automation and Control Experiment Review Meeting, December 4-6, 1985, Knoxville, Tennessee.

Purucker, S. L. 1984. "Automation and Control of a Distribution Power System." Paper presented at the IEEE Control of Power Systems Conference, March 20-21, 1984, Oklahoma City, Ok1ahoma.

Purucker, S. L. 1984. Meeting of the Advisory Committee for the Athens Automation and Control Experiment, April 17, 1984, Knoxville, Tennessee.

Purucker, S. L. 1985. "AACE Distribution Automation." Paper presented at the Edison Electric Institute System Planning Committee Meeting, June 5, 1985, Kansas City, Kansas.

Purucker, S. L. 1985. "Distribution Automation." Paper presented at the American Public Power Assocation Workshop on Distribution Automation and Control, June 24-26, 1985, Knoxvilie, Tennessee.

Purucker, S. L., and K. F. MCKinley. 1985. "AACE Status and Baltimore Gas and Electric (BG\&E) Involvement." Paper presented at BG\&E, September 6, 1985, Baltimore, Maryland.

Reddoch, T.W. 1984. "Automation and Control of a Distribution Power System." Paper presented at the Energy Technology Conference and Exposition, March 21-23, 1984, Washington, D.C.

Reddoch, T. W. 1984. "Telephone, Powerline Carrier, and Radio." Paper presented at the American Public Power Association Workshop, March 27-28, 1984, Toronto, Canada.

Rizy, D. T. 1984. "Power Quality and Protection of Electric Distribution Systems with Sma11, Dispersed Generation Devices." Paper presented at the 16th Southeastern Symposium on System Theory, Marcy 27, 1984, Mississippi State University, Starksville, Mississippi.

Rizy, D. T. 1984. "Utility Interconnection with Dispersed Generating Sources." Paper presented at the 1984 IEEE/PES Summer Meeting, July 16-20, 1984, Seattle, Washington.

Rizy, D. T. 1985. "Voltage and Var Control Experiments." Paper presented at the American Public Power Association Workshop on Distribution Automation and Control, June 24-26, 1985, Knoxville, Tennessee. 
Rizy, D. T., organizer. 1985. Eighth International Conference on Electricity Distribution, May 18-25, 1985, Brighton, United Kingdom.

Stevens, R. A., D. T. Rizy, S. L. Purucker. 1986. "Performance of Conventional Power Flow Routines for Real-Time Distribution Automation Applications." Paper presented at the 1986 Souteastern Symposium on System Theory, April 1986, Knoxville, Tennessee.

Zrida, J., F. C. Chow and J. D. Birdwell. 1986. "Analysis of Household Load Data." Paper presented at the 1986 Southeastern Symposium on System Theory, April 1986, University of Tennessee, Knoxville, Tennessee.

Zrida, J., F. C. Chow and J. D. Birdwe11. 1986. "Utility Substation Data Modeling." Paper presented at the 1986 Southeastern Symposium on Systern Theory, April 1986, University of Tennessee, Knoxville, Tennessee. 
TABLE 0.7. External Publications and Conference Presentations Related to DOE/EES New Materials Research

EXTERNAL PUBLICATIONS

Bigg, D. M., E. G. Smith, M. M. Epstein and R. J. Fiorentino. 1984. "Mechanical Property Enhancement of Semi-Crystalline Polymers by Solid-State Rolling." Journal of Engineering for Industry, May 1984.

Bigg, D. M., E. G. Smith, R. J. Fiorentino and M. M. Epstein. 1984. "Properties of Uniaxially Oriented High-Density Polyethylene Tape Produced by Solid-State Rolling." Polymer Process Engineering.

Bigg, D. M., E. G. Smith, R. J. Fiorentino and M. M. Epstein. 1984. "SolidState Rolling of Linear Polyolefins." Paper presented at the 9th International Congress on Rheology, Mexico City, 1984. Also in Conference Proceedings.

Boutdin, D. W., et al. 1984. "A Current Assessment of the Potential of Dielectric Gas Mixtures for Industrial Applications." Gaseous Dielectrics IV, eds. L. G. Christophorou and M. 0. Pace, pp. 204-21

Canwright, G. S., and D. M. Kroeger. 1985. "Effects of Microadditions of Cerium on the Magnetic Properties of $\mathrm{FE}_{80} \mathrm{~B}_{16} \mathrm{SI}_{2} \mathrm{C}_{2}$ Metallic Glass." Paper submitted to IEEE Transactions Magnetics.

Christophorou, L. G. and M. 0. Pace, eds. 1984. Gaseous Dielectrics IV. Pergamon Press, New York.

Christophorou, L. G., et al. 1984. "Recent Advances in Gaseous Dielectrics at Oak Ridge National Laboratory." In Conference Record of the 1984 IEEE International Symposium on Electrical Insutation, pp. 122-136.. IEEE 83CH19646E I, Beauregard Press, Ot towa, Canada.

Christophorou, L. G., et al. 1984. "Recent Advances in Gaseous Dielectrics at Oak Ridge National Laboratory." IEEE Transactions Electr. Insul. EI-19:550556 .

Christophorou, L. G., et a1. 1983. "Isotope Dependence of the Breakdown Strength of Gasses." Journal of Applied Physics. 54:3098-3100.

Christophorou, L. G., et al. 1983. "Basic Studies of Bases for DiffuseDischarge Switching Applications." In Proceedings of the U.S.-F.R.G. Joint Seminar on Externally Controlled Diffuse Discharges, pp. 104-117. Texas Tech. University, Lubbock, Texas.

Christophorou, L. G., et al. 1983. "Basic Studies of Bases for DiffuseDischarge Switching Applications." In Proceedings of the 4th IEEE Pulsed Power Conference, eds. T. H. Mart in and M. R. Rose, pp. 702-708. The Texas Tech. Press, Lubbock, Texas. 
Christophorou, L. G., and S. J. Dale. (In Press.) "Dielectric Gases." In Encyclopedia of Physical Science and Technology, ed. R.A. Meyers. Academic Press, New York.

Dale, S. J. 1985. "Materials Research." Papers presented at a Workshop on Electric Energy Systems, pp. 11-36. National Academy Press, Washington, D.C.

Forsyth, E. B. 1985. The Development of Synthetic Tape Insulation for Both Cryogenic and Ambient Temperature Power Cables. BNL 36690, Tokyo, Japan.

Griffin, G. D., et a1. (In Press.) "Cytotoxic Activity of Spark-Decomposed Sulfur Hexaflouride and Analysis of Cytotoxic Contributions of Individual Spark-Decomposed Products." Toxicology and Environmental Chemistry.

Griffin, G. D., et al. 1984. "Decomposition of Sparked SF 6 and Cytotoxity of $\mathrm{SF}_{6}$ Decomposition Products." Gaseous Dielectrics IV, eds. L. G. Christophorou and M. 0. Pace, pp. 261-272. Pergamon Press, New York.

Hebner, R. E. 1984. "High-Speed Data Systems for Pulsed Power Applications." In Proceedings of the 5th IEEE Pulsed Power Conference.

Hunter, S. R., J. G. Carter, L. G. Christopherou and V. K. Lakdawala. 1984. "Transport Properties and Dielectric Strengths of Gas Mixtures for Use in Diffuse-Discharge Opening Switches." Gaseous Dielectrics IV, eds. L. G. Christophorou and M. 0. Pace, pp. 224- 237 . Pergamon Press, New York.

Hunter, S. R., and L. G. Christophorou. (In Press.) "Pressure-Dependent Elec.tron Attachment and Breakdown Strengths of Unjtary Gases and Synergism of Binary Gas Mixtures: A Relationship." Journal of Applied Physics.

Hunter, S. R., and L. G. Christophorou. 1984. "Electron Attachment to the Perfluoroalkanes $n-C_{N} F_{2 N+2}(N=1-6)$ Using High Pressure Swarm Techniques." J.Chem. Phys. $80: 6150-6154$.

Hunter, S. R., and L. G. Christophorou. 1984. "Pressure-Dependent Electron Attachment and Breakdown Strengths in Unitary Gases, and Synergism of Binary Gas Mixtures: A Relationship." Gaseous Dielectrics IV, eds. L. G. Christophorou and M. 0. Pace, pp. 115-126. Pergamon Press, New York.

James, D. R., et al. 1984. A Current Assessment of Research on Insulating Gas Mixtures and Their Potential for Industrial Applications. ORNL/TM-9017, 0ax Ridge Nationa Laboratory, Oak Ridge Tennessee.

Kroeger, D. M., et a1. 1985. "A Study of the Mechanism for Annealing Embrittlement of an Iron-Base Metallic Glass." In Proceedings of the 5th International Conference on Rapidly Quenched Metals, eds. S. Stteb and H. Warlimont, p. 1369. Elsevier Science Publishers. 
Lauf, R. J., R. K. Williams and F. T. Greenwald. 1985. High-Field Zno Varistors: Microstructures and Properties. ORNL/TM-9378, Oak Ridge National Laboratory, Oak Ridge, Tennessee.

McCorkle, D. L., A. A. Christodoulides and L. G. Christophorou. 1984. "Electron Attachment to Halocarbons of Interest in Gaseous Oielectrics." Gaseous Dielectrics IV, eds. L. G. Christophorou and M. 0. Pace, pp. 12-22. Pergamon Press, New York.

McCoy, H. E. 1985. Evaluation of Polymer Films for Electrical Insulation. ORNL-6134, Oak Ridge National Laboratory, Oak Ridge, Tennessee.

McCoy, H. E., and C. R. Brinkman. 1985. "Evaluation of Several Polymer Films for Use as Electrical Insulators." In Proceedings of the 1985 Electrical/Electronics Insulation Exposition. Boston, Massachusetts.

Modine, F. A., et al. (In Press.) "Laser Fabrication of Electrodes on Zinc Oxide Varistors." Journal of Applied Physics.

Nakanishi, $K_{*}$, et al. 1984. "The Pressure Dependence of the Dielectric Strength of $\mathrm{SO}_{2}$ and $n-\mathrm{C}_{4} \mathrm{~F}_{10^{*}}$ " J. Phys. 0. 17:L73-76.

Pace, M. 0., J. L. Adcock and L. G. Christophorou. 1984. "Particle Contamination in Gas-Insulation Systems: New Control Methods and Mixtures." Gaseous Dielectrics IV, eds. L. G. Christophorou and M. 0. Pace, Pp. 377-384. Pergamon Press, New York.

Phillipp, H., G. 0. Mahan and L. M. Levinson. 1984. Advanced Metal Oxide Varistor Concepts. ORNL/Sub/84-17457/1, Oak Ridge National Laboratory, 0ak Ridge, Tennessee.

Rodriquez, A., et al. 1985. "Effect of Insulator Surface Temperature on the Flashover Voltage of Outdoor Insulators." In Proceedings of the Electronic and Electrical Insulation Conference. Boston, Massachusetts.

Sauers, I. (In Press.) "Sensitive Detection of By-Products Formed in Electrically 0ischarged Sulfur Hexaflouride." IEEE Transactions on Electrical Insulation.

Sauers, I., et al. (In Press.) "Neutral Decomposition Products in Spark Breakdown of $\mathrm{SF}_{6} \cdot$ " IEEE Transactions on Electric Insulation.

Sauers, I., et al. 1984. Spark Decomposition of SF ; Toxity of By-Products. ORNL/TM-9062, Dak Ridge National Laboratory, Dak Ridge, Tennessee.

Sauers, I., L. G. Christophorou and S. M. Spyrou. 1984. "Negative Ion Formation in SF 6 Spark By-Products." Gaseous Dielectrics IV, eds. L. G. Christophorou and M. 0. Pace, pp. 292-304. Pergamon Press, New York. 
Spyrou, S. M., S. R. Hunter and L. G. Christophorou. 1984. "Studies of Negative Ion Formation in Fluoroethers and Fluorosulphides Using Low-Energy ( $<10 \mathrm{eV}$ ) Electron Beam and Electron Swarm Techniques." Journal of Chemical Physics 81:4481-4493.

Spyrou, S. M., and L. G. Christophorou. (In Press.) "Effect of Temperature on

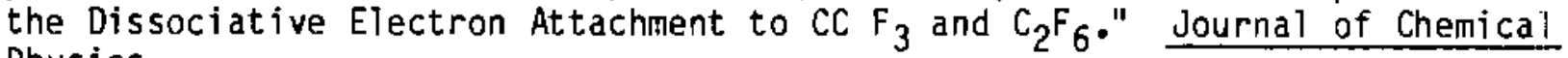
Physics.

\section{CONFERENCE PRESENTATIONS}

Cheng, T. C., and L. F. Hunt. 1985. "Effect of the Insulator Surface Tempera-ture on the Flashover Voltage of Outdoor Insulators." Paper presented at the 17th IEEE Electrical/Electronic Insulation Conference, October 1985, Boston, Massachusetts.

Dale, S. D. 1985. "DOE Dielectric Materials." Paper presented to the New York Energy Committee.

Dale, S. D., organizer. 1985. EPRI Workshop on HVDC Insulators, University 0* Southern California.

Dale, S. J. 1984. "New Transmission Cable Designs." Paper presented at the DOE/EES Research and Development of HVDC Power Systems and Components Workshop, October 10, 1984, Knoxville, Tennessee.

Dale, S. J. 1985. "Research and Development of Dielectric Materials - A U.S. Department of Energy Long Range Program Plan." Paper presented at the Norwegian Research Institute of Electricity Supply, September 4, 1985, Trondheim, Norway.

Dale, S. J., organizer. 1984. Dielectrics Workshop for Five-Year DOE Research and Development Program, June 20-21, 1984, Knoxville, Tennessee.

Lauf, R. J., and T. W. Reddoch, organizers. 1984. Zno Technology Transfer Seminar, January 11-12, 1984, Oak Ridge, Tennessee.

Rodrigues, A. 1984. "Electronic and Electrical Insulation," lst Award for paper. Conference sponsored by National Electrical Manufacturers Association. 
TABLE D.8. External Publications and Conference Presentations Related EXTERNAL PUBLICATIONS to DOE/EES Superconducting Technologies Research

Forsyth, E. B. 1984. The $60 \mathrm{~Hz}$ and Cryogenic Performance of Superconductive Power Transmission Cable Rated for 333 MVA Per Phase. BNL-35397.

Forsyth, E. B. 1984. "The $60 \mathrm{~Hz}$ Performance of Superconducting Power Transmission Cables Rated for 333 MVA Per Phase." IEEE Trans. on Power Apparatus and Systems, PAS-103(8):2023, August 1984 .

Forsyth, E. B. 1984. "The Brookhaven Superconducting Underground Power Transmission System." Electronics and Power, May 1984.

Forsyth, E. B. 1984. "Superconducting Power Transmission Cables." Encyclopedia of Physical Science and Technology.

Forsyth, E. B. 1985. The Development of Superconducting Power Transmissions Technology. BNL $3674 \overline{3}$.

Forsyth, E. B., and R. A. Thomas. 1985. "Operational Test Results of a Prototype Superconducting Power System and Their Extrapolation to the Performance of a Large System." IEEE Trans, on Power Delivery, January 1986.

Schaur, F. 1982. Theory of Losses and Loss Measurements of Superconducting Power Cables Consistig of Hellcially Wound Conductor Tapes. NTIS: DE83009874, BNL51644, Brookhaven National Laboratory, Upton, New York.

Schaur, F. (In Press.) "Theory of Losses and Loss Measurements of Superconducting Power Cables Consisting of Helicially Wound Conduct or Tapes." In Proceedings of the International Conference on Cryogenic Materials.

Thomas, R. A. 1984. Operational Characteristics of a 1000 MVA Superconducting Power Transmission System. BNL 35210.

Thomas, R. A. 1985. "Operational Characteristics of a 1000 MVA Superconduct. ing Power Transmission." IEEE Trans. on Magnetics, March 1985.

\section{CONFERENCE PRESENTATIONS}

Forsyth, E. B. 1985. "The Development of Synthetic Tape Insulation for Both Cryogenic and Ambient Temperature Power Cables." Paper presented at the 18th Symposium on Electrical Insulating Materials, October 1, 19B5, Tokyo, Japan.

Forsyth, E. B., and R. A. Thomas. 1985. "Operational Test Results of a Prototype Superconducting Power System and Their Extrapolation to the Performance of a Large System." Paper presented at IEEE Summer Meeting. 
TABLE 0.9. External Publications and Conference Presentations Related to DOE/EES BEST Research

EXTERNAL PUBLICATIONS

Pivec, A., B. M. Radimer and E. A. Hyman. 1985. Utility Operation of Battery Energy Storage at the BEST Facility. IEEE 85 SM 434-6.

Pivec, A., and M. F. Strickland. 1985. "Energy Storage and the BEST Facil-

ity." Modern Power Systems.

Public Service Electric and Gas. 1984. Battery Energy Storage Test (BEST) Facility: Third Progress Report. EPRI EM-2995, ETectric Power Research Institute.

Public Service Electric and Gas. 1984. Operation of the Baseline BEST Facility in Utility and Customer-Side Operations. PSE\&G RD84-2, Public Service Electric and Gas.

Public Service Electric and Gas. 1984. Thermal Testing of the 1.8 Mwh Facility Shakedown Battery. PSE\&G RD84-1, Public Service Electric and Gas.

Public Service Electric and Gas. 1985. Baseline Cycle Testing of a $500 \mathrm{kWh}$ Zinc Chloride Battery at the BEST Facility. EPRI EM-3836, Electric Power Research.

Zorpette, G. 1984. "Advanced Batteries for Utility Use." IEEE Spectrum.

\section{CONFERENCE PRESENTATIONS}

Pivec, A. 1983. "Energy Storage and the BEST Facility." Paper presented at the Energy Storage Conference, December 12, 1983, Royal Swedish Academy of Engineering Sciences.

Pivec, A. 1985. "Applications Testing of Batteries for Utility Load Leveling and Customer Application." Paper presented at the International Workshop on Battery Testing USDOE and FRG Ministry for Research and Technology, September 30, 1985.

Pivec, A., B. M. Radminer and E. A. Hyman. 1985. "Utility Operation of Battery Energy Storage at the BEST Facility. Paper presented at the Power Engineering Society Summer Meeting, July 18, 1985.

Pivec, A., and E. A. Hyman. 1984. "BEST Facility Progress Report." Paper presented at the DOE Battery Contractor's Conference, June 26, 1984.

Radimer, B. M., and E. A. Hyman. 1985. "BEST Facility Progress Report." Paper presented at DOE Battery Contractor's Conference, November 19-20, 1985. 
Sobieski, D. 1984. "Economic Aspects of Providing Spinning Reserve by Battery Energy Storage." Paper presented at the International Symposium and Workshop on the Dynamic Benefits of Energy Storage Plant Operation, May 1984, Boston, Massachusetts. 
TABLE 0.10. Externa1 Publications and Conference Presentations Related
to DOE/EES Hawai i Deep Water Cable Research In 1984-1985

EXTERNAL PUBLICATIONS

Connell, R. L. 1985. "Hawaii Deep Water Cable Program." Submitted for inclusion in Proceedings of National Research Council April 1985 Workshop. Washington, D.C.

Eaton, Or. R., III, and G. 0. Lesperance. 1985. "Hawaji's Geothermal and Deep Water Cable Programs." In Proceedings of the 9th Annual International Symposium on Geothermal Energy. Kona, Hawaii.

Walldorf, S. P., G. N. Okura and G. A. Chapman. (In Press.) "Cable Selection Methodology for Deep water Power Transmission Systems Applications." IEEE. 
1 
DISTRIBUTION

No. of

Copies

OFFSITE

K. W. Klien

CE-32

U.S. Department of Energy

1000 Independence Ave

Washington, D.C. 20585

R. Eaton

$C E-32$

U.S. Department of Energy

1000 Independence Ave

Washington, DC 20585

3. E. Quinn

CE-32

U.S. Department of Energy 1000 Independence Ave

Washington, DC 20585

W. Wisecup

$W /$ L Associates Ltd.

600 South Fredrick Avenue

Gaithersburg, MD 20877

30 DOE Technical Information Center

P. R. Barnes

Oak Ridge National Laboratory

P.0. Box $X$

Oak Ridge, TN 37831

T. Rizy

Oak Ridge National Laboratory

P.0. Box $X$

Oak Ridge, TN 37831

T. Reddock

Electrotek Concepts, Inc.

912 South Gay Street

Suite 1500

Knoxville, TN 37902
No. of

Copies

M. Epstein

Battelle-Columbus Laboratories

505 King Avenue

Columbus, $\mathrm{OH} 43201$

J. Stovall

Oak Ridge National Laboratory

P.0. Box $X$

Oak Ridge, TN 37381

S. J. Dale

Oak Ridge National Laboratory

P.0. Box $X$

Oak Ridge, TN 37831

E. Forsyth

Brookhaven National Laboratory

Upton, NY 11973

S. Purucker

Oak Ridge National Laboratory

P.0. Box $X$

Oak Ridge, TN 37831

A. Pivec

Public Service Electric and Gas

P.0. Box 570

Newark, NJ 07101

ONSITE

DOE Richland Operations

J. J. Sutey

27 Pacific Northwest Laboratory

R. C. Adams

L. E. Anderson

J. W. Currie

L. J. Davis

J. G. DeSteese

L. L. Fassbender 
No. of

Copies

B. J. Harrer

J. W. Hurwitch

C. H. Imhoff

B. L. Mohler

R. M. Smith (10)

Publishing Coordination MA (2)

Technical Information (5) 